\title{
APPLICABILITY OF
}

\section{AMBIENT TOXICITY TESTING}

TO NATIONAL OR REGIONAL

\section{WATER-QUALITY ASSESSMENT}

U. S. GEOLOGIGAL SURVEY

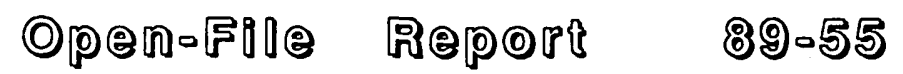


0

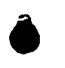

-

0

0

-

0 
APPLICABILITY OF AMBIENT TOXICITY TESTING TO NATIONAL OR REGIONAL WATER-QUALITY ASSESSMENT

U.S. GEOLOGICAL SURVEY

Open-File Report 89-55

SEAL 
APPLICABILITY OF AMBIENT TOXICITY TESTING TO NATIONAL

OR REGIONAL WATER-QUALITY ASSESSMENT

By John F. Elder

U.S. GEOLOGICAL SURVEY

Open-File Report 89-55

SEAL

Madison, Wisconsin

1989 


\author{
DEPARTMENT OF THE INTERIOR \\ MANUEL LUJAN, JR., Secretary \\ U.S. GEOLOGICAL SURVEY \\ Dallas L. Peck, Director
}




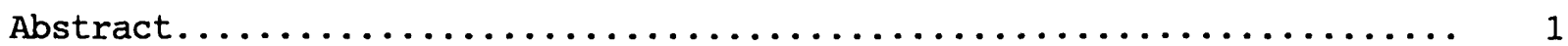

Introduction. ..................................

Need for biological methods in water-quality assessment......... 3

Difficulties of biological methods in water-quality assessment... 4

Purpose and scope............................... 4

Acknowledgments ............................... 6

Benefits and limitations of toxicity testing ................

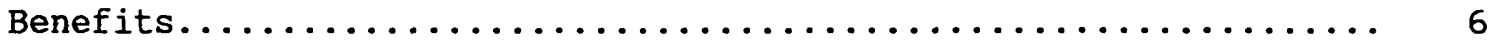

Limitations.................................. 7

Special considerations for large-scale toxicity testing......... 9

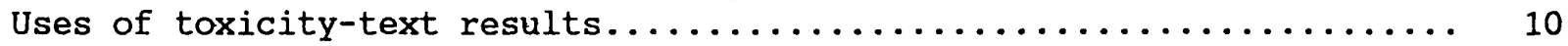

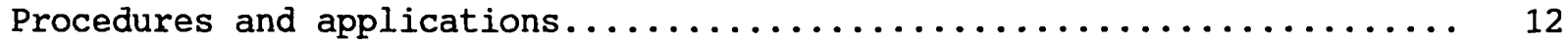

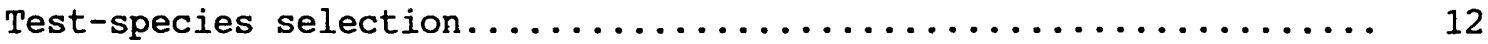

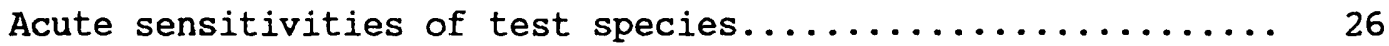

Overview of test-species selection................ 36

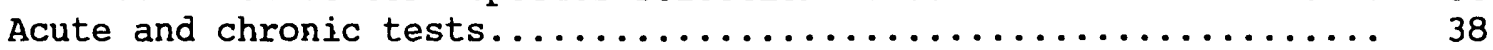

Design of test enclosure.......................... 40

Multispecies tests.............................. 40

Microcosm approach......................... 41

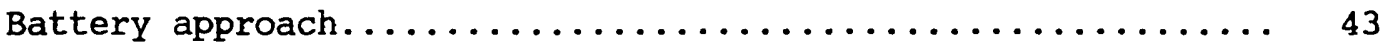

Sediment toxicity tests............................. 44

Biochemical effects.............................. 47

Overview of test type differences...................... 50

Field and interlaboratory verification of toxicity tests..........53

Alternatives to laboratory toxicity testing.................. 57

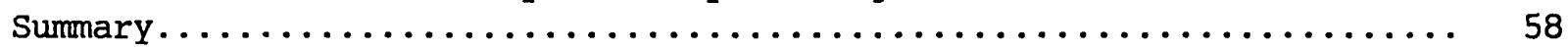

References cited..................................... 61

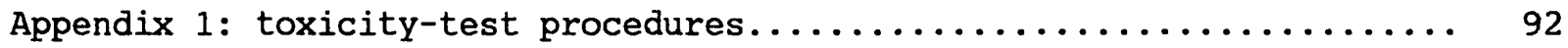

Figure 1. Diagram showing taxonomic lineages of commonly used freshwater toxicity-test species.................

2. Graph showing 50-percent lethal concentration and maxima and median concentration data for copper, cadmium, zinc, mercury, and lead in water from five selected U.S. Geological Survey water-quality-monitoring sites and

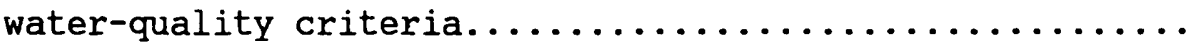

3. Diagram showing general scheme for sequential toxicity screening.............................. 
TABLES

Page

Table 1. Some possible uses of toxicity tests, in order of the

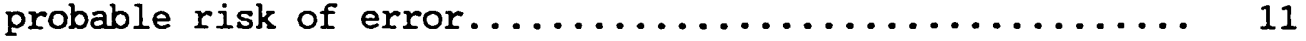

2. List of criteria for species selection............... 14

3. Identification and characterization of some floral and faunal species frequently used in aquatic toxicity-testing procedures.................... 16

4. General characteristics of flora and fauna used in toxicity testing........................... 20

5-10. Evaluation of commonly used toxicity-test species with respect to selection criteria listed in table 1:

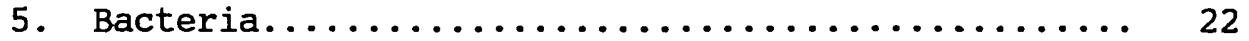

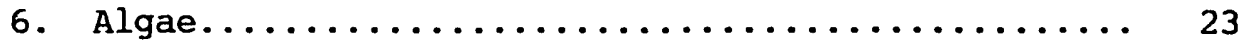

7. Daphnia magna........................ 23

8. Cladocerans, excluding Daphnia magna.......... 24

9. Pimephales promelas.................... 24

10. Fish, excluding Pimephales promelas............ 25

11-14. Acute toxicities of selected organic compounds to various test species:

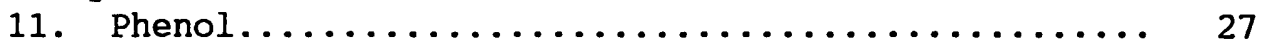

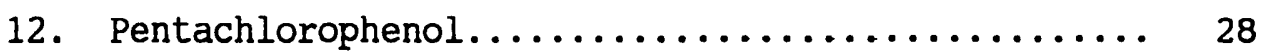

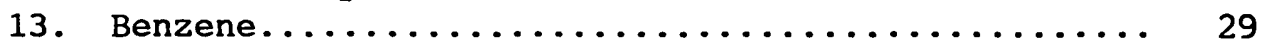

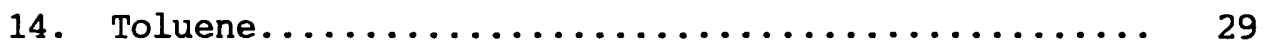

15-19. Acute toxicities of selected metals to various test species:

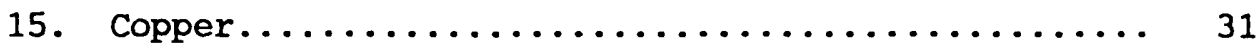

16. Cadmium............................... 32

17. Zinc................................. 33

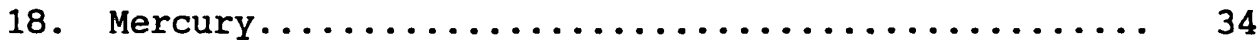

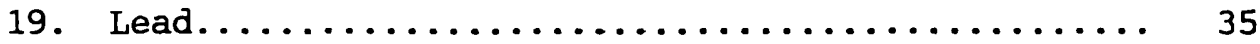

20. Reasons for and against use of different

toxicity-test procedures..................... 50

21. Comparisons of different types of toxicity tests......... 55

Appendix Table 1. Partial list of publications containing detailed method descriptions for species-specific toxicity tests.........

Appendix Table 2. Partial list of references with detailed method descriptions for different toxicity-test types............... 
APPLICABILITY OF AMBIENT TOXICITY TESTING TO NATIONAL

OR REGIONAL WATER-QUALITY ASSESSMENT

by John F. Elder

\begin{abstract}
Comprehensive assessment of the quality of natural waters requires a multifaceted approach. Descriptions of existing conditions may be achieved by various kinds of chemical and hydrologic analyses, whereas information about the effects of such conditions on living organisms depends on biological monitoring. Toxicity testing is one type of biological monitoring that may be used to identify possible effects of toxic contaminants.

Based on experimentation designed to monitor responses of organisms to environmental stresses, toxicity testing may have diverse purposes in waterquality assessments. These purposes may include identification that warrant further study because of poor water quality or unusual ecological features, verification of other types of monitoring, or assessment of contaminant effects on aquatic communities. Toxicity-test results are most effective when used as a complement to chemical analyses, hydrologic measurements, and other biological monitoring. However, all toxicity-testing procedures have certain limitations that must be considered in developing the methodology and applications of toxicity testing in any large-scale water-quality-assessment program.
\end{abstract}

A wide variety of toxicity-test methods have been developed to fulfill the needs of diverse applications. The methods differ primarily in the selections made relative to four characteristics: (1) test species, (2) endpoints (acute or chronic), (3) test enclosure type, and (4) test substance (toxicant) that functions as the environmental stress.

Toxicity-test approaches vary in their capacity to meet the needs of large-scale assessments of existing water quality. Ambient testing, whereby the test organism is exposed to naturally occurring substances that contain toxicant mixtures in an organic or inorganic matrix, is more likely to meet these needs than are the procedures that call for exposure of the test organisms to known concentrations of a single toxicant. However, meaningful interpretation of ambient test results depend on the existence of accompanying chemical analysis of the ambient media. The ambient test substance may be water or sediments. Sediment tests have had limited application, but they are useful because of the fact that most toxicants tend to accumulate in sediments, and many test species either inhabit the sediments or are in frequent contact with them. Biochemical testing methods, which have been developing rapidly in recent years, are likely to be among the most useful procedures for large-scale water-quality assessments. They are relatively rapid and simple, and more importantly, they focus on biochemical changes that are the initial responses of virtually all organisms to environmental stimuli. 
Most species are sensitive to relatively few toxicants and their sensitivities vary as conditions change. Therefore, each test method has particular uses and limitations and no single test has universal

applicability. One of the most informative approaches for toxicity testing is to combine biochemical tests with other test methods in a "battery of tests" that is diversified enough to characterize different types of toxicants and different trophic levels. However, such an approach can become costly, and if not carefully designed, it may not yield enough additional information to warrant the additional cost.

The application of toxicity tests to large-scale water-quality assessments is hampered by a number of difficulties. Toxicity tests often are not sensitive enough to enable the user to detect most contaminant problems in the natural environment. Furthermore, because sensitivities among different species and test conditions can be highly variable, conclusions about the toxicant problems of an ecosystem are strongly dependent on the test procedure used. In addition, the experimental systems used in toxicity tests cannot replicate the complexity or variability of natural conditions, and positive test results cannot identify the source or nature of a problem without accompanying chemical analyses. Finally, it is difficult to develop adequate control systems for toxicity tests that use ambient waters or sediments as exposure media. 


\title{
INTRODUCTION
}

\author{
Need for Biological Methods in Water-Quality Assessment
}

Protection and enhancement of water quality ultimately depends on establishment of sound management policy on regional or national levels. The development of management policy is, in turn, dependent on regional or national programs to assess water quality--its current conditions, trends, and controlling factors. One of the particularly important and challenging needs in developing such large-scale assessment programs is appropriate planning of the collection and analysis of biological data.

There can be little doubt as to the need for biological information to accurately evaluate water-quality conditions. The terms "pollution" and "contamination" generally refer to environmental occurrence of foreign substances that are biologically detrimental. Therefore, much of the concern for water-quality degradation is biologically motivated.

The importance of biological analyses is further underscored by our understanding that water quality is not simply an expression of chemical characteristics. It is strongly influenced by biological activity, and conversely, it strongly influences the composition and function of the biological community. For example, nitrogen and phosphorus concentrations in natural water systems are affected by uptake in algal cells (Richey, 1979; Goldman and Horne, 1983, p. 126; Schindler, 1985), and algal photosynthesis and biomass are conversely dependent on inputs of nitrogen and phosphorus (Smith, 1982; Canfield and others, 1985). The information from biological measurements often can be used to complement information from physical and chemical measurements, leading to better descriptions of water-quality conditions and improved understanding of the processes causing the conditions.

A variety of biological assessment procedures can contribute to understanding of the complex relations among biological, physical, and chemical characterisitics of an ecosystem. Among the most commonly used procedures to characterize the biological aspects of water quality are measurements of :

1. the distribution and abundance of floral and faunal species within an ecosystem (community surveys),

2. biological processes, such as respiration and primary productivity,

that are common indicators of community metabolic activity,

3. biological products, such as chlorophyll and ATP (adenosine

triphosphate), that also are common indicators of metabolic activity,

4. biogeochemical processes that influence the chemical character of water and sediments,

5. occurrence of pathogenic organisms,

6. biological uptake and depuration of contaminants that occur in the aquatic habitat, and

7 . effects of water pollution on biota. 
The results of one or more of these types of biological analyses, combined with chemical and hydrologic data, may be used to: (1) define and quantify biological processes that affect physical and chemical aspects of water quality; (2) determine the sanitary quality of the water; (3) determine the occurrence, distribution and fate of contaminants; and (4) assess the relation between the physical and chemical factors and the functional or structural aspects of the biological community.

\section{Difficulties of Biological Methods in Water-Quality Assessment}

Notwithstanding the obvious need for implementation of biological procedures in large-scale studies of water quality, it is clear that there are particular problems that are likely to be associated with biological waterquality-assessment work. The heterogeneous nature of biological systems is among the most important of such problems. Biological variables can fluctuate widely over space and time, and are influenced by innumerable physical, chemical, and ecological factors (Hutchinson, 1953; Odum, 1969; Wallen and Botek, 1984). Furthermore, species distributions are extremely patchy (nonuniform), even within a single ecosystem (Odum, 1971, p. 205), and certainly over broad geographical areas. Different species respond very differently to particular environmental stimuli or stresses (Luoma, 1977). Biological variability severely limits universal applicability of native bioindicator organisms. It becomes very difficult to separate effects of contaminants from natural variation, especially in comparisons among different aquatic systems.

Problems of methodology are important considerations in developing a biomonitoring program. Some biomonitoring methods are not well defined, tested, or verified. This is partially due to the biological variability and nonuniform species distribution already mentioned. For some types of analyses (toxicity tests, or biogeochemical process measurements, for example), it is extremely difficult to establish standardized procedures to be used in a consistent manner throughout a large-scale program. Even if a satisfactory procedure is available, the cost of applying it widely throughout a region can be prohibitive. Many types of biological analyses are labor-intensive. This is especially true for large-scale assessments because natural variability requires that large amounts of data be collected to compensate for the variability.

\section{Purpose and Scope}

This report examines toxicity testing--just one of the different types of biological measurement that might be used for evaluation of water quality. The overall purpose of the report is to evaluate the utility and feasibility of current toxicity-test methods for ambient water-quality assessments conducted on regional or national scales. Toxicity testing has been used widely in specialized research projects, but certain limitations of current procedures cast some doubt as to whether it can be successfully applied to large-scale water-quality assessment. 
Specific questions addressed in this report include the following:

1. What are the characteristics and applications of different types of toxicity tests?

2. What are the advantages and disadvantages of different types of test procedures, particularly with reference to application in large-scale waterquality assessments?

3. Do the results of toxicity tests accurately reflect environmental conditions and the probable effects of contaminants on biota in natural systems?

4. Will different toxicity tests result in different conclusions about existing toxicant problems in the environment?

5. Are there particular types of tests, with respect to specific test species, test substances (ambient or artificial), and test media(water or sediment), that are especially suitable for ambient water-quality assessment and that can be applied by using standardized procedures to a broad range of aquatic systems and environmental conditions?

The evaluation of toxicity testing for water-quality assessment is based largely on review of existing information. This information includes background data about the current status of toxicological methods and toxicity-test results from published aquatic toxicological studies. Various types of toxicity-test designs are discussed, and criteria for selection a test organisms and testing procedures are identified.

A great deal of information about procedures and applications of aquatic toxicity tests has been published in reports and technical papers in scientific literature (Kline and others, 1987). It is not the purpose of this review to provide an exhaustive coverage of this literature. Instead, the objective is to summarize important concepts and conclusions that are contained in many past and current reports on toxicity-test applications and to consider the implications of these concepts for possible application of the methodology in large-scale projects.

Detailed descriptions of methods also may be found in the literature. Appendix 1 identifies some of these sources and includes a discussion of general methodological principles.

The term "toxicity test" as discussed in this report refers to any waterquality-assessment procedure that involves monitoring of responses of organisms to environmental stresses after exposure of the organisms to such stresses either in the natural environment or in controlled enclosures. The effects of the stresses are evaluated by monitoring an "endpoint" response. The endpoint may be mortality, or it may be a sublethal response. Toxicity tests have been used frequently in a wide variety of studies of pollutant impacts on aquatic systems. 
An "ambient" toxicity test is one in which the stress on the test organism is produced by exposure to a natural water or sediment sample, or an extract of such a sample. This differs from a more controlled experimental situation in which the test organisms are exposed to known concentrations of specific toxic agents. Ambient testing would be the method of choice if the results are to be used for assessment of existing water or sediment quality.

The term "bioassay" is commonly used interchangeably with "toxicity test" in aquatic toxicological studies. Technically, the terms are not synonymous (Murty, 1986, p. 117). A toxicity test is used to determine the toxicity of an agent to a test species. A bioassay test, like a chemical test, is used to measure the concentration of a chemical or effluent, using biological response intensity as a means of quantification. By these definitions, the "toxicity test" more closely signifies the procedure that is appropriate for waterquality assessment where ambient materials are examined for possible content of toxic agents. Hence, "toxicity test" is the preferred term throughout the remainder of this report.

\section{Acknowledgments}

Consultation with many researchers contributed substantially to the background information used for the preparation of this report. Consultants included Peter Chapman of EVS Consultants, Vancouver, B.C., Canada; John Lawrence and Bernard Dutka of the Canadian National Water Research Institute; Teresa Norberg-King and Alan Nebeker of the U.S. Environmental Protection Agency; John Cairns of the Virginia Polytechnic Institute and State University; and Harry Leland of the U.S. Geological Survey.

\section{BENEFITS AND LIMITATIONS OF TOXICITY TESTING}

\section{Benefits}

Toxicity tests show directly how certain organisms respond to contaminants under certain conditions. They supply complementary data that can help fill some of the information gaps left by chemical analyses.

There are some very compelling arguments for the use of toxicity tests in assessment of water quality. Regardless of what levels of contaminants are found in the environment, their effects on biota are unknown without some biological measurements. Furthermore, chemical analyses, no matter how extensive, cannot include measurement of all possible toxic agents that may occur in the system. Not only do toxicity tests show biological effects of specific contaminants, they also integrate the effects of combinations of contaminants including those that are not detected by the established analytical methods.

In most cases of environmental contamination, more than one toxic substance is present at concentrations greater than background levels. The effects of combinations of toxic substances are likely to be different than 
the sum of their individual effects (Voyer and Heltshe, 1984). In cases of synergism, the total effect is greater than individual toxicities would suggest (Macek, 1975; Thompson and others, 1980; Hermens and others, 1984a). Conversely, where antagonism occurs, the total effect is smaller than might be caused by the substances' individual effects (Bartlett and others, 1974; Christensen and others, 1979; Hemelraad and others, 1987). Sequential exposure to two or more toxicants may sensitize biota so that they are more susceptible to damage after the initial exposure (Trevors and others, 1982). Mere detection of the toxicants reveals nothing of these kinds of interactions.

Occurrences of environmental contaminants are further complicated by nonuniform spatial or temporal distribution. Intermittent releases into the environment may occur, especially from point sources that discharge directly to the affected ecosystem (Elder and Dresler, 1988). Water concentrations of pollutants are especially subject to temporal variability because the water is mobile and contaminant inputs tend to be quickly transported or diluted. Sediments, as historical integrators of water quality (Feltz, 1980), tend to accumulate substances from the overlying water, and are much less prone to show short-term temporal fluctuations in contaminant concentrations. However, sediments are likely to show considerable spatial variability of contaminant concentrations (Salomons and Forstner, 1984, p. 165). Chemical detection of contaminants is thus highly dependent on sampling time and frequency (in the case of water and suspended sediments) and sampling location (in the case of sediments). Certain toxicity tests, primarily those that are conducted in situ, may diminish this problem by integrating effects over time and space.

Another reason for use of toxicity testing in water-quality assessment is the limited capability of chemical analysis to detect specific forms and degradation products of metals and organic compounds. Total toxicant concentration data can be misleading because the toxic effects can vary enormously depending on the speciation of the chemical (Diks and Allen, 1983; Mayes and others, 1985). Furthermore, chemical analyses may not show the products of degradation that are likely to have different toxicological effects than those of the parent compounds (Mayes and others, 1985).

\section{Limitations}

There also are limitations to the use of toxicity tests. Principal among these is that it is extremely difficult, if not impossible, for toxicity-test models to truly mimic natural systems. Therefore, responses of selected test organisms to contaminants in a controlled environment are unlikely to accurately represent the responses of a complex natural community to the same contaminant. Furthermore, it is unlikely that the biota in the natural system would be presented with the same simplicity of exposure that is characteristic of the regulated and relatively constant conditions of a toxicity test.

Because of this weakness, toxicity tests have questionable predictive value, and may even be misleading. 
Another limitation of toxicity testing is the difficulty of identifying cause-effect relations. Even if a test demonstrates toxicological responses of biota exposed to ambient water or sediments, it cannot identify the substances or their concentrations that cause such responses. Chemical analyses are needed to identify possible toxic agents that are present in the system. The coupling of biological and chemical monitoring procedures to obtain complementary data has been effective in some studies (Pessah and Cornwall, 1980; Long and Chapman, 1985). However, the identification of contaminant occurrence at elevated concentrations and simultaneous observation of abnormal responses of biota in bioassay tests does not necessarily demonstrate cause-effect relations.

Most toxicity tests are conducted in enclosures outside of the natural aquatic environment. Many of the physical and chemical conditions within the test enclosures are controlled. Factors such as temperature, salinity, water hardness, $\mathrm{pH}$, and photoperiod may vary from study to study. Sometimes they are set to be consistent with conventional experimental methods. In other cases they may be set to mimic, as closely as possible, the natural environmental conditions of the test species. Control of the test conditions is needed in order to interpret the results. However, the ambient conditions are likely to have a significant effect on test results (Leeuwangh, 1978; Judy and Davies, 1979; Graney and others, 1984; Babich and Stotzky, 1985). Variability of uncontrolled test factors, such as bacterial activity, chemical speciation, and health of the test organisms, may increase further the variability of test results.

Another cause of response variability is the wide variance of different species in their sensitivities and responses to any particular toxic substance (Plotkin and Ram, 1984; Phipps and Holcombe, 1985; Slooff, 1985). Even within a single species, there may be significant differences in sensitivities among individuals of different sexes, age groups, and genotypes (Adelman and Smith, 1976; Wright and Frain, 1981; Woltering, 1984; Nebeker, Cairns and Wise, 1984; Nebeker and others, 1985). Such biological nonuniformity, compounded with the variability due to test conditions, usually invalidates attempts to make comparisons among different studies.

Toxicity-test methodology generally calls for relatively standard formats for evaluating biological responses. In particular, the standard endpoints are concentrations that, in a specified time period, produce mortality in half the tested population ("50-percent lethal concentration" or LC50) or elicit an observable response in half the tested population ("50-percent effective concentration" or EC50). White and Champ (1984) criticized these endpoints, stating that they are arbitrarily chosen for the convenience of reporting results and have no demonstrated relevance to true hazard levels in the natural environment. Because of the dependence on test conditions, the 50percent effective dose level may vary over several orders of magnitude. Hence, the toxicity-test results may have limited broad-scale significance for human health or environmental preservation. However, despite the implications of their title--"The great bioassay hoax, and alternatives"--White and Champ (1984) did not demonstrate total uselessness of toxicity-test methods or applications. The authors did not deny that use of biological indicators can be a valuable tool to complement other kinds of data in an evaluation of 
environmental contamination. In fact, they suggested that toxicity studies can be designed and implemented so that they are useful, provided they meet the critical criteria of scientific soundness, adequate relation to natural systems, and relation to broad-scale processes.

Practical and logistical difficulties of toxicity testing can be considerable. Most tests require an elaborate laboratory setup and specially trained personnel. Test organisms are often reared in captivity, which may itself introduce variables that can affect experimental results (Ten Berge, 1978; Goulden and others, 1982). Applications of toxicity-test procedures over a broad geographical area to assess regional or national water-quality problems require either the operation of numerous laboratories in different areas or transport of samples to a central processing laboratory. Either option poses logistical problems.

One of the major difficulties with ambient tests is the establishment of control systems. It was pointed out by Wong (1984) that "a control medium can never be obtained since we can neither remove contaminants from ambient waters nor can we simulate water with identical chemistry." Even if simulation could be achieved, the conditions in ambient media are not static, and it would be impossible to simulate natural fluctuations. The usual solution to this problem is to avoid control systems altogether and depend either on serial dilutions of the ambient media (De Vries and Hotting, 1985; Gaur and Kumar, 1986) or comparisons among samples from different sites (Long and Chapman, 1985; Mount and Norberg-King, 1985; Norberg-King and Mount, 1986) to evaluate relative toxicity.

The limited capacity of toxicity testing to predict ecological effects of toxic agents within a complex and variable aquatic ecosystem was emphasized by Stumm and others (1983). The authors stressed a need for consideration of various processes, such as adsorption, atmospheric exchange, microbial degradation, and chemical transformation, that affect the chemistry and biological availability of toxicants. It was suggested that toxicity testing, even if combined with chemical monitoring, is not enough; meaningful information about environmental cycling of contaminants depends on modeling based on data that describe compound-specific variables (including solubility, vapor pressure, and lipophility), transformation processes, and spatial and temporal distribution of contaminants in the natural environment.

Special Considerations for Large-Scale Toxicity Testing

Toxicity testing on a regional or national scale would have special requirements distinct from those of tests conducted as part of small-scale, specialized studies. The most important consideration is that tests would be applied to a wide diversity of sample sites. Many different contaminants would be encountered; hence, tests would not be aimed at particular toxic compounds or elements. Environmental variables and biological communities would also vary over broad ranges among different sites. There would be little value in designing a test that is representative of a particular community type because it would then fail for other community types. Singlespecies tests would have limited capacity to represent the diverse communities characteristic of the sample sites. 
The most important function of toxicity tests in a large-scale program would be to identify areas where indications of toxicity coincide with contaminant problems suggested by results of analyses and any other biological monitoring that may be done at the sites. The tests could serve as initial feedback mechanisms, in which the results of tests at any given site may determine whether or not more detailed monitoring or research at the site is advisable.

In addition to being diverse, most of the sample sites would be free of severe contamination. To assess the quality of usable waters, the emphasis would be on natural waters rather than on effluents, leachates, or other directly contaminated materials. For a toxicity test to be useful on natural water and sediment samples, it must be sensitive to relatively low concentrations of at least some contaminants. At the same time, the test should not be so complex, time-consuming, or expensive that it could not be conducted on a large number of samples from widely dispersed locations.

The broad geographical distribution of study sites in a large-scale project would almost certainly require shipment of samples to a central laboratory for analysis. There would be a need to test for possible changes in toxicity characteristics of the samples during shipment.

\section{USES OF TOXICITY-TEST RESULTS}

Some possible uses of toxicity tests are shown in table 1 . They are listed in order of the probable risk of error, although the absolute risk may vary considerably among different situations, owing to different kinds of restrictions presented by different cases. It is impossible to entirely eliminate the risk of error. Hence, there is always a dilemna in designing or interpreting a test. If the test is overextended (more is interpreted from the test results than the data can support), the amount of information produced may be impressive, but there is a substantial risk that much of it is erroneous. If the test is underextended, the risk of error is low, but the amount of information generated may be so minor that the test was hardly worth the effort.

Toxicity-test results provide information on the toxicity of particular contaminants to particular organisms under particular conditions. This can be valuable information if used in the proper context. However, extrapolation of the results to more general conditions may lead to erroneous or misleading interpretations. A few studies have demonstrated some of the difficulties of extrapolation of toxicity-test results to predict toxicant effects in situations other than the specific tested case. Nevertheless, a certain amount of extrapolation may be valid. Chapman (1983) emphasized that existing laboratory toxicity-test data are generally inapplicable as precise indicators of toxic-effect levels in nature, although they have considerable capability for answering site-specific questions. Interspecific variation in sensitivity 
to toxicants should discourage most attempts to extrapolate results to nontested species. Nevertheless, LeBlanc (1984) pointed out that closely related species have similar sensitivities to most chemicals. It is reasonably safe to assume, for example, that a substance that produces a toxic response in bluegills will also have some toxic effect on large-mouth bass, but it would probably be invalid to assume similar toxicity to invertebrate species based solely on the bluegill results. As the breadth of extrapolation increases, so does the risk.

Uses of toxicity-test results are determined in part by recognition of limitations of the tests balanced against the needs and possible benefits of the tests. Because of the limitations, some water-quality researchers may be discouraged from including any kind of toxicity-testing procedures in their investigations. On the other hand, if toxicity-testing procedures are to be included, full awareness of their limitations will enable the researchers to minimize the detrimental effects of these limitations.

Table 1.-- Some possible uses of toxicity tests, in order of the probable risk of error

Risk factor.

Low

1. Identification of toxic conditions in waters or sediments without describing effects of those conditions

2. Verification of other assessment measurements

3. Assessment of effects of toxic conditions on one or a few test species

4. Prediction of effects of toxic conditions on one or a few test species

5. Assessment of effects of toxic conditions on entire communities

6. Prediction of effects of toxic conditions on entire communities

7. Establishment of environmental standards 
Some of the important potential problems of toxicity testing can be avoided or diminished by initiating the study with a clear perception and statement of its purpose. The stated purpose should be adequately restrictive with respect to the possible applications of the test results shown in table 1 so that the test is not overextended. In addition, the purpose should be suited to the needs and constraints of the investigation and the study area. An appropriate statement of purpose, followed by execution of the study such that it fulfills the purpose, will do a great deal to minimize misinterpretation and perceptions that the test results are irrelevant or unimportant.

\section{PROCEDURES AND APPLICATIONS}

A wide variety of toxicity-test methods have been developed to fulfill the needs of diverse applications. Each test has particular purposes and limitations, and no test is universally applicable. The test methods may be distinguished primarily on the basis of four characteristics: (1) test species, (2) endpoints (acute or chronic, and variations of each), (3) test enclosure, and (4) test substance (toxicant) which acts as the environmental stress. Some aspects of each of these design characteristics are discussed here.

\section{Test-Species Selection}

The most important feature that distinguishes different toxicity-test methods is the selection of plant or animal species to be used as indicators of contaminant effects. This is a necessary early step in nearly all toxicity-test procedures. Because of the difficulty of testing toxicity responses of all potentially affected organisms in the natural water body of interest, one or a small number of bioindicator species are generally used to represent a larger community.

The selection of test species is usually based on several criteria related to the reliability of the organisms as indicators and the feasibility of their use as captive organisms. Various authors have discussed important requirements for a species to be useful as a toxicity-test organism (Phillips, 1980; Benfield and Buikema, 1980; Nebeker and others, 1984). Some requirements, or criteria for species selection, are shown in table 2, listed in order of estimated importance. Any species that does not meet the description given for a particular criterion is less than ideal as a test species with respect to that criterion.

Among the great variety of aquatic floral and faunal species, a relatively small number have emerged as favorites in toxicological research. Most species simply do not meet enough of the requirements listed in table 2 to be considered as test organisms. Even among those that are acceptable, none of them would be considered exceptional with respect to all 12 criteria. Each species has particular characteristics that limit its use in certain applications and no species clearly stands out as a "universal" indicator. 
Although the criteria are listed in table 2 in order of estimated overall importance, the priorities of specific studies may alter this order considerably. Hence, species selection depends to a large extent on the peculiarities and objectives of the study.

Most of the species commonly used in freshwater toxicity tests discussed later in this report are listed in tables 3 and 4 . Their taxonomic lineages are shown in figure 1. A wide variety of taxonomic groups and trophic levels are represented. This variety of usable species enhances the potential usefulness of toxicity testing for characterizing aquatic communities; selection of a few test species may provide information about toxicant effects for a broad spectrum of organisms in the community. However, because of pragmatic and economic considerations, the scope of most studies is limited to one or two test species.

Certain characteristics of taxonomic groups and individual species including habitat, trophic level, economic importance, and tolerance ranges for environmental variables influence the selection of toxicity-test species. Information about these characteristics is given in tables 3 and 4 . More detailed information can be found in the reference publications listed at the end of table 4 .

Species selections are made by toxicity-test researchers for various reasons. The reasons are not given in most published reports, especially if the species is well known as a test organism. If there is an established precedent of its use for toxicity testing, then there is generally an implied assumption that its use is appropriate for the particular study being reported. However, many investigators do give explicit reasons for their test species choices. Tables 5-10 compile some of the published statements for particular species selections in a variety of toxicity-test studies.

The information shown in tables 5-10 was originally assembled to indicate patterns of strengths and weaknesses of different species. For each species, it was expected that authors would observe similar advantages and disadvantages with respect to a particular set of criteria. In other words, species were expected to be distinguishable in their patterns of strengths and weaknesses. In fact, the tables show little consistency in how species were rated on a particular criterion. There was considerable overlap in stated advantages and disadvantages of species or related groups of species. For example, the amenability to laboratory culture (criterion \#4) was considered an advantage of Daphnia magna by several authors (table 7). An almost equal number of authors, however, stated that this species was quite difficult to culture. Pimephales promelas (table 9) was often selected because of sensitivity, as expected, but a number of other reasons were given, and no clear pattern emerged about which of those might be most important. Criterion \#6 (relevance) might be expected to be an important reason for selecting any fish species, but tables 9 and 10 do not give a strong suggestion that this criterion was more critical than many other possible reasons for selection. 
Table 2.--List of criteria for species selection in order of estimated overall importance

1. Sensitivity: the organism should respond to a variety of contaminants, at concentrations that may be encountered in the natural environment and with an intensity of responses that is related to contaminant concentration(s).

2. Representativeness: the organism should respond to the contaminant in ways that characterize responses that could be expected from a large number of other species. It should not be prone to giving false positive or false negative results.

3. Response detection: Responses or endpoints should be readily detectable and quantifiable. If life-cycle tests are used, life stages should be easy to identify.

4. Amenability to laboratory culture: the organism should be adaptable to laboratory captivity without presenting unusual problems for rearing or experimentation. Control mortality should not be a problem.

5. Reproducibility of results: Repeated experiments should give uniform results, within acceptable error limits. There should not be a great deal of variability among individuals in their responses to contaminants.

6. Relevance: the organism should have ecological or economic significance because of its abundance, importance in the food web, or commercial importance.

7. Simplicity of test: Toxicity-testing procedures should be simple and rapid.

8. Short-duration life cycle: If life cycle testing is to be done, the cycle should be short so that tests may be completed in reasonable time.

9. Availability of background information: A data base of toxicity information, based on results from previous work, should be available.

10. Documented methodology: There should be established and tested procedures for use of the species in toxicity tests.

11. Biological uptake activity: The contaminant cannot directly affect the organism if it is not incorporated by the organism in some way, either internally or externally. Therefore, bioaccumulation or uptake rates should be relatively rapid.

12. Low cost: Toxicity-testing procedures with the species should not be so expensive as to preclude accomplishing a meaningful number of analyses. 

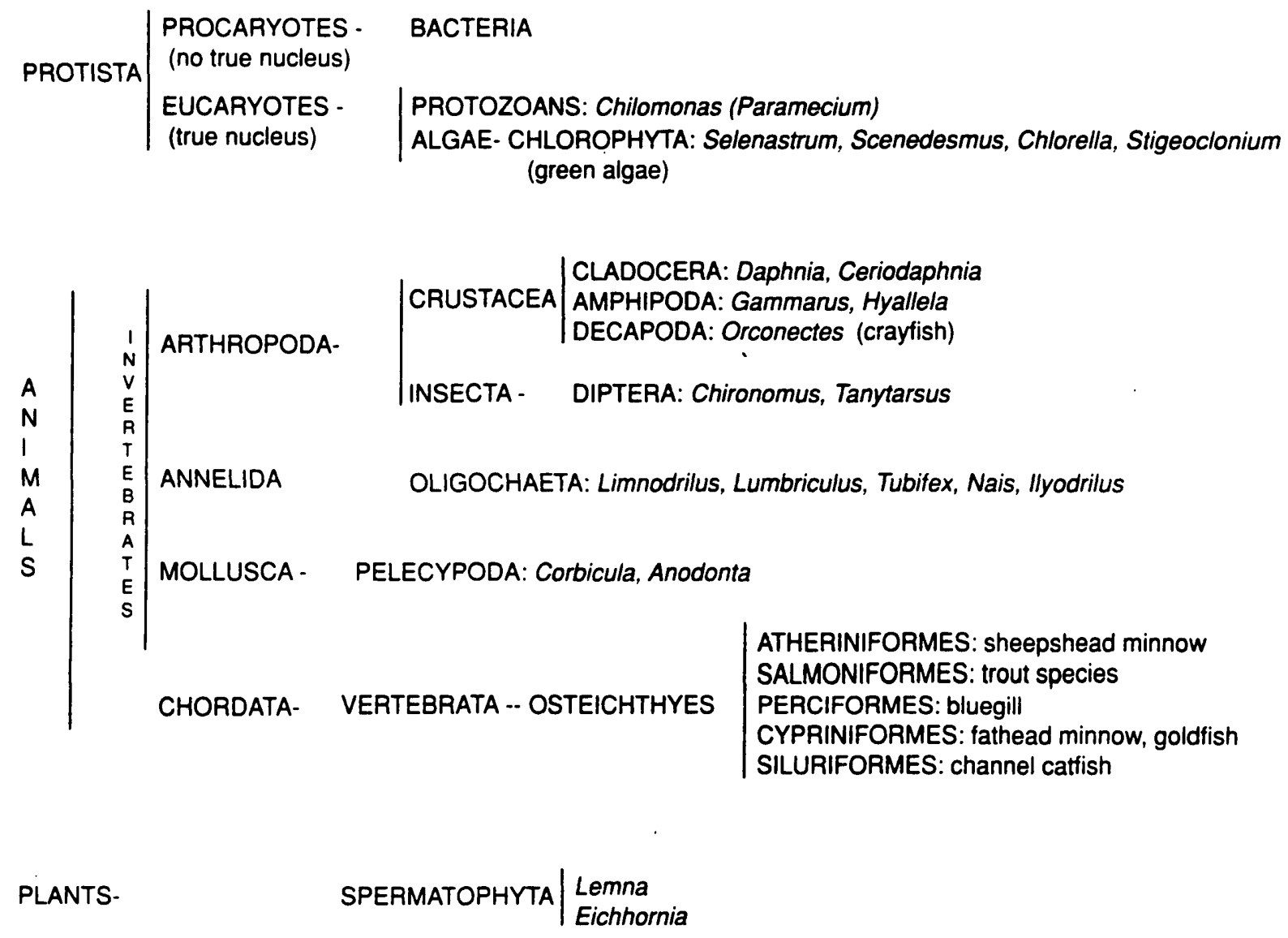

Figure 1. Taxonomic lineages of commonly used freshwater toxicity-test species. 
Table 3.--Identification and characterization of some floral and

faunal species frequently used in aquatic toxicity testing procedures

[Except for fish, common names are very general or nonexistent. ("spp." indicates various or unnamed species of this genus are used). Characteristics of adult forms, based on best information available, are indicated by "o" marker. Absence of mark signifies that characteristic does not apply or that information is not available. "L" symbol signifies larval or immature forms only. D.0. = dissolved oxygen, temp = temperature.]

\begin{tabular}{|c|c|c|c|c|c|c|c|c|c|c|c|c|}
\hline \multirow[b]{2}{*}{$\begin{array}{l}\text { Taxonomic } \\
\text { group }\end{array}$} & \multirow[b]{2}{*}{ Scientific name } & \multirow[b]{2}{*}{ Common name } & \multicolumn{4}{|c|}{ Wide tolerance range ${ }^{1}$} & \multicolumn{6}{|c|}{ Predominant trophic level } \\
\hline & & & $\mathrm{pH}$ & Temp. & D. 0 . & $\begin{array}{l}\text { Salin- } \\
\text { ity }\end{array}$ & $\begin{array}{l}\text { Decom- } \\
\text { poser }\end{array}$ & $\begin{array}{l}\text { Auto- } \\
\text { troph }\end{array}$ & $\begin{array}{l}\text { Hetero- } \\
\text { troph }\end{array}$ & $\begin{array}{l}\text { Herbi- } \\
\text { vore }\end{array}$ & $\begin{array}{l}\text { Carni- } \\
\text { vore }\end{array}$ & $\begin{array}{l}\text { Omni- } \\
\text { vore }\end{array}$ \\
\hline \multirow[t]{4}{*}{ Bacteria } & Photobacterium phosphoreum & & & o & & & 0 & & & & & \\
\hline & Spirillum voluntans & & & o & & & 0 & & & & & \\
\hline & Pseudomonas spp. & & & $\circ$ & & & 0 & & & & & \\
\hline & Aeromonas hydrophila & & & ० & & & ○ & & & & & \\
\hline Protozoans & Chilomonas paramecium & paramecium & o & o & & & & & o & & & \\
\hline \multirow[t]{4}{*}{ Green Algae } & Selenastrum capricornutum & & & 0 & & & & o & & & & \\
\hline & Scenedesmus quadricauda & & & 0 & & & & 0 & & & & \\
\hline & Chlorella stigmatophora & & & 0 & & & & 0 & & & & \\
\hline & Stigeoclonium tenue & & & 0 & & & & 0 & & & & \\
\hline \multirow[t]{2}{*}{ Macrophytes } & Lemana spp. & duckweed & & & & & & o & & & & \\
\hline & Eichhornia crassipes & water hyacinth & & & & & & 0 & & & & \\
\hline \multirow[t]{2}{*}{ Nematodes } & Panagrellus redivivus & & & & & & & & o & & & \\
\hline & Panagrellus silusiae & & & & & & & & $\circ$ & & & \\
\hline \multirow[t]{5}{*}{ oligochaetes } & Limmodrilus hoffmeisteri & & $\circ$ & o & & 0 & & & $\circ$ & & & \\
\hline & Tubifex tubifex & sludge worm & 0 & 0 & 0 & 0 & & & 0 & & & \\
\hline & Lumbriculus variegatus & & & & & & & & $\circ$ & & & \\
\hline & Nais spp. & & 0 & & & & & & 0 & & & \\
\hline & Ilyodrilus spp. & & 0 & & & 0 & & & 0 & & & \\
\hline \multirow[t]{5}{*}{ Cladocerans } & Daphnia maqna & water flea & o & o & & & & & & 0 & & \\
\hline & Daphnia pulex & " & 0 & 0 & & & & & & 0 & & \\
\hline & Daphnia pulicaria & $"$ & 0 & 0 & & & & & & 0 & & \\
\hline & Daphnia laevis & $"$ & 0 & o & & & & & & 0 & & \\
\hline & Ceriodaphnia reticulata & $"$ & 0 & 0 & & & & & & o & & \\
\hline \multirow[t]{3}{*}{ Amphipods } & Gammarus lacustris & scud & & & & & & & & & & 0 \\
\hline & Gammarus pulex & $"$ & & & & & & & & & & $\circ$ \\
\hline & Hyallela azteca & $"$ & & & & & & & & & & 0 \\
\hline
\end{tabular}


Table 3.--Identification and characterization of some floral and

faunal species frequently used in aquatic toxicity testing procedures--Continued

[Except for fish, common names are very general or nonexistent. ("spp." indicates various or unnamed species of this genus are used). Characteristics of adult forms, based on best information available, are indicated by "o" marker. Absence of mark signifies that characteristic does not apply or that information is not available. "L" symbol signifies larval or immature forms only. D.0. = dissolved oxygen, temp = temperature.]

\begin{tabular}{|c|c|c|c|c|c|c|c|c|c|}
\hline \multirow[b]{2}{*}{$\begin{array}{l}\text { Taxonomic } \\
\text { group }\end{array}$} & \multirow[b]{2}{*}{ Scientific name } & \multirow[b]{2}{*}{ Common name } & \multicolumn{2}{|c|}{ Wide ${ }^{1}$ tolerance range } & \multicolumn{5}{|c|}{ Predominant trophic level } \\
\hline & & & Tenp. & $\begin{array}{ll} & \text { Salin- } \\
\text { D.0. } & \text { ity }\end{array}$ & $\begin{array}{l}\text { Decon- } \\
\text { poser }\end{array}$ & $\begin{array}{l}\text { Auto- Hetero- } \\
\text { troph troph }\end{array}$ & $\begin{array}{l}\text { Herbi- } \\
\text { vore }\end{array}$ & $\begin{array}{l}\text { Carni- } \\
\text { vore }\end{array}$ & $\begin{array}{l}\text { Ormi- } \\
\text { vore }\end{array}$ \\
\hline Decapods & Orconectes immunis & crapfish & & & & & & & 0 \\
\hline \multirow[t]{3}{*}{ Insects } & Chironomus tentans & midge & 0 & 0 & & & $\circ$ & & \\
\hline & Tanytarsus spp. & tanytarsus & 0 & o & & & 0 & & \\
\hline & Hexagenia limbata & mayfly & 0 & & & & & & $\circ$ \\
\hline \multirow[t]{4}{*}{ Molluscs } & Corbicula manilensis & Asiatic clam & & & & & & & o \\
\hline & Corbicula fluminea & Asiatic clam & & & & & & & $\circ$ \\
\hline & Musculium transversum & fingernail clam & & & & & & & 0 \\
\hline & Anodonta cyqnea & & & & & & & & 0 \\
\hline \multirow[t]{9}{*}{ Fish } & Pimephales promelas & fathead minnow & & & & & & & 0 \\
\hline & Salmo gairdneri & rainbow trout & & & & & & o & \\
\hline & Salmo trutta & brown trout & & & & & & o & \\
\hline & Salmo clarki & cutthroat trout & & & & & & 0 & \\
\hline & Salvelinus fontinalis & brook trout & & & & & & 0 & \\
\hline & Lepomis macrochirus & bluegill & & & & & & & 0 \\
\hline & Carassius auratus & goldfish & & & & & & & 0 \\
\hline & Ictalurus punctatus & channel catfish & & & & & & & 0 \\
\hline & Cyprinodon variegatus & sheepshead minnow & & & & & & & 0 \\
\hline
\end{tabular}


Table 3.--Identification and characterization of some floral and

faunal species frequently used in aquatic toxicity testing procedures--Continued

[Except for fish, common names are very general or nonexistent. ("spp." indicates various or unnamed species of this genus are used). Characteristics of adult forms, based on best information available, are indicated by "o" marker. Absence of mark signifies that characteristic does not apply or that information is not available. "L" sYmbol signifies larval or immature forms only. D.0. = dissolved oxygen, temp = temperature.]

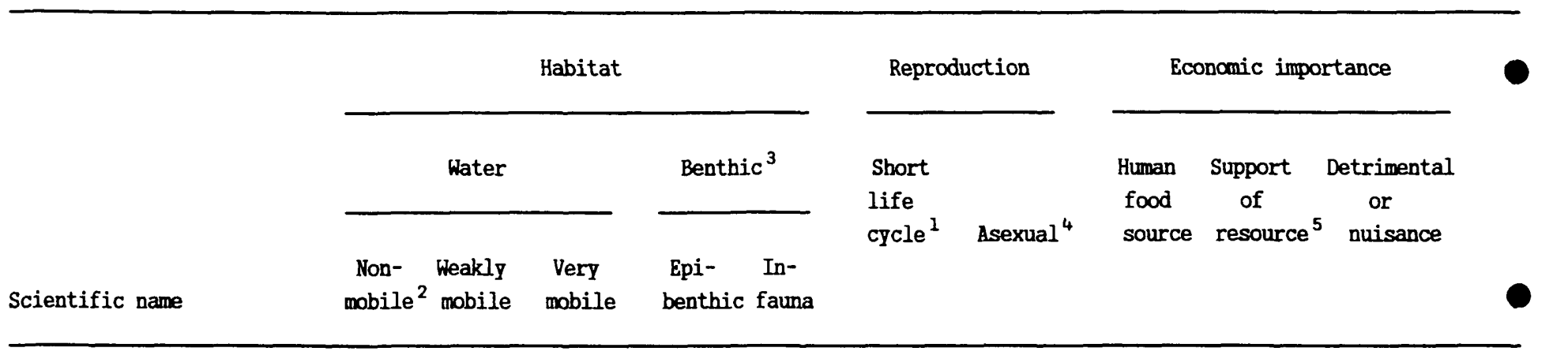

Spirillum voluntans

Pseudomonas spp.

Aeromonas hydrophila

o

o

Chilomonas paramecium

Chilomonas paramecium

Selenastrum capricornutum o

Scenedesmus quadricauda 0

Chlorella stiqmatophora o

Stigeoclonium tenue

Lerma spp.

Eichhornia crassipes

Panagrellus redivivus

Panagrellus silusiae

Limodrilus hoffmeisteri

Tubifex tubifex

Lumbriculus variegatus

Nais spp.

Ilpodrilus spp.

Daphnia magna

Daphnia pulex

Daphnia pulicaria

Daphnia laevis

Ceriodaphnia retic
0

0

0

0

0

0

0

o 
Table 4.--General characteristics of flora and fauna used in toxicity tests

Taxonomic

group Special characteristics pertinent to use as test species

BACTERIA

PROTOZOANS

ALGAE

MACROPHYTES

NEMATODES

OLIGOCHAETES

AMPHIPODS

DECAPODS

(Crayfish)
Microscopic, unicellular, anatomically simple (no true nucleus or nuclear membrane; no mitotic division). Biochemistry of luminescence or other endpoints is similar to cytochrame-linked respiratory chain common to other organisms. Luminescence requires much energy; hence it is likely to be responsive to toxicants.

Unicellular, but cellular organization is complete, like in multicellular organisms. Cilia or flagella provide mobility, but small size makes protozoans subject to transport by currents or wave action. Chilomonas paramecium, most common test species, injests no particulate food; utilizes dissolved organic matter to synthesize protoplasmic substance.

Commonly used as indicators of water quality (Rawson, 1956; Palmer, 1969). Important ecological niche as primary producers at base of food web. Utilize dissolved substances, thus not affected by toxicants in sediments, except to extent that such pollutants are desorbed into water. Most frequently used test species is single-celled green algae (Chlorophyta). Selenastrum capricornutum, easy to culture, identif $\bar{Y}$, and quantify, is among most comonly-used of all test species.

Larger plants, rooted or free-floating. Lemna and Eichbornia are both free-floating, often in dense populations; can be nuisances by clogging waterways or causing oxygen depletions upon decay. Can also be beneficial as food and shelter for other organisms, and for contributions to photosynthesis and element cycling. Limited toxicological data available (Bowmer, 1986).

Extremely abundant and widely distributed in all kinds of aquatic systems. Not widely used as test species; poor sensitivity to most toxic agents.

Aquatic counterparts to terrestrial earthworms. Many test species have been used, but none widely used. Relative to arthropods, tend to be more tolerant of pesticides, but less tolerant of toxic metals (Brinkhurst and Cook, 1974). Tubifex tubifex tolerant of unfavorable environmental conditions; hence usually considered a pollution indicator.

Extremely common in freshwater systems. Filter-feeders. Tend to be more sensitive to metals than to organics. Life cycle includes instars, separated by molts. Daphnia magna most commonly-used of all test species. Ceriodaphnia reticulata distinguished from other cladocerans by small size, short life cycle, and common occurence in a variety of freshwater habitats.

Gammarus species among most commonly used test organisms, especially for sediment-toxicity tests. Life cycle includes instars, separated by molts.

Widely distributed, especially in southeastern United States. Life cycle includes instar stages, separated by molts. During molts, animals are more sensitive to toxicants (Hobbs and Hall, 1974). orconectes immunis, an active burrower, inhabits sluggish streams and ponds. 
Table 4. --General characteristics of flora and fauna used in toxicity tests--Continued

TNSECTS

MOLLUSCS

FISH
Extremely adaptive to all kinds of environments. Great diversit 1 reflects environmental conditions; hence useful bioindicators. Chironomidae is one of largest families --- widely distributed and often extremel\ abundant (up to 50,000 per square meter). Difficult to identify Chironomid species.

Extreme economic importance, both beneficial and detrimental. Filter-feeding bivalves (clams and molluscs) most common test species. Corbicula larval stages are ciliated and free-swimming, unlike most other bivalve species. Corbicula can exploit nearly anp type of substrate.

As the only vertebrates commonly used in toxicity tests, fish represent higher trophic levels than other test species. Eggs or early life stages usually more sensitive to toxicants than adults. Contain high lipid concentrations [up to 15 percent of total body weight (Niimi, 1983)]; hence hydrophobic substances, primarly organics, readily accumulate in fish tissue (Chiou, 1985). Extreme mobility often allows escape from toxic sources in natural systems. Pimephales promelas used

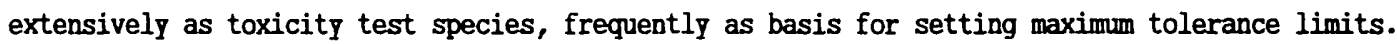

References, for more information:

Ward and Whipple, 1959 (invertebrates, macrophytes)

Meglitsch, 1967 (invertebrates)

Prescott, 1970 (algae)

Brinkhurst and Cook, 1974 (oligochaetes)

Mitchell, 1974 (bacteria)

Pennak, 1978 (invertebrates)

Brock, 1979 (bacteria)

Anderson, 1980 (chironomids)

Arthur, 1980 (amphipods)

Benfield and Buikema, 1980 (invertebrates)

Bitton, 1982 (bacteria)

Bone and Marshall, 1982 (fish)

American Public Health Association, 1985

Hobbs and Hall, 1974 (crayfish)

Fuller, 1974 (bivalves)

Roback, 1974 (insects)

Rheinheimer, 1974 (bacteria) 
Tables 5-10.--Evaluation of commonly used toxicity-test species with respect to selection criteria listed in table 1

[Data are from published studies in which indicated species were used or discussed. Ratings with respect to numbered criteria are based on statements by authors: "+" = advantage of this species over other commonly used species; "-" = disadvantage of this species; "+" = advantageous in some cases, disadvantageous in others (for example, species may be sensitive to some toxicants and insensitive to others).

Test type codes: "A" = acute; "C" = chronic; "S" sediment bioassay

Toxicant codes: "M" = metals, "I" = inorganics, excluding metals, "O" = organics, in general, "OP" = organic pesticides, "OH" = organic herbicides, "PC" = petroleum or coal tar derivatives, " $\mathrm{N}$ " = natural sediments or water; "E" = effluents, "var" = various.]

Table 5. -- Bacteria

[In all cases, contaminant effects are detected by measuring changes in luminescence or other metabolic functions]

\begin{tabular}{|c|c|c|c|c|c|c|c|c|c|c|c|c|}
\hline \multirow[b]{2}{*}{ Species } & \multirow[b]{2}{*}{ Toxicant(s) } & \multicolumn{10}{|c|}{ Criterion number (from table 2) } & \multirow[b]{2}{*}{ Reference } \\
\hline & & 1 & 2 & 3 & 4 & 5 & 6 & 7 & 8 & 91 & 01112 & \\
\hline Bacteria (var. species) & & + & & & & + & & + & & & + & Greene \& others, 1985 \\
\hline Bacteria (var. species) & var & & + & & & & & + & & & + & Berkowitz, 1979 \\
\hline Bacteria, var. species & var & + & + & & & & & + & & & & Bulich, 1979 \\
\hline Photobacterium phosphoreum & & + & & & & - & & + & & & & Dutka \& Kwan, 1981 \\
\hline Photobacterium fischeri & 0 & + & + & & & & & + & & & & Lebsack \& others, 1981 \\
\hline Photobacterium phosphoreum & 0 & + & + & & & + & & + & & & & Curtis \& others, 1982 \\
\hline Photobacterium phosphoreum & $M, 0, E$ & \pm & & & & + & & + & & & + & Qureshi \& others, 1982 \\
\hline Bacteria (var. species) & var & + & + & & + & - & & + & + & & + & Bitton, 1982 \\
\hline Photobacterium phosphoreum & $\mathrm{M}, \mathrm{O}$ & + & + & & & + & & + & & & + & DeZwart \& Sloof, 1983 \\
\hline Photobacterium phosphoreum & $M, 0$ & - & & & & - & & + & & & + & McFeters \& others, 1983 \\
\hline Photobacterium phosphoreum & 0 & + & + & & + & & & + & & & + & Ribo \& Kaiser, 1983 \\
\hline Photobacterium phosphoreum & var & + & & & & + & & + & & & & Vasseur \& others, 1984 \\
\hline Photobacterium phosphoreum & var & + & + & & & + & & + & & & + & Coleman \& Qureshi, 1985 \\
\hline Spirillum voluntans & var & + & + & & & + & & + & & & + & Coleman \& Qureshi, 1985 \\
\hline Photobacterium phosphoreum & nat & & & & + & & & & + & + & + & Schiewe \& others, 1985 \\
\hline Pseudomonas putida & $\mathbf{M}, \mathbf{O}$ & + & & + & + & & & & + & + & + & Slabbert, 1986 \\
\hline
\end{tabular}


Table 6. - - Alqae

[In all cases, contaminant effects are detected by changes

in growth, productivity, or other metabolic function]

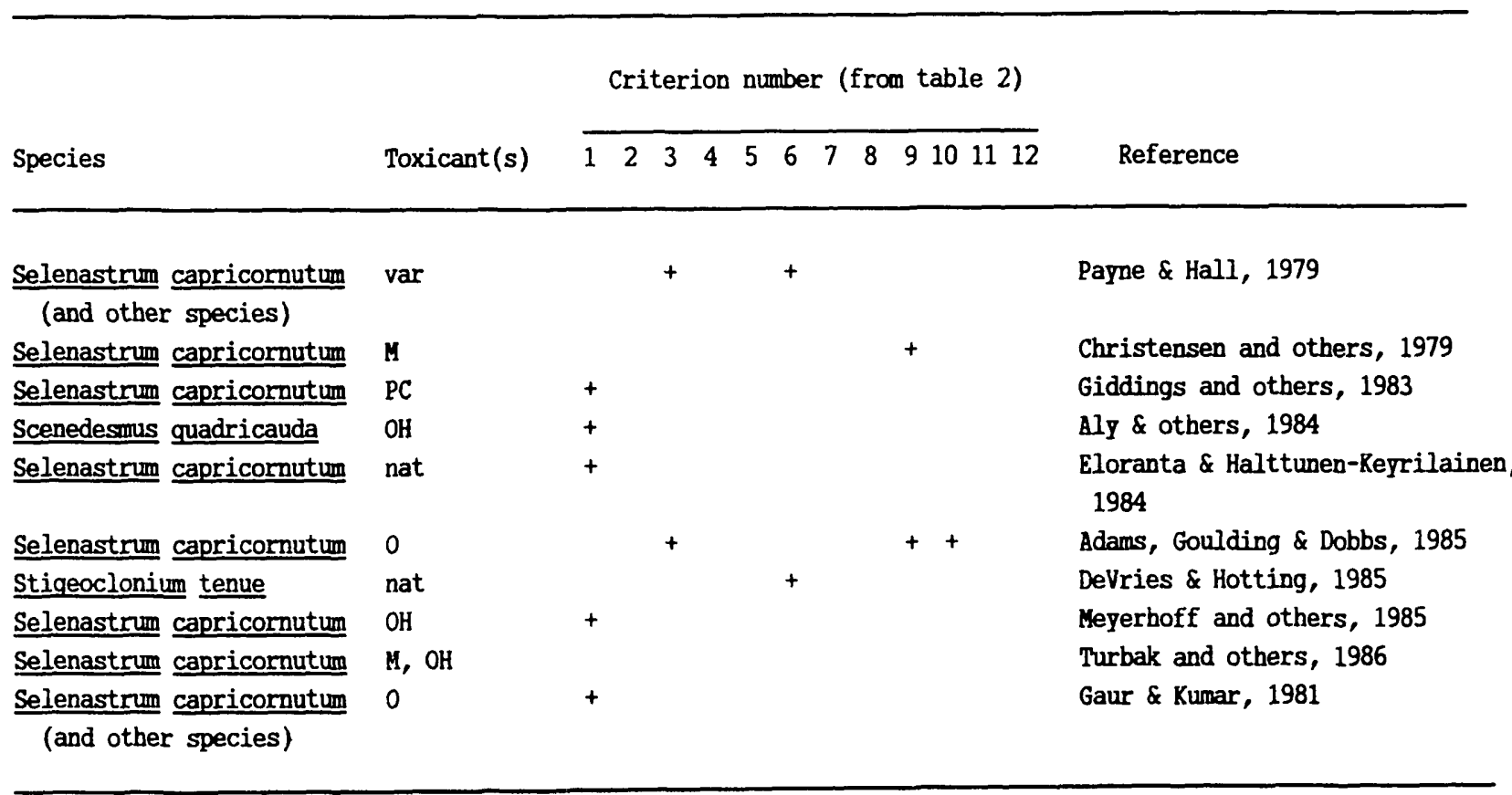

Table 7.--Daphnia magna

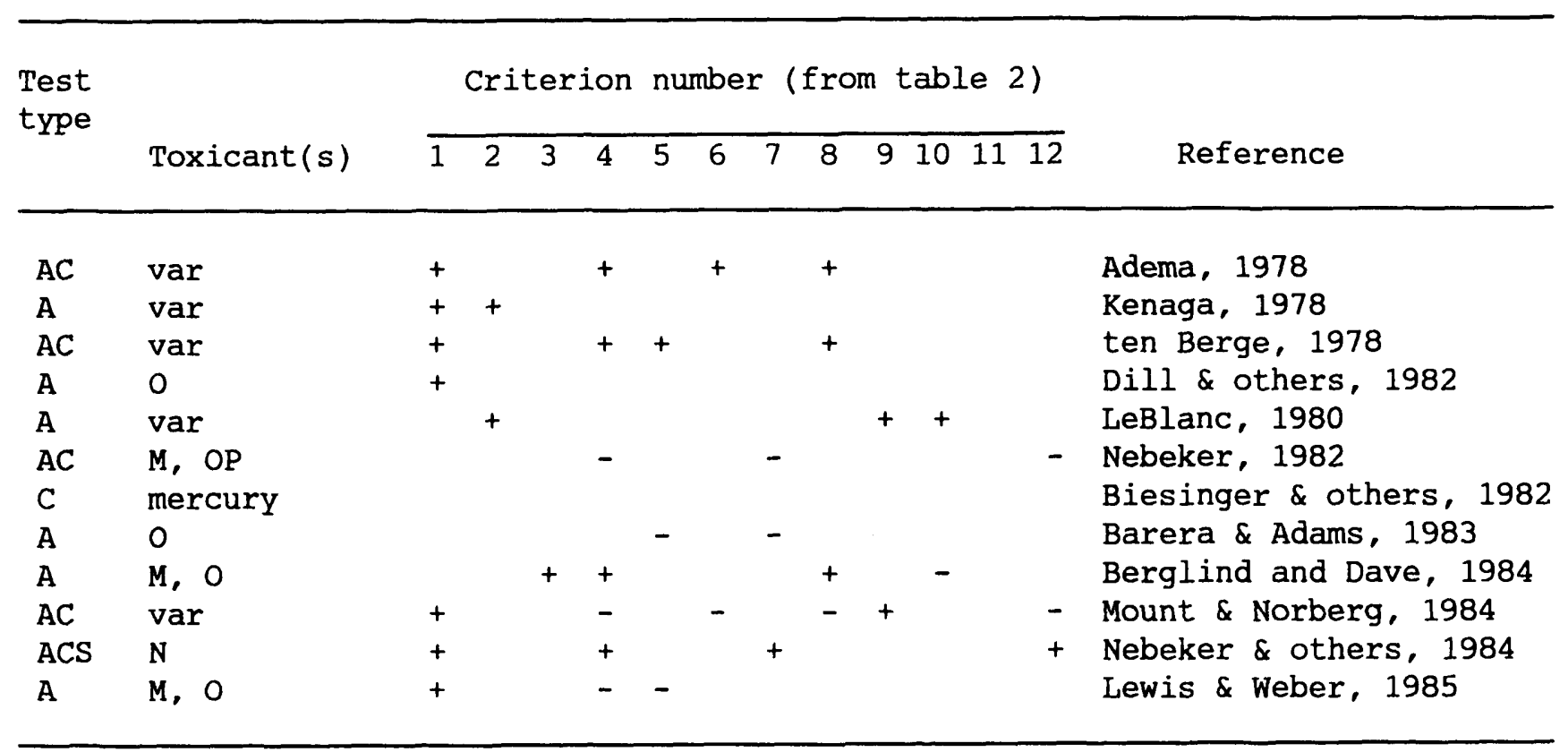


Table 8.--Cladocerans, excluding Daphnia magna

[D. = Daphnia; C. $=$ Ceriodaphnia $]$

\begin{tabular}{|c|c|c|c|c|c|c|c|c|c|c|c|c|c|}
\hline \multirow[b]{2}{*}{ Species } & \multirow{2}{*}{$\begin{array}{l}\text { Test } \\
\text { type }\end{array}$} & \multirow[b]{2}{*}{ Toxicant(s) } & \multicolumn{10}{|c|}{ Criterion number (from table 2) } & \multirow[b]{2}{*}{ Reference } \\
\hline & & & 1 & 2 & 3 & 4 & 5 & 6 & 7 & 8 & 91011 & 12 & \\
\hline D. pulex & $\mathbf{A}$ & var & + & + & & & & & & & & & Kenaga, 1978 \\
\hline var & $\mathbf{A}$ & var & + & & & + & + & + & & & & & Leeuwangh, 1978 \\
\hline var & $\mathbf{A}$ & $\mathrm{Cr}$ & & & + & + & - & + & & & ++ & + & Lee \& Buikema, 1979 \\
\hline Daphnia spp. & $\mathrm{AC}$ & var & + & & & - & & & - & & & - & Buikema \& others, 1980 \\
\hline D. pulicaria & A & 0 & - & & & & & & & & & & DeGraeve and others, 1980 \\
\hline C. reticulata & C & var & + & & & + & & & + & & & + & Mount \& Norberg, 1984 \\
\hline D. laevis & A & $\mathrm{OP}$ & & & & & & + & & & & & Foran and others, 1985 \\
\hline D. pulex & A & $\mathrm{M}, \mathrm{O}$ & + & & & - & - & & & & & & Lewis \& Weber, 1985 \\
\hline c. reticulata & A & $M, 0$ & + & & & & & & & & & & Elnabarawy \& others, 1986 \\
\hline
\end{tabular}

Table 9.--Pimephales promelas (fathead minnows)

\begin{tabular}{|c|c|c|c|c|c|c|c|c|c|c|c|c|}
\hline \multirow{2}{*}{$\begin{array}{l}\text { Test } \\
\text { type }\end{array}$} & \multirow[b]{2}{*}{ Toxicant(s) } & \multicolumn{10}{|c|}{ Criterion number (from table 2) } & \multirow[b]{2}{*}{ Reference } \\
\hline & & 1 & 2 & 3 & 4 & 5 & 6 & 7 & 8 & 910111 & 12 & \\
\hline AC & $M, 0$ & & & + & + & & & & & & & Adelman \& Smith, 1976 \\
\hline C & var & + & & & & + & & & & & + & McKim, 1977 \\
\hline $\mathbf{A}$ & 0 & + & & & & & & & & ++ & & Spehar \& others, 1982 \\
\hline A & E & + & + & & & & + & & & & & Keefe \& others, 1983 \\
\hline C & toluene & + & & & + & & + & & & + & & Devlin \& others, 1985 \\
\hline C & $\mathrm{E}$ & + & & & + & & + & + & & + & + & Norberg and Mount, $1985 a$ \\
\hline
\end{tabular}


Table 10.--Fish, excluding Pimephales promelas

\begin{tabular}{|c|c|c|c|c|c|c|c|c|c|}
\hline & \multirow{2}{*}{$\begin{array}{l}\text { Test } \\
\text { type }\end{array}$} & \multirow[b]{2}{*}{ Toxicant(s) } & \multicolumn{6}{|c|}{ Criterion number (from table 2) } & \multirow[b]{2}{*}{ Reference } \\
\hline & & & 1 & 2 & 34 & 5 & 67 & $\begin{array}{lllll}8 & 9 & 10 & 11 & 12\end{array}$ & \\
\hline Rainbow trout & $\mathbf{B}$ & var & + & + & & & & & Renaga, 1978 \\
\hline Salmonids (various) & B & M & & & & & + & & Davies \& Woodling, 1980 \\
\hline Rainbow trout & B & phenolics & + & & & & & & DeGraeve and others, 1980 \\
\hline Bluegill & $\mathrm{C}$ & var & & & + & & & ++ & van der Schalie, 1980 \\
\hline Rainbow trout & $\mathbf{A}$ & 0 & + & & & & & & Dill \& others, 1982 \\
\hline Bluegill & A & $E$ & + & + & & & + & & Keefe \& others, 1983 \\
\hline
\end{tabular}

Results in tables 5-10 indicate that certain criteria for test-species selection were considered much more frequently than others. Sensitivity (criterion \#1) was nearly always considered. Other factors, such as responsedetection capability (criterion \#3) or biological-uptake activity (criterion \#11) were infrequently discussed. This interferes with a balanced view of the strengths and weaknesses of each species. Whatever the species selected, different authors tend to give the same reasons for their selection, although there may be other important reasons that were not considered or mentioned.

The data for bacteria (table 5) are especially abundant largely because this methodology has been developing rapidly and advantages are often discussed in support of this development. If table 5 represents an accurate appraisal of bacterial techniques, it is apparent why bacteria are attracting more users. There was almost unanimous consensus that an important reason for using a bacteria test method is simplicity and rapidity (criterion \#7). Low cost (criterion \#12) is also frequently mentioned. of greater significance, however, is the frequency with which the first two criteria (sensitivity and representativeness) were given as advantages of bacteria tests. Investigations that compare the sensitivities of bacteria tests with those of eucaryotic species almost invariably show inferior sensitivity of bacteria. Nevertheless, many authors reported bacterial sensitivities for specific applications that are comparable to, or better than, those of other organisms.

The frequent consideration of sensitivity in selecting a test species is especially intriguing. Sensitivity was often given as an advantage of the species chosen, regardless of what species it was, in spite of evidence (discussed later in this report) of wide discrepancies among species in their sensitivities to specific substances. The apparent contradictions illustrate that sensitivity evaluations should be cast in terms of the toxic agents in question and relative sensitivity compared to that of other species. 
Daphnia magna, for example, has been shown to be one of the most sensitive of common test species for most metals. However, it is not very sensitive to organic compounds, and its sensitivity varies considerably among different classes of organics. Whatever the toxicant, the sensitivity of Daphnia magna is largely based on comparison with sensitivities of other species to the same toxicant. The outcome of this comparison is clearly dependent on the species with which Daphnia is compared.

The lessons from the sensitivity data in tables 5-10, therefore, are (1) sensitivity is toxicant dependent, and (2) sensitivity is usually assessed by comparing to sensitivity of other species rather than by comparing to some absolute scale based on expected toxicant concentrations in nature. Every species listed in table 3 has been selected as a toxicity-test organism largely because its sensitivity was judged better than that of many other species, at least for some toxicants. Thus the large number of favorable marks for criterion 1 in tables 5-10 should not be interpreted as indications of good overall sensitivity to different types of toxicants or of good sensitivity to any particular toxicant at naturally occurring or even maximum allowable concentrations.

\section{Acute Sensitivities of Test Species}

Sensitivity is the primary factor that determines the usefulness of a test species (table 2). However, it is not a simple matter to select the most sensitive indicator organism for every test situation. It is especially difficult for ambient tests where the test substance may contain several toxic agents. Not only is sensitivity dependent on the toxic agent, but there is little information available to evaluate the relative sensitivities of species to specific agents. This is especially true for chronic tests because of the wide variety of monitoring procedures and endpoints.

Some data have been compiled in tables 11-19 to compare acute sensitivities of different species to certain organic compounds and metals in water. Despite the fact that methods and test conditions vary, single-species acute toxicity tests provide data in a standard format for specific toxic agents. Other kinds of tests do not produce this kind of comparable information. Therefore, chronic test results, or results from studies that were done with ambient substances or variable mixtures of substances (such as leachates or effluents) could not be included. 
Tables 11-14.--Acute toxicities of selected organic compounds

to various test species

[All values in milligrams per liter. Species listed in decreasing order of reported sensitivity (increasing order of concentrations needed to reach endpoint). When ranges of endpoint concentrations were reported by authors, only median or mean values are reported here. Endpoint for animal species is 50-percent mortality in specified exposure time period unless otherwise indicated. Endpoint for bacteria species is 50-percent reduction in measured activity (usually luminescence or mobility) in specified exposure time period. Endpoint for phytoplankton species is 50-percent reduction in growth rate (usually measured as $\mathrm{C}-14$ uptake or oxygen production.]

Table 11.-- $\underline{\text { Phenol }}$

[ $\mathrm{h}=$ hours, $\mathrm{m}=$ minutes $]$

\begin{tabular}{|c|c|c|c|}
\hline Species & $\begin{array}{l}\text { Exposure } \\
\text { time }\end{array}$ & $\begin{array}{l}\text { Endpoint } \\
\text { concentration } \\
\text { (milligrams } \\
\text { per liter) }\end{array}$ & Reference \\
\hline
\end{tabular}

Daphnia magna

Daphnia magna

Photobacterium phosphoreum

Photobacterium phosphoreum

Photobacterium phosphoreum

Photobacterium phosphoreum

Photobacterium phosphoreum

Daphnia magna

Photobacterium phosphoreum

photobacterium phosphoreum

Photobacterium phosphoreum

Pimephales promelas

Daphnia pulicaria

Pseudomonas putida

$\begin{array}{cc}48 \mathrm{~h} & 6.6 \\ 48 \mathrm{~h} & 12 \\ 5 \mathrm{~m} & 22 \\ 5 \mathrm{~m} & 25 \\ 5 \mathrm{~m} & 25 \\ 5 \mathrm{~m} & 26 \\ 5 \mathrm{~m} & 28 \\ 48 \mathrm{~h} & 30 \\ 15 \mathrm{~m} & 34 \\ 5 \mathrm{~m} & 39.5 \\ 5 \mathrm{~m} & 40.2 \\ 96 \mathrm{~h} & 67.5 \\ 48 \mathrm{~h} & >109 \\ 6 \mathrm{~h} & 244\end{array}$

Keen and Baillod, 1985

LeBlanc, 1980

Qureshi and others, 1982

Lebsack and others, 1981

Bulich and others, 1981

Chang and others, 1981

Dutka and others, 1983

Bobra and others, 1983

Dutka and Kwan, 1981

McFeters and others, 1983

Curtis and others, 1982

DeGraeve and others, 1980

DeGraeve and others, 1980

Slabbert, 1986 
Table 12.--Pentachlorophenol

[ $\mathrm{h}=$ hours, $\mathrm{m}=$ minutes $]$

\begin{tabular}{|c|c|c|c|}
\hline Species & $\begin{array}{c}\text { Exposure } \\
\text { time }\end{array}$ & $\begin{array}{l}\text { Endpoint } \\
\text { concentration } \\
\text { (milligrams } \\
\text { per liter) }\end{array}$ & Reference \\
\hline Ictalurus punctatus (catfish) & $96 \mathrm{~h}$ & 0.053 & Phipps and Holcombe, 1985 \\
\hline Photobacterium phosphoreum & $5 \mathrm{~m}$ & .08 & Curtis and others, 1982 \\
\hline$\overline{\text { Salmo gairdner } i}$ & $96 \mathrm{~h}$ & .093 & McKim and others, $1987(a)$ \\
\hline$\overline{\text { Nais communis }}$ & $96 \mathrm{~h}$ & .11 & Chapman and Mitchell, 1986 \\
\hline$\overline{\text { Salmo gairdneri }}$ & $96 \mathrm{~h}$ & .115 & Thurston and others, 1985 \\
\hline Lepomis macrochirus & $96 \mathrm{~h}$ & .14 & Phipps and Holcombe, 1985 \\
\hline$\overline{\text { Daphnia }} \overline{\text { magna }}$ & $48 \mathrm{~h}$ & .143 & Mount and Norberg, 1984 \\
\hline$\overline{\text { Daphnia }} \overline{\text { magna }}$ & $48 \mathrm{~h}$ & .145 & Thurston and others, 1985 \\
\hline Carassius auratus (goldfish) & $96 \mathrm{~h}$ & .16 & Phipps and Holcombe, 1985 \\
\hline Ceriodaphnia reticulata & $48 \mathrm{~h}$ & .164 & Mount and Norberg, 1984 \\
\hline$\overline{\text { Carassius auratus }}$ & $96 \mathrm{~h}$ & .190 & Adeleman and others, 1976 \\
\hline$\overline{\text { Salmo trutta }}$ & $24 \mathrm{~h}$ & .2 & Hattula and others, 1981 \\
\hline$\overline{\text { Lepomis macrochirus }}$ & $96 \mathrm{~h}$ & .202 & Thurston and others, 1985 \\
\hline Pimephales promelas & $96 \mathrm{~h}$ & .203 & Adeleman and others, 1976 \\
\hline Daphnia pulex & $48 \mathrm{~h}$ & .246 & Mount and Norberg, 1984 \\
\hline Pimephales promelas & $96 \mathrm{~h}$ & .25 & Phipps and Holcombe, 1985 \\
\hline$\overline{\text { Carassius auratus }}$ & $96 \mathrm{~h}$ & .264 & Thurston and others, 1985 \\
\hline Pimephales promelas & $96 \mathrm{~h}$ & .266 & Thurston and others, 1985 \\
\hline Ilyodrilus frantzi & $96 \mathrm{~h}$ & .31 & Chapman and Mitchell, 1986 \\
\hline$\overline{\text { Daphnia magna }}$ & $48 \mathrm{~h}$ & .33 & Lewis and Weber, 1985 \\
\hline Limnodrilus hoffmeisteri & $96 \mathrm{~h}$ & .33 & Chapman and others, 1982 \\
\hline Tubifex tubifex & $96 \mathrm{~h}$ & .38 & Chapman and others, 1982 \\
\hline$\overline{\text { Daphnia }} \overline{\text { pulex }}$ & $48 \mathrm{~h}$ & .39 & Lewis and Weber, 1985 \\
\hline Photobacterium phosphoreum & $5 \mathrm{~m}$ & .5 & Bulich and others, 1981 \\
\hline$\overline{\text { Daphnia magna }}$ & $48 \mathrm{~h}$ & .68 & LeBlanc, 1980 \\
\hline Photobacterium phosphoreum & $15 \mathrm{~m}$ & .76 & De Zwart and Sloof, 1983 \\
\hline Photobacterium phosphoreum & $5 \mathrm{~m}$ & .94 & De Zwart and Sloof, 1983 \\
\hline Tanytarsus dissimilis & $48 \mathrm{~h}$ & 25.2 & Thurston and others, 1985 \\
\hline Pseudomonas fluorescens & $1 \mathrm{~h}$ & 29.2 & Trevors and others, 1982 \\
\hline Orconectes immunis & $96 \mathrm{~h}$ & 183 & Thurston and others, 1985 \\
\hline
\end{tabular}


Table 13.-- Benzene

[ $\mathrm{h}=$ hours, $\mathrm{m}=$ minutes $]$

\begin{tabular}{|c|c|c|c|}
\hline Species & $\begin{array}{l}\text { Exposure } \\
\text { time }\end{array}$ & $\begin{array}{l}\text { Endpoint } \\
\text { concentration } \\
\text { (milligrams } \\
\text { per liter) }\end{array}$ & Reference \\
\hline Photobacterium phosphoreum & $5 \mathrm{~m}$ & 2.0 & Bulich and others, 1981 \\
\hline Photobacterium phosphoreum & $5 \mathrm{~m}$ & 4.11 & McFeters and others, 1983 \\
\hline Daphnia magna & $48 \mathrm{~h}$ & 31.3 & Bobra and others, 1983 \\
\hline Photobacterium phosphoreum & $5 \mathrm{~m}$ & 200 & Chang and others, 1981 \\
\hline Daphnia magna & $48 \mathrm{~h}$ & 200 & LeBlanc, 1980 \\
\hline Photobacterium phosphoreum & $5 \mathrm{~m}$ & 214 & De Zwart and Sloof, 1983 \\
\hline Photobacterium phosphoreum & $5 \mathrm{~m}$ & 238 & De Zwart and Sloof, 1983 \\
\hline
\end{tabular}

Table 14.--Toluene

[ $\mathrm{h}=$ hours, $\mathrm{m}=$ minutes $]$

Species $\quad \begin{gathered}\text { Endpoint } \\ \text { Exposure } \\ \text { time }\end{gathered} \quad \begin{gathered}\begin{array}{c}\text { Encentration } \\ \text { (milligrams } \\ \text { per liter) }\end{array} \\ \text { Reference }\end{gathered}$

Daphnia magna

Pimephales promelas (30-d) $96 \mathrm{~h}$

Photobacterium phosphoreum $5 \mathrm{~m}$

Pimephales promelas

(embryos)

Dapnia magna

Photobacterium phosphoreum
$48 \mathrm{~h}$

$96 \mathrm{~h}$

11.5

26

50

63

$48 \mathrm{~h}$

$5 \mathrm{~m}$
310

33,833
Bobra and others, 1983

Devlin and others, 1982

Chang and others, 1981

Devlin and others, 1982

LeBlanc, 1980

McFeters and others, 1983 
Tables 15-19.--Acute toxicities of selected metals to various test species

[All values in milligrams per liter. Species listed in decreasing order of reported sensitivity (increasing order of concentrations needed to reach endpoint). When ranges of endpoint concentrations were reported by authors, only median or mean values are reported here. Endpoint for animal species is 50-percent mortality in specified exposure time period unless otherwise indicated. Endpoint for bacteria species is 50-percent reduction in measured activity (usually luminescence or mobility) in specified exposure time period. Endpoint for phytoplankton species is 50-percent reduction in growth rate (usually measured as C-14 uptake or oxygen production.] 
Table 15.--Copper

[ $\mathrm{h}=$ hours, $\mathrm{m}=$ minutes $]$

\begin{tabular}{lcc}
\hline Exposure & $\begin{array}{c}\text { Endpoint } \\
\text { concentration } \\
\text { (milligrams } \\
\text { per liter) }\end{array}$ & Reference \\
\hline
\end{tabular}

\begin{tabular}{|c|c|c|c|}
\hline Ceriodaphnia reticulata & $48 \mathrm{~h}$ & 0.017 & Mount and Norberg, 1984 \\
\hline$\overline{\text { Daphnia magna }}$ & $48 \mathrm{~h}$ & .02 & Qureshi and others, 1982 \\
\hline$\frac{\text { Corbicula manilensis }}{\text { (veliger larvae) }}$ & $24 \mathrm{~h}$ & .028 & Harrison and others, 1984 \\
\hline Corbicula fluminea & $96 \mathrm{~h}$ & .04 & Rodgers and others, 1980 \\
\hline Daphnia pulex & $48 \mathrm{~h}$ & .053 & Mount and Norberg, 1984 \\
\hline Daphnia magna & $48 \mathrm{~h}$ & .054 & Mount and Norberg, 1984 \\
\hline Selenastrum capricornutum & & .054 & Turbak and others, 1986 \\
\hline Chlorella stigmatophora & & .07 & Christensen and others, 1979 \\
\hline Selenastrum capricornutum & & .07 & Bartlett and others, 1974 \\
\hline Selenastrum capricornutum & & .085 & Christensen and others, 1979 \\
\hline Lumbriculus variegatus & $96 \mathrm{~h}$ & .15 & Bailey and Liu, 1980 \\
\hline Lumbriculus variegatus & $48 \mathrm{~h}$ & .23 & Bailey and Liu, 1980 \\
\hline Salmo gairdneri & $96 \mathrm{~h}$ & .25 & Qureshi and others, 1982 \\
\hline$\frac{\text { Chironomus }}{\text { (1st instantans }}$ & $96 \mathrm{~h}$ & .30 & $\begin{array}{c}\text { Nebeker, Cairns, and Wise, } \\
1984\end{array}$ \\
\hline Corbicula fluminea & $24 \mathrm{~h}$ & .59 & Rodgers and others, 1980 \\
\hline Lepomis macrochirus & $96 \mathrm{~h}$ & 1.0 & Thompson and others, 1980 \\
\hline$\overline{\text { Pseudomonas putida (bact.) }}$ & $6 \mathrm{~h}$ & 1.05 & Slabbert, 1986 \\
\hline$\frac{\text { Crangonyx }}{\text { (amphipod) }}$ & $96 \mathrm{~h}$ & 1.29 & Martin and Holdick, 1986 \\
\hline$\frac{\text { Corbicula manilensis }}{(\text { adult })}$ & $96 \mathrm{~h}$ & 2.6 & Harrison and others, 1984 \\
\hline Photobacterium phosphoreum & $15 \mathrm{~m}$ & 3.8 & Dutka and Kwan, 1981 \\
\hline Spirillum voluntans & $5 \mathrm{~m}$ & 7.4 & Qureshi and others, 1982 \\
\hline Photobacterium phosphoreum & $5 \mathrm{~m}$ & 7.4 & Qureshi and others, 1982 \\
\hline Photobacterium phosphoreum & $5 \mathrm{~m}$ & 8.0 & Bulich and others, 1981 \\
\hline$\frac{\text { Asellus }}{\text { (amphipod) }}$ & $96 \mathrm{~h}$ & 9.21 & Martin and Holdich, 1986 \\
\hline Photobacterium phosphoreum & $5 \mathrm{~m}$ & 25 & McFeters and others, 1983 \\
\hline
\end{tabular}


Table 16.--Cadmium

[ $\mathrm{h}=$ hours, $\mathrm{m}=$ minutes $]$

\begin{tabular}{|c|c|c|c|}
\hline Species & $\begin{array}{l}\text { Exposure } \\
\text { time }\end{array}$ & $\begin{array}{l}\text { Endpoint } \\
\text { concentration } \\
\text { (milligrams } \\
\text { per liter) }\end{array}$ & Reference \\
\hline Salmo gairdneri & $96 \mathrm{~h}$ & 0.003 & Phipps and Holcombe, 1985 \\
\hline$\overline{\text { Daphnia magna }}$ & $48 \mathrm{~h}$ & .053 & Lewis and Weber, 1985 \\
\hline Selenastrum capricornutum & & .057 & Turbak and others, 1986 \\
\hline$\overline{\text { Selenastrum capricornutum }}$ & & .06 & Bartlett and others, 1974 \\
\hline Ceriodaphnia reticulata & $48 \mathrm{~h}$ & .066 & Mount and Norberg, 1984 \\
\hline$\overline{\text { Daphnia pulex }}$ & $48 \mathrm{~h}$ & .068 & Mount and Norberg, 1984 \\
\hline Lumbriculus variegatus & $96 \mathrm{~h}$ & .074 & Bailey and Liu, 1980 \\
\hline$\overline{\text { Daphnia magna }}$ & $48 \mathrm{~h}$ & .118 & Mount and Norberg, 1984 \\
\hline$\overline{\text { Lumbriculus variegatus }}$ & $48 \mathrm{~h}$ & .12 & Bailey and Liu, 1980 \\
\hline$\overline{\text { Gammarus pulex }}$ & $96 \mathrm{~h}$ & .12 & Wright and Frain, 1981 \\
\hline Limnodrilus hoffmeisteri & $96 \mathrm{~h}$ & .17 & Chapman and others, 1982 \\
\hline Tubifex tubifex & $96 \mathrm{~h}$ & .32 & Chapman and others, 1982 \\
\hline Gammarus pulex & $48 \mathrm{~h}$ & .68 & Wright and Frain, 1981 \\
\hline Pseudomonas putida (bact.) & $6 \mathrm{~h}$ & .72 & Slabbert, 1986 \\
\hline$\overline{\text { Carassius auratus }}$ & $96 \mathrm{~h}$ & .748 & Phipps and Holcombe, 1985 \\
\hline$\frac{\overline{\text { Asellus }}}{\text { (amphipod) }}$ & $96 \mathrm{~h}$ & 1.32 & Martin and Holdich, 1986 \\
\hline Pimephales promelas & $96 \mathrm{~h}$ & 1.5 & Phipps and Holcombe, 1985 \\
\hline$\frac{\overline{\text { Crangonyx }}}{\text { (amphipod) }}$ & $96 \mathrm{~h}$ & 1.70 & Martin and Holdich, 1986 \\
\hline Ictalurus punctatus & $96 \mathrm{~h}$ & 4.48 & Phipps and Holcombe, 1985 \\
\hline Lepomis macrochirus & $96 \mathrm{~h}$ & 6.47 & Phipps and Holcombe, 1985 \\
\hline Photobacterium phosphoreum & $15 \mathrm{~m}$ & 218 & De Zwart and Sloof, 1983 \\
\hline Photobacterium phosphoreum & $5 \mathrm{~m}$ & 416 & McFeters and others, 1983 \\
\hline Photobacterium phosphoreum & $5 \mathrm{~m}$ & 1,070 & De Zwart and Sloof, 1983 \\
\hline
\end{tabular}




$$
\begin{gathered}
\text { Table } 17 .--\underline{\text { zinc }} \\
{[\mathrm{d}=\text { days }, \mathrm{h}=\text { hours, } \mathrm{m}=\text { minutes }]}
\end{gathered}
$$

\begin{tabular}{|c|c|c|c|}
\hline Species & $\begin{array}{l}\text { Exposure } \\
\text { time }\end{array}$ & $\begin{array}{l}\text { Endpoint } \\
\text { concentration } \\
\text { (milligrams } \\
\text { per liter) }\end{array}$ & Reference \\
\hline
\end{tabular}

\begin{tabular}{|c|c|c|c|}
\hline Selenastrum capricornutum & & 0.051 & Turbak and others, 1986 \\
\hline Daphnia magna & $48 \mathrm{~h}$ & .068 & Mount and Norberg, 1984 \\
\hline Ceriodaphnia reticulata & $48 \mathrm{~h}$ & .076 & Mount and Norberg, 1984 \\
\hline$\overline{\text { Daphnia pulex }}$ & $48 \mathrm{~h}$ & .107 & Mount and Norberg, 1984 \\
\hline Salmo gairdneri & $14 \mathrm{~d}$ & .41 & Nehring and Goett1, 1974 \\
\hline$\overline{\text { Salmo }} \overline{\text { trutta }}$ & $14 \mathrm{~d}$ & .64 & Nehring and Goettl, 1974 \\
\hline$\overline{\text { Salmo }} \overline{\text { clarki }}$ & $14 \mathrm{~d}$ & .67 & Nehring and Goettl, 1974 \\
\hline$\overline{\text { Selenastrum }}$ capricornutum & & .7 & Bartlett and others, 1974 \\
\hline$\overline{\text { Salvelinus }}$ fontinalis & $14 \mathrm{~d}$ & .96 & Nehring and Goettl, 1974 \\
\hline$\overline{\text { Salmo gairdneri }}$ & $96 \mathrm{~h}$ & 2.2 & Qureshi and others, 1982 \\
\hline Photobacterium phosphoreum & $5 \mathrm{~m}$ & 2.5 & Bulich and others, 1981 \\
\hline Photobacterium phosphoreum & $15 \mathrm{~m}$ & 3.5 & Dutka and Kwan, 1981 \\
\hline Daphnia magna & $48 \mathrm{~h}$ & 5.1 & Qureshi and others, 1982 \\
\hline Corbicula fluminea & $96 \mathrm{~h}$ & 6.04 & Rodgers and others, 1980 \\
\hline Lumbriculus variegatus & $96 \mathrm{~h}$ & 6.3 & Bailey and Liu, 1980 \\
\hline$\overline{\text { Pseudomonas }}$ putida (bact.) & $6 \mathrm{~h}$ & 7.15 & slabbert, 1986 \\
\hline Spirillum voluntans & $5 \mathrm{~m}$ & 7.2 & Qureshi and others, 1982 \\
\hline Lumbriculus variegatus & $48 \mathrm{~h}$ & 8.1 & Bailey and Liu, 1980 \\
\hline$\overline{\frac{\text { Asellus }}{\text { (amphipod) }}}$ & $96 \mathrm{~h}$ & 18.2 & Martin and Holdich, 1986 \\
\hline$\frac{\text { Crangonyx pseudogracilis }}{\text { (amphipod) }}$ & $96 \mathrm{~h}$ & 19.8 & Martin and Holdich, 1986 \\
\hline Corbicula fluminea & $24 \mathrm{~h}$ & $>40$ & Rodgers and others, 1980 \\
\hline Photobacterium phosphoreum & $5 \mathrm{~m}$ & 49 & Qureshi and others, 1982 \\
\hline photobacterium phosphoreum & $5 \mathrm{~m}$ & 477 & McFeters and others, 1983 \\
\hline
\end{tabular}


Table 18.--Mercury

[ $\mathrm{h}=$ hours, $\mathrm{m}=$ minutes $]$

\begin{tabular}{|c|c|c|c|}
\hline Species & $\begin{array}{l}\text { Exposure } \\
\text { time }\end{array}$ & $\begin{array}{l}\text { Endpoint } \\
\text { concentration } \\
\text { (milligrams } \\
\text { per liter) }\end{array}$ & Reference \\
\hline$\frac{\text { Crangonyx }}{\text { (amphipod) }}$ & $96 \mathrm{~h}$ & 0.001 & Martin and Holdich, 1986 \\
\hline Daphnia magna & $48 \mathrm{~h}$ & .03 & Qureshi and others, 1986 \\
\hline Photobacterium phosphoreum & $15 \mathrm{~m}$ & .044 & De Zwart and Sloof, 1983 \\
\hline Photobacterium phosphoreum & $5 \mathrm{~m}$ & .051 & De Zwart and Sloof, 1983 \\
\hline Photobacterium phosphoreum & $5 \mathrm{~m}$ & .06 & McFeters and others, 1983 \\
\hline Photobacterium phosphoreum & $5 \mathrm{~m}$ & .065 & Bulich and others, 1981 \\
\hline Photobacterium phosphoreum & $5 \mathrm{~m}$ & .08 & Qureshi and others, 1982 \\
\hline Lumbriculus variegatus & $96 \mathrm{~h}$ & .10 & Bailey and Liu, 1980 \\
\hline Lumbriculus variegatus & $48 \mathrm{~h}$ & .11 & Bailey and Liu, 1980 \\
\hline Tubifex tubifex & $96 \mathrm{~h}$ & .14 & Chapman and others, 1982 \\
\hline$\overline{\text { Nais communis }}$ & $96 \mathrm{~h}$ & .16 & Chapman and Mitchell, 1986 \\
\hline Limnodrilus hoffmeisteri & $96 \mathrm{~h}$ & .18 & Chapman and others, 1982 \\
\hline$\frac{\text { Asellus }}{\text { (amphipod) }}$ & $96 \mathrm{~h}$ & .20 & Martin and Holdich, 1986 \\
\hline Salmo gairdneri & $96 \mathrm{~h}$ & .21 & Qureshi and others, 1982 \\
\hline Ilyodrilus frantzi & $96 \mathrm{~h}$ & .29 & Chapman and Mitchell, 1986 \\
\hline$\overline{\text { Spirillum voluntans }}$ & $5 \mathrm{~m}$ & 3.7 & Qureshi and others, 1982 \\
\hline
\end{tabular}




$$
\begin{gathered}
\text { Table 19.-- Lead } \\
{[\mathrm{h}=\text { hours, } \mathrm{m}=\text { minutes }]}
\end{gathered}
$$

\begin{tabular}{|c|c|c|c|}
\hline Selenastrum capricornutum & & 0.14 & Christensen and others, 1979 \\
\hline Ceriodaphnia reticulata & $48 \mathrm{~h}$ & .53 & Mount and Norberg, 1984 \\
\hline Chlorella stigmatophora & & .70 & Christensen and others, \\
\hline Lumbriculus variegatus & $96 \mathrm{~h}$ & 1.8 & Bailey and Liu, 1980 \\
\hline Lumbriculus variegatus & $48 \mathrm{~h}$ & 3.4 & Bailey and Liu, 1980 \\
\hline Daphnia magna & $48 \mathrm{~h}$ & 4.4 & Mount and Norberg, 1984 \\
\hline$\overline{\text { Daphnia pulex }}$ & $48 \mathrm{~h}$ & 5.1 & Mount and Norberg, 1984 \\
\hline$\frac{\text { Crangonyx }}{\text { (amphipod) }}$ & $96 \mathrm{~h}$ & 27.6 & Martin and Holdich, 1986 \\
\hline Photobacterium phosphoreum & $15 \mathrm{~m}$ & 30 & Dutka and Kwan, 1981 \\
\hline$\frac{\text { Asellus }}{\text { (amphipod) }}$ & $96 \mathrm{~h}$ & 64.1 & Martin and Holdich, 1986 \\
\hline
\end{tabular}

Species $\begin{array}{ccc}\text { Exposure } & \begin{array}{c}\text { Endpoint } \\ \text { concentration } \\ \text { time }\end{array} & \begin{array}{c}\text { (milligrams } \\ \text { per liter) }\end{array}\end{array} \quad$ Reference

The endpoint for all animal species was mortality, and the results were reported as LC50 in milligrams per liter. There was some variation in exposure time but, in most cases, it was 96 hours for $\mathrm{fish}, 48$ hours for cladocerans, and either 48 or 96 hours for other invertebrates. For bacteria, the endpoint was 50-percent reduction in luminescence, and for algae, it was 50-percent reduction in growth or production. Although different than mortality, these standardized endpoints for bacteria and algae are well established and may be compared with animal LC50's for the purpose of comparing sensitivities.

The data in tables 11-17 indicate some patterns of sensitivity among different species, and they also raise some questions. Bacteria are apparently sensitive to organics under some conditions, but they are much less useful for testing metal toxicity. Mercury is a possible exception; it produces responses in Photobacterium phosphoreum at relatively low concentrations (table 18). Cladocerans are generally among the most sensitive species to metals. Some of the less commonly used invertebrates, such as Corbicula species and some of the amphipods and oligochaetes, show relatively high sensitivity to some substances.

Among the peculiarities shown by the tables are the wide ranges of sensitivities, even within a single species. For example, there was a 100fold range in sensitivity to benzene by photobacterium phosphoreum in different studies (table 13). A similar range appeared in the sensitivity of Daphnia magna to toluene (table 14 ), and the overall range in sensitivity to 
toluene was nearly 3,000-fold among just 6 studies. Fish species are generally considered especially good indicators for organic contaminants, but this contention is not strongly supported by tables 11-14. None of the tables reveal a clearly superior species in terms of its sensitivity to that substance.

Another disturbing aspect of sensitivity revealed by tables $11-19$ is that even the best sensitivities shown are not indicative of truly useful bioindicators. The lowest concentrations shown for each of the toxicants represented are higher than any that would be encountered in most aquatic systems, except for highly contaminated waters. An illustration of this point is shown in figure 2. The LC50 values for copper, cadmium, zinc, mercury, and lead are taken from tables 15-19. Thus, they represent lethal concentrations in various acute tests, using different test species. The actual concentration data, shown by the histogram, shows the maximum total concentrations of the same metals in some sites around the country that have been monitored by the USGS for several years. These sites are subject to inputs from various industrial, agricultural, or municipal sources and may be expected to contain higher metal concentrations than most natural waters. Nevertheless, the maximum concentrations reported from these sites are nearly all lower than the LC50 values shown and, in many cases, they are lower by a factor of 10 or more. Although sublethal effects or lower-percentage mortality may occur at lower concentrations than the LC50 values shown in figure 2, these data cast serious doubt that most current test procedures would have adequate sensitivity to reveal long-term toxicant conditions in ambient waters.

Figure 2 also compares LC50 data with water-quality criteria established by the Environmental Protection Agency (U.S. Environmental Protection Agency, 1986). Acute criteria are concentrations likely to be detrimental to aquatic life if exceeded for a 1-hour period at least once during 3 years, on the average. Chronic criteria are concentrations likely to be detrimental to aquatic life if exceeded for a 4-day period at least once during 3 years, on the average. The acute criteria are lower than nearly all of the LC50 values given. The chronic criteria are even further below the detection ranges for the toxicity tests; they are less than LC50 values for all methods shown except zinc.

\section{Overview of Test-Species Selection}

The preceding discussion of test species and criteria for their selection does not lead to clear choices of species to use for a large-scale water-quality-assessment program or for any particular study within such a program. It does include information that would be considered before making species selections. The selections themselves would necessarily depend on conditions of the test and application requirements which would vary from study to study. 

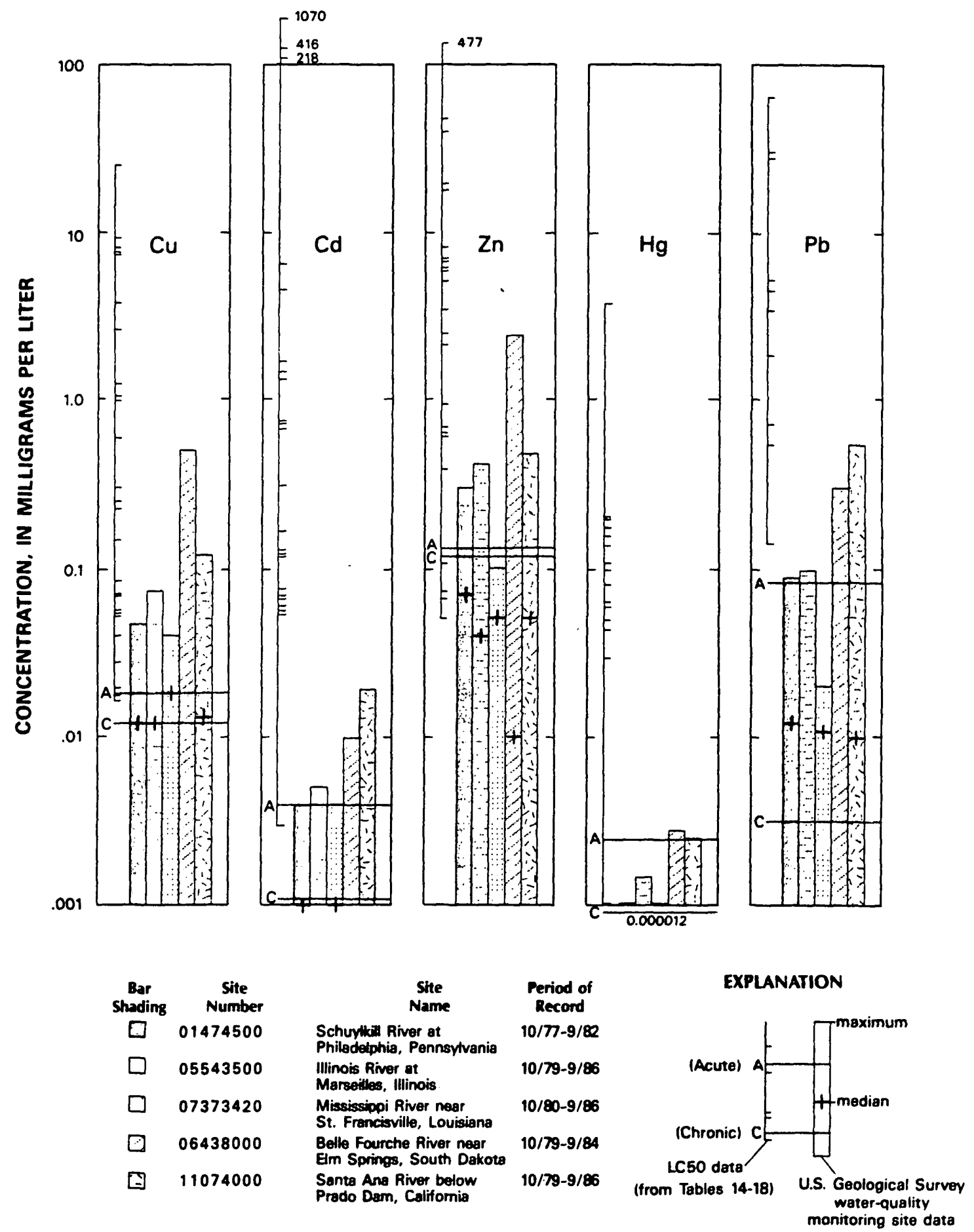

Figure 2. 50-percent lethal concentration and maxima and median concentration data for copper, cadmium, zinc, mercury, and lead in water from five selected U.S. Geological Survey water-qualitymonitoring sites and water-quality criteria. 
Certain criteria from table 2 are especially important for selection of procedures to investigate potential ambient toxicity problems over broad geographical areas. These include amenability to laboratory culture (item 4), reproducibility of results (5), simplicity of test (7), availability of background information (9), documented methodology (10), and low cost (12). All of these factors relate to the practicality of using the species in a standard fashion in a variety of different test waters, and/or to the interpretability and comparability of data obtained in this way. Presumably, therefore, these criteria would move up on the scale of relative importance in selecting test species for a national program.

Sensitivity (item 1) remains a very important criterion for test-species selection in large-scale ambient toxicity assessments. If the test is so insensitive that toxicity detection is not likely even with heavily contaminated samples, then it is of little use as a biomonitoring tool, regardless of its other attributes. Representativeness (item 2) also is a very important selection criterion if there is any expectation of analyzing the biological implications of contaminant occurrences.

The selection of test species should suit the stated purpose of the test. As an example, if rainbow trout is the key species in the study area that might be affected by a contaminant input, then rainbow trout would be the logical choice as a test species. Most selections are likely to be far less obvious, but consideration of the advantages and disadvantages of different test species should improve the likelihood of success.

In general, any toxicity-testing procedure that uses only one test species is not appropriate for determining effects of the broad array of contaminants that may be present over a large geographical area. Current status of toxicity-test methodology and information about sensitivities of test species used previously indicates that no single-species test has the general applicability and uniformly high sensitivity required for ambient toxicity testing on a regional or national scale. There are greater possibilities if more than one species can be used; more discussion of this option will follow.

\section{Acute and Chronic Tests}

One of the most important methodology decisions to be made in the design of a single-species test is whether testing should be done by acute lethality tests or chronic exposure tests.

In the acute test, the test organisms are exposed to relatively high concentrations of the contaminant, and the test is concluded in a short time (usually a few days). The common endpoint of such tests is mortality, measured as LC50, which is the minimum concentration that causes 50-percent mortality in the test organisms during a specified time period (usually 48 or 96 hours). The test is generally done with a single species in small

enclosures in a laboratory. In the simplest method, the "static" acute test, the medium and its toxicant content are not changed during the experiment. Alternatives to this method are the "static-renewal," "flow-through," or 
"continuous-flow" tests, in which the medium and its toxicant load are continually or periodically replenished as spent medium flows from the test enclosure.

The LC50 concept is relatively simple and is widely used. Lethality is an easily monitored endpoint, and LC50 provides a convenient, standardized and unambiguous format for reporting toxicities. However, it has been argued that LC50 is an arbitrary and meaningless standard that is irrelevant to the natural environment (White and Champ, 1984). Certainly, it is an indicator of the toxicity of a particular substance to a particular organism under the conditions of the test, but it is not at all clear what that means in terms of overall toxicity of the substance in the natural environment. Some reports show a good correlation between LC50 and measures of natural toxicant effects (Giddings and Franco, 1985; Mount and others, 1984), whereas others show a poor relation (Rodgers and others, 1980; Kimball and Levin, 1985). Numerous authors have cautioned against assumptions of community toxicity based on measurements with a single species or process (Dutka and others, 1983; Cairns, 1983; Blanck, 1984; Bowmer, 1986).

In the chronic test, the organisms are exposed to nonlethal concentrations over a relatively long period of time. Long-term exposure may produce some mortality, but the endpoint of the experiment is some sublethal response such as a decrease in growth rate, reduction of reproductive capacity, interference in mobility, or anatomical change. The results yield information about "effective" concentrations of the toxic agent rather than the lethal concentrations determined by acute tests. Sublethal responses might not occur during a short-term test. For example, Winner (1981) found effects of copper and zinc on longevity of Daphnia magna, but those effects did not appear until some 50-70 days after initiation of the experiment. Many chronic test endpoints can only be determined by monitoring the complete life cycle of the organism (Goodman and others, 1982). Such "life-cycle" tests must be continued for at least as long as one reproductive cycle. Chronic tests are potentially more informative than acute tests, not only because they avoid the problems of short, unrealistic exposures (Eaton, 1973), but also because more data are generated, allowing more rigorous statistical analysis (Brown, 1973).

A number of recent studies of the effects of toxicants on a variety of animal species have emphasized the improved sensitivity of chronic tests over acute tests (Eaton, 1973; Sprague, 1976; Winner and Farrell, 1976; Winner, 1981, Snarski and Olson, 1982; Hermens and others, 1984; Chapman and Brinkhurst, 1984; Chapman and others, 1985; and Norberg and Mount, 1985a). Sublethal responses may be observed at toxicant concentrations considerably lower than those that produce mortality of half of the population. However, this advantage of chronic testing must be weighed against the disadvantage that sublethal responses are often subtle and difficult to monitor. Inconsistent responses among different individuals of a population is a common problem in chronic tests (Geiger and Buikema, 1981). Furthermore, chronic tests may require complex experimental set-ups and long-term culturing of organisms. 
In part because of their sensitivity, chronic tests may produce more meaningful results than acute tests. Factors such as growth, fecundity, and feeding habits may be more significant indicators of contaminant impacts than is lethality at relatively high concentrations. This argument is based on the presumption that environmental contamination, even in extreme cases of pollution, will generally be lower than acute lethal levels, but will present the biota with long-term, low-level exposure. Hence, the effects are likely to be sublethal, but still may severely affect the community.

Despite the repeated claims of the advantages of the chronic test approach, the simplicity and precision of the acute tests are significant factors in their favor. The continued use of acute, single-species tests is assured by their applications for determining compliance of effluents with regulatory standards. Macek and others (1978) reported that the consensus among attendees at a 1976 Workshop on Application of Aquatic Toxicity Methodology was that acute lethality tests are the most useful of various types of toxicity tests. This was because they were judged the most practical means for determining relative toxicities of various chemicals, relative sensitivities of different species, and effects of water quality on the toxicity of chemicals. However, chronic testing methodology has developed considerably since the time of that workshop.

\section{Design of Test Enclosure}

Most nonbacterial toxicity tests entail enclosure of test organisms in some variation of a static laboratory aquarium of relatively small, manageable size. When the test organisms are macroscopic in size, static enclosures generally hold just one or a few individuals. The static enclosure has the distinct advantage of experimental control and reproducibility. Extraneous variables that might affect test results are minimized and responses are relatively easy to measure. On the other hand, it has the disadvantage of presenting the test organisms with a very unnatural habitat. Their responses to stress in such a setting may be different than if they were in their natural environment, surrounded by other species with which they interact.

Various alternatives to static enclosures have been used with increasing frequency in recent years, especially for multispecies tests and for tests where the principal endpoint is something other than acute lethality. Although the static enclosure approach remains the most popular, other methods have been encouraged by improvements in toxicity-test methodology, including the development of complex design features and more sensitive measurement techniques. The selection of test-enclosure type depends largely on the test species used and the response endpoints monitored. Some species selections, such as bacteria, leave no choices of test enclosures.

\section{Multispecies Tests}

It is not necessary that a toxicity test be limited to a single species. Multispecies testing has been used with increasing frequency in recent years (Hansen and Tagatz, 1980; Kaushik and others, 1985; Phipps and Holcombe, 1985). Their advantages have been pointed out by Maciorowski and clarke (1980), Suter (1983), Cairns (1983, 1984, 1985), and Kimball and Levin (1985). 
The most frequent argument is that relative to a single-species test, the multispecies view offers the reseacher a more complete and realistic picture of probable toxicant effects on the entire community. Although there may be some loss in control of untested variables and standardization of procedures, it is argued that this is compensated by improved realism, completeness, and even sensitivity (Suter, 1983; Kimball and Levin, 1985). There is also an economical argument in support of multispecies testing. Costs per experiment are likely to be higher than single-species tests, but because the amount and quality of information is enhanced, the cost/benefit ratio can be reduced (Suter, 1983; Perez and Morrison, 1985).

It is important at this point to clarify the meaning of "multispecies testing." Two entirely different approaches may be signified by this term. One is a "microcosm" approach, in which a number of different species are exposed simultaneously to the same environmental stress. Under these conditions, the test "species" is actually a community of species that can interact with each other. Such tests are conducted with the hope that they mimic the natural environment. Rather than showing how the survival or metabolic activities of only one species are affected, these tests are expected to indicate how the toxicant will affect community characteristics such as succession, diversity, predator-prey relations, or dominant taxa. The "multispecies" approach may also refer to a "battery of tests" in which the toxicity problem is examined by conducting a number of separate single-species tests. A different species is employed in each test, and collectively they represent distinct trophic levels and/or they are sensitive to different types of toxicants. For example, a cladoceran species and a fish species might be used in a battery. In addition to representing different trophic levels, the cladoceran is likely to be more sensitive to metals, whereas the fish is more sensitive to organic compounds. The tests may be conducted simultaneously or sequentially (Cairns, 1983).

\section{Microcosm Approach}

Considerable success has been reported by authors using laboratory microcosms. Portier (1985) cited evidence from microbial studies to support use of benchtop microcosms as a toxicity-testing tool. Correlation coefficients generally greater than 0.9 were reported between lab and field measurements of a number of microbial population parameters and metabolic activities. Harrass and Taub (1985) described a standardized aquatic microcosm, designed to be an especially replicable system. The experimental systems were treated with copper, and responses compared to untreated microcosms and to reported results from field studies. Responses of the microcosms, with respect to algal/grazer interactions, species shifts in algal communities, and recovery of the systems when the toxicant treatment was terminated, were similar to those that generally are observed in natural systems. Levy and others (1985) compared the pelagic epilimnion of a California reservoir with three microcosms containing water from the same reservoir. No toxicants were added but the effects of water agitation were examined. For 6 weeks, the phytoplankton and zooplankton communities of two of the microcosms were virtually indistinguishable from those of the natural system. 
Microcosms designed as "in-situ" test enclosures have been used to mimic the natural environment as closely as possible. By suspending translucent enclosures on a vertical line, Marshall and Mellinger (1980) tested the effects of depth on responses of plankton to cadmium addition in Lake Michigan. Depth was indeed found to have an effect. The "limnocorral," a large in-situ enclosure placed in lakes to represent the natural pelagic community, was used by Kaushik and others (1985) and Herman and others (1986) to examine the effects of pesticides on plankton. The limnocorral technique was described as "an important tool for assessment of direct and indirect impacts" of toxicants (Kaushik and others, 1985).

Some general disadvantages of microcosm-type multispecies procedures were discussed by Mount (1985) and Slooff (1985). Costs and practical restrictions do not allow multispecies experiments to be fully representative of their simulated natural environments. The resulting generality in test design reduces sensitivity and predictability. Analysis of data from studies where both single-species and multispecies tests have been done show little difference in the results or conclusions of the different approaches. This led Slooff (1985) to the conclusion that "as long as there is no solid evidence that predictions made from single species tests are unreliable, there are no imperative reasons to propose expensive and time-consuming multispecies tests as additional or alternative research tools." Mount (1985) pointed out that if the primary purpose of the toxicological work is to examine the effects on a valuable resource species (for example, a sport fishery), singlespecies tests are certainly more suitable. He also suggested that the claims of improved realism and sensitivity may be misleading: "...community sensitivity is only an expression of individual species sensitivity...that there are interactions between species in multispecies tests is not a measure of their validity or informative value. In fact, the reverse could well be true!"

Numerous specific microcosm applications have demonstrated weaknesses in the microcosm approach. A three-phase (gaseous-sediment-aqueous) microcosm was used by Adams and others (1985) to simulate Lake Powell, Utah/Arizona and to study effects of and fate of benz(a)anthracene (BA). Results in the microcosm were representative of simultaneous field measurements, but differences in physical conditions caused significant differences in BA behavior. For example, reduced light levels substantially diminished the rate of photooxidation. Open microcosms were used by Selby and others (1985) to assess cadmium effects on a stream community. Because of the possibility of community changes unrelated to the toxicant, the method was not recommended for use as a screening tool. Woltering (1983) found that responses to toxicants in laboratory ecosystem studies were highly dependent on ecological factors such as predator-prey fluctuations, competition, energy input, and habitat availability. Predation can be an especially important controlling factor, and must be at least partially restricted in most microcosm studies (Harrass and Taub, 1985). Aging (nutrient depletion) of the microcosm can also influence toxicant effects on test organisms (Kindig and others, 1983). 
At the 1977 workshop on estimating the hazard of chemicals to aquatic life, where attendees evaluated various toxicity-test techniques (Macek and others, 1978), the microcosm approach was rated rather low in overall utility. It was considered inferior to most other techniques in ecological significance, scientific and legal defensibility, and simplicity and cost. Two of the participants in that workshop (Brungs and Mount, 1978) pointed out that the microcosm idea was basically sound, but that its implementation was still problematic because of difficulties in replicating the natural system.

Because of the increased complexity of microcosm-test procedures, it would be difficult to use them successfully on a routine basis in a largescale assessment program. However, they may be useful in small-scale assessments, such as in studies of selected stream reaches. In such cases, they would probably be used at sites where special toxicant problems may occur, as indicated by initial single-species tests, and chemical analyses.

\section{Battery Approach}

The precision and accuracy of any scientific study generally are improved both by replication of a single type of experiment and by sequential attack on the question using a variety of experiments. Given the uncertainties surrounding the assessment of biological responses to constituents in the aquatic environment, replication and sequential testing merit special consideration for toxicity testing. Interpretation of toxicity-test results involves comparisons between toxicant concentrations that elicit biological responses and actual toxicant concentrations in the natural environment. If a battery approach is used, there is a presumed improvement in the reliability of this comparison because it is based on a more diverse data base than it would be if only one test were used. The data base will be especially diversified if the selected test organisms represent different trophic levels (Maciorowski and Clark, 1980).

Several researchers have recently reported good results in applications of the battery approach. Dutka and Kwan (1982) found that four bacterial screening procedures they tested were each characterized by particular sensitivity patterns and could not be readily correlated with each other. If only one procedure were utilized, it could give misleading information. Further evidence that independent toxicity tests may give misleading results when interpreted alone was provided by data from Lake Ontario (Dutka and others, 1986). Plotkin and Ram (1984) tested the effects of sanitary landfill leachate on fish, daphnids, algae, and bacteria. The responses were very different among the different organisms, and not reliably predictable on the basis of measured concentrations of toxicants in the leachate. They concluded that toxicity assessments should be based on multiple tests with organisms from different trophic levels. Three test species--bacteria, oyster embryos, and amphipods--tested by Williams and others (1986) showed considerable variation in sensitivity to toxic sediments. The authors emphasized that a diversity of toxicity-testing procedures was important for evaluating sediment toxicity. 
Diversification of toxicity tests by using the battery approach may improve the reliability of statistical treatment by providing a broader data base. Multiple trophic levels may be tested, providing a more complete characterization of the community. The different strengths of a diverse array of tests may be used in complementary fashion.

Although the benefits of diversification are recognized, there are also disadvantages. The sensitivities of different test species vary considerably but, as shown in figure 2, they may all be insufficient to permit positive detections of contaminant concentrations commonly found in natural waters. Hence, consistent negative results from all tests of a battery do not necessarily lead to a firm conclusion that there is no toxicant problem. If, on the other hand, some of the tests in the battery produce positive results while others do not, the composite result may be ambiguous and interpretation may be especially difficult.

The previously discussed arguments against microcosm procedures may also apply to the battery approach. A multispecies approach, whether microcosm or battery, is more complex and costly than a single acute-lethality test. Is it simply a more costly means to arrive at the same answer? The cost problem is an especially important consideration for designing a toxicity-test approach for large-scale assessments.

A variation of the battery approach is a sequential screening procedure (Slooff, 1985) (fig. 3). A rapid test, such as a bacterial luminescence test, is used as an initial screening tool. If ambient substances produce stress responses in the initial screening test, a second test at a higher level of biological organization is performed. This process may proceed through several levels of biological organization to assess toxicity effects. Cairns, who had earlier joined with others in advocating the sequential test approach (Cairns and others, 1978), later argued that sequential testing, if done at all, should not proceed from lower to higher levels of biological organization (Cairns, 1983). He pointed out a "lack of substantive evidence that one can accurately predict the response at higher levels of biological organization from the single-species tests."

\section{Sediment Toxicity Tests}

Conventional toxicity tests involve assessment of the effects of toxicants dissolved or suspended in water. However, large numbers of aquatic organisms, including many of the test species listed in table 3, reside in or on the bottom sediments. Others are exposed directly to sedimentary materials because they are benthic or deposit feeders. Furthermore, sediments are an important repository for many contaminants that may be released to overlying water. These factors support the argument that toxicity assessments of aquatic systems should include exposure of test organisms to contaminants contained in the sediments. This is the rationale leading to relatively recent development and application of sediment toxicity tests, mostly in the marine environment (Tsai and others, 1979 Swartz and others, 1980; Chapman and Fink, 1984; Tietjen and Lee, 1984; Long and Chapman, 1985; Swartz and others, 


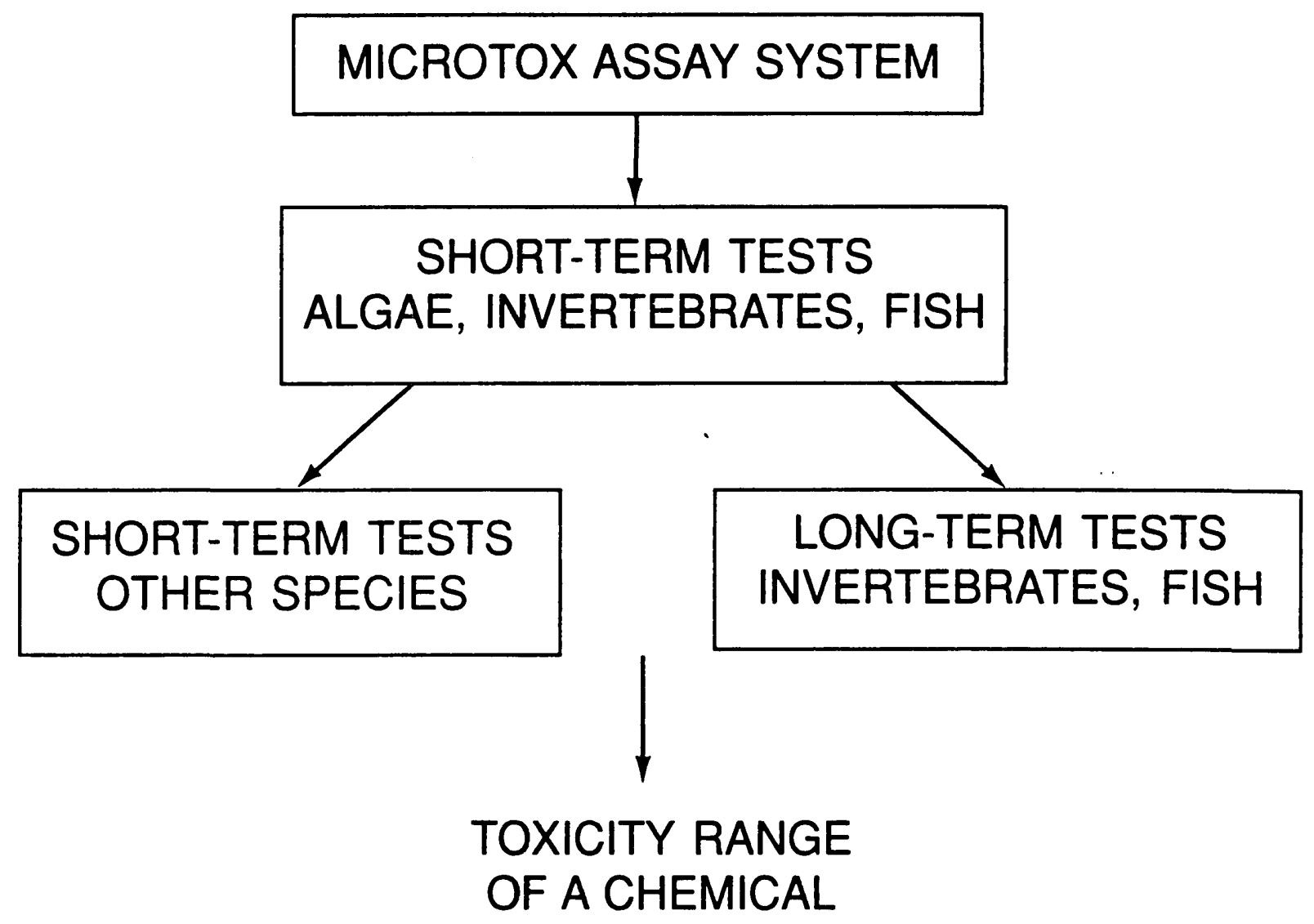

Figure 3. General scheme for sequential toxicity screening. 
1985; Mearns and others, 1986). Freshwater studies include those of Prater and Anderson (1977), Laskowski-Hoke and Prater (1981), Cairns and others (1984), Malueg and others, (1984a, b), Nebeker and others (1984), and Schuytema and others (1984).

Although sediment toxicity tests involve investigation of contaminants associated with the sediments, the exposure route is not necessarily through direct contact between organism and sediments. Any one of three different exposure routes are possible in the experimental design (Chapman, 1987):

1. Exposure to whole, intact sediments. This is generally the preferred exposure route, especially if the test species inhabits the sediments. The test enclosure contains contaminated sediments and water. The test species may be either benthic or pelagic (it may inhabit either sediments or water). Exposure may be through direct contact with sediments, ingestion of sedimentary materials, or contact with overlying water that carries desorbed or resuspended contaminants.

2. Exposure to a sediment elutriate (suspended or liquid phase). The test enclosure contains water that has previously contacted the contaminated sediments (as in a sediment-water slurry) for a specified time, then is filtered or centrifuged. Because of desorption or resuspension, water contains contaminants previously associated with sediments. The sediments themselves are not added to the test enclosure. This may be the method of choice if it is not practical to add sediments to the test system, or if the toxicological response involves aqueous contact (e.g. respiration; Chapman and Brinkhurst, 1984).

3. Exposure to a sediment extract. The test enclosure contains water to which sediment extract is added. The extract is an organic carrier solvent containing some of the contaminant that has transferred to it during an extraction procedure similar to those used for chemical analyses. Thus, the water/extract mixture contains contaminants previously associated with sediments. The sediments themselves are not added to the test enclosure. Again, this method may be appropriate if it is not practical to add sediments to the test system. It is applicable only for readily extractable nonionic organic contaminants (Chapman, 1987).

Comparisons of the elutriate and whole sediment exposure routes by Chapman and Fink (1984) showed some discrepancies in results. Toxicity responses in some cases were caused only by elutriate exposure and, in other cases, only by whole sediment exposure. Ideally, whole sediment exposure should be used in combination with either a sediment elutriate or sediment extract exposure to obtain more complete toxicity information.

Sediment toxicity-test procedures can be used for acute or chronic testing with any of the common test species, whether benthic or pelagic (Nebeker and others, 1984). Swartz and others (1985) monitored mortality and sublethal responses of amphipods exposed directly to sediments in static test beakers. Control survival was 95 percent and the organisms were quite 
sensitive to contaminants amended to the sediments. An example of the elutriate exposure method is the three-chamber-recirculation apparatus used by LeBlanc and Suprenant (1985) to test the effects of contaminated sediments on fathead minnows, daphnids, and midges. Responses of test organisms were closely correlated with the degree of chemical contamination of sediments.

Some verification studies of sediment tests have produced favorable results. Field validation by Swartz and others (1980) showed good correlations between sediment toxicity, as determined by amphipod responses, and 18 biological and geochemical variables on a pollution gradient on the Palos Verdes Shelf (California). Mearns and others (1986) conducted an interlaboratory comparison of an amphipod sediment toxicity test and obtained results that led them to recommend wider use of the test. Control survival was greater than 90 percent in five laboratories, and the laboratories were in close agreement on toxicity ranking and mean responses. Acute toxicity of sediment extracts as determined by bacterial bioluminescence (Schiewe and others, 1985) correlated with total concentrations of aromatic hydrocarbons, chlorinated hydrocarbons, and naphthalenes in the sediments.

The disadvantages of sediment toxicity testing should also be considered prior to incorporation in a long-term study plan. First, the introduction of sediments (or their elutriates or extracts) into the test system complicates the chemistry of the system and increases the likelihood of secondary variable effects. Second, although a more complex system may be more realistic, it also makes interpretation of test results more difficult. Third, the sensitivity of tests involving exposure to whole, intact sediments may be inferior to that of conventional tests because of the likelihood that the contaminant must move through the aqueous or suspended phase before affecting the test organism. Most quality assurance work with sediment techniques indicates good sensitivity, but it has also been noted that sediments tend to ameliorate toxicity of contaminants in the system (Chapman and others, 1982b; Graney and others, 1984). Fourth, relatively little previous work with sediment toxicity tests has been done, especially for freshwater systems. Therefore, the documentation of methods and availability of comparative data are limited. Finally, work with sediment increases the complexity of collecting samples for testing, and performing the actual tests.

The importance of sediments, both as a habitat for biological species and as a reservoir for many xenobiotic substances, suggests that sediment tests should not be overlooked in designing a toxicity-testing study. The most productive approach for most studies, provided adequate funding and personnel, is to implement a suitable combination of sediment and water tests supplemented with chemical analysis of the same sediment and water media.

\section{Biochemical Tests}

The toxicity of heavy metals and organic compounds to aquatic biota is very commonly attributable to direct or indirect effects of the toxicant on enzyme activity, biochemical functions, or membrane integrity (Neff, 1985). Therefore, it is reasonable to expect that one of the most sensitive indices of contaminant stress would be a change in enzyme activity, enzyme synthesis, or biochemical composition. Toxicity-test methods that utilize this approach 
have been developing rapidly in recent years. Most of the research has been done with fish.

It is logical to look at the effects of toxins on biochemical processes as a first step in toxicity testing. Biological responses to stress may be thought of as a series, propagating through increasingly complex levels of organization (Jenkins and Sanders, 1986). Biochemical changes are very early in the series; for practical purposes, they are initial responses. Furthermore, they are common to many different kinds of organisms. The biochemical changes may elicit subsequent responses at the cellular, organ, organism, population, and finally community levels. But as one proceeds along this scale of propagation, the variability of response increases because of increasing secondary effects due to individual tolerances and environmental factors. Thus, both the sensitivity and the reproducibility of biochemicalresponse measurements are likely to be greater than those of other types of toxicity testing.

Biochemical changes tend to be rapid and very responsive to causative factors in part because they are initial responses to stress. As an example, a study by Kurelec and others (1977) showed that mixed-function oxygenase activities in Blennideae $\mathrm{fish}$ in the Adriatic Sea increased by nearly an order of magnitude within a few days after an oil spill. This kind of quick and dramatic response is not uncommon.

There are many possible variations of the biochemical assay approach to toxicity testing. Generally, they involve exposure of the living organism or tissues of the organism to the contaminant and measurement of relatively short-term changes in enzyme activity, biochemical composition of blood and tissues, or production of detoxification proteins such as metallothioneins or mixed-function oxygenase systems. Biochemical techniques of monitoring responses may be applied either in a laboratory setting (test organisms in an enclosure) or a community survey (capture and analysis of native organisms).

Metallothioneins are proteins that have a high binding capacity for divalent metal cations. They have been identified in many species of $\mathrm{fish}$ and other animals, and they are thought to play an important role in detoxification of several metals, including silver, gold, cadmium, mercury, copper, and zinc (Neff, 1985). Exposure to elevated concentrations of such elements should stimulate production of metallothioneins (Roch and others, 1982; Thompson and others, 1982; Sanders and others, 1983; Sanders and Jenkins, 1984).

Mixed-function oxygenase (MFO) systems might be considered to be the counterpart to metallothioneins with respect to detoxification of organic contaminants. MFO systems include a group of enzymes that initiates metabolization of numerous lipophilic organic compounds, rendering them more water-soluble and therefore more available for excretion. They have also been identified in many fish species (Neff, 1985). Various studies have demonstrated increased MFO activity as a result of exposure to organics in the environment (Lech and others, 1982; Payne, 1976; Stegeman, 1978; Foureman and others, 1983). Ironically, the fish does not necessarily benefit from this increased MFO activity. Instead, there may actually be an increase in 
toxicity, owing to the production of intermediates that are carcinogenic (Hinton and others, 1981; Tan and others, 1981).

Enzymes may be affected directly or indirectly by toxicants, usually resulting in an increase in enzyme activity. Increased activity in glutamateoxaloacetate transaminase and glutamate-pyruvate transaminase, two indicators of liver pathology, may be induced by elevated concentrations of carbon tetrachloride (Casillas and others, 1983), or sewage discharges (Weisner and Hinterleitner, 1980). Some enzymes are affected specifically by certain pollutants. One of these is delta amino levulinic acid dehydratase (ALAD), which is contained in blood erythrocytes and is important in the formation of hemoglobin, cytochrome, and peroxidase. Its activity may be sharply inhibited by lead in the blood (Hodson and others, 1978). Concentrations as low as $10 \mathrm{\mu g} / \mathrm{L}$ can produce significant inhibition of erythrocyte ALAD in rainbow trout (Hodson and others, 1977). In other species, such as carp and white suckers, the ALAD activity was a less-sensitive indicator of lead contamination.

In addition to enzymes, the production and activity of various biochemical substances in the blood and tissues may be affected by exposure to toxicants. In fish blood, some of the substances most frequently affected by pollutants are cortisol, glucose, proteins, lactic acid, pyruvic acid, and cholesterol. In tissues, some of the most frequently affected substances are glycogen, proteins, lipids, collagen, glutathione, and ascorbic acid.

Biochemical responses to stress are common to all types of organisms and may thus be used as bioindicators of toxicity in a wide range of environmental situations. Responses vary according to the type and concentration of the causative agent (Jenkins and Sanders, 1986). These stress-response relations currently are not well understood but, as more information about them becomes available, the usefulness of biochemical testing to identify particular types of contaminant problems should improve.

Biochemical analysis offers considerable promise for application in large-scale studies. The number of possible methods is almost limitless, considering the number of toxic agents in the environment and the number of biochemical responses caused by those toxicants. In general, biochemical testing has the same advantages as bacterial tests and offers the additional advantage of greater sensitivity.

The primary disadvantages of the biochemical approach are (1) limited knowledge of the correlation between biochemical responses and deleterious effects on fish populations, and (2) biochemical variability caused by a great number of environmental variables other than toxicant concentrations (Neff, 1985). The latter problem is significant for biochemical techniques because there are so many factors that can have biochemical effects, and the resulting biochemical fluctuations can be dramatic. The stress of capture and handling can be an especially important controlling factor. As methodology development proceeds, some of these difficulties may be overcome and biochemical techniques will become increasingly useful. 


\section{Overview of Test Type Differences}

The differences among test types are reflected in their particular strengths and limitations. As a summary of the preceding discussion, table 20 lists major test types and some of the reasons why each type might be selected or deselected for water-quality assessment purposes.

Table 20.--Reasons for and against use of different toxicity-test procedures

1. Acute tests, single-species (static or flow-through).

- Good documentation of methods.

- Extensive data base of results from diverse systems.

o Endpoint (mortality) readily detected and monitored.

o Results reported in standardized, unambiguous LC50 format.

- Good control and replicability of test conditions.

2. Chronic tests, single-species.

- Relatively good documentation of methods.

- Large data base of results from diverse systems.

- Good control and replicability of test conditions.

- Sensitivity of sublethal responses greater than that of mortality (sometimes by orders of magnitude).
- Unnatural; single species responses in limited enclosure do not reflect species interactions in natural community.

o Variable sensitivity; species sensitive to some toxicants, insensitive to others.

- Relatively long culture times required; may cause mortality or other problems.

- Responses often subtle; may be difficult to detect or monitor.

o Format for reporting results not well standardized; can be ambiguous.

- Unnatural; single species responses in limited enclosure do not reflect species interactions in natural community.

- Variable sensitivity; species sensitive to some toxicants, insensitive to others.

- Long culture times required; may cause mortality or other problems. 
Table 20.--Reasons for and against use of different toxicity-test procedures--Continued

Arguments for:

Reasons against:

3. Laboratory microcosms, or multi-species tests.

- Relatively good documentation of methods.

- Ample data base of results from other studies.

o Good control and replicability of test conditions.

o Replication of natural community; responses incorporate species interactions.

\section{Bacterial tests.}

- Simplicity and rapidity; many replicates possible.

o May be conducted in local laboratories; eliminates need for shipping samples and delay between sampling and testing.

o Avoids many problems of lab enclosures and long culture times.

o Good representation of general toxicity because luminescence response is dependent on common biochemical pathways.

5. Biochemical or physiological tests.

- High sensitivity to most toxicants; biochemical or physiological changes one of first responses to environmental stresses.

o Simplicity; usually only involves collection of blood samples that may be stored or shipped with little risk of deterioration.

- Avoids problems of laboratory culture.

- Many replicate analyses possible.

- Responses readily detectable and may be reported in unambiguous manner.
- Complicated setup increases cost per test and decreases number of replicates possible.

- Multispecies situation increases complexity and likelihood of secondary variable effects and problems of laboratory culture.

- Responses often subtle; may be difficult to detect or monitor.

- Very poor sensitivity to most toxic agents.

o Poor reproducibility; sensitive to slight changes in test conditions or characteristics of bacterial populations. 
Table 20.--Reasons for and against use of different toxicity-test procedures--Continued

Arguments for:

Reasons against:

6. Community surveys in impacted and unimpacted areas.

o Study of natural system; avoids problems of artificial culture.

o Use of naturally occurring species.

- Simplicity; no laboratory setup required; low cost for supplies and equipment.

o Reflection of effects of long-term exposure rather than limited and arbitrary exposure time. o No control over environmental variables and associated secondary effects.

o Poor reproducibility over time and space because of changing conditions and variable samplecollection techniques.

- Time-consuming field work, species identification, and individual counting required; high labor cost.

7. Artificial substrates in natural environment.

- Study conducted in natural system; representation of natural conditions.

o Use of naturally occurring species.

o Simplicity; no laboratory setup required; low cost for supplies and equipment.
- No control over environmental true variables and associated secondary effects.

- Difficult to compare data over time and space because of changing conditions and different species.

- Time-consuming field work, species identification, and individual counting required; high labor cost.

- Species limited to those which can colonize artificial substrate.

- Risk of loss or destruction of test substrates.

8. Incubation of test organisms in cages in natural system.

o study conducted in natural system; true representation of natural conditions.

o Test species may be selected among most suitable bioindicator species.

o No laboratory setup required; relatively low cost for supplies and equipment.
- No control over environmental variables and associated secondary effects.

- Difficult to compare data over time and space because of changing conditions.

- Species generally limited to those that have relatively large size and limited mobility.

o Limited number of species tested; usually only one.

o Risk of loss or destruction of test enclosures. 


\section{FIELD AND INTERLABORATORY VERIFICATION OF TOXICITY TESTS}

Field verification of laboratory tests is one means of obtaining quality assurance information about toxicity-test procedures. In some cases, additional quality assurance has been achieved through interlaboratory comparisons.

A 1983 symposium (Boyle, 1985) was dedicated to validation of laboratory toxicity-testing methods, with emphasis on verification of microcosms and mathematical models by comparison to field data. Most of the authors reported favorably on their verification results (Adams and others, 1985; Giddings and Franco, 1985; Harrass and Taub, 1985; Levy and others, 1985; Portier, 1985).

Other verification results reported at the same 1983 symposium revealed some inconsistencies between laboratory and field data. Experiments by deNoyelles and Kettle (1985) to determine atrazine effects on phytoplankton indicated that short-term laboratory bioassays are reasonably effective at representing natural stress responses for about 24 hours, but later the responses become unnatural owing to conditions not representative of the natural environment. Effects of fluorine on various trophic levels were monitored in both laboratory static toxicity tests (Finger and others, 1985) and experimental ponds (Boyle and others, 1985). Algae and invertebrates were sensitive to fluorine in the laboratory enclosures, but, in the ponds, two fish species were found to be more sensitive than either the algae or the invertebrates.

Varying degrees of support for laboratory-testing methods have been expressed by other researchers who have compared laboratory and field data. Greene and others (1976) reported that replication of a natural lake community by the algal assay test was excellent, and they derived an equation for predicting chlorophyll-a concentrations in the lake based on assay results. Kallqvist (1984) also reported good results with algal assays, and suggested that the patterns of growth of experimental and control cultures can be used to classify natural waters into one of five categories of toxicant and nutritive conditions. Larsen and others (1986) compared three procedures-single-species tests, microcosm, and experimental pond--to examine effects of atrazine on eight species of algae. Good replication was reported; 50 percent inhibition of photosynthesis, respiration, and algal biomass occurred in all three systems at atrazine concentrations within the range of 100 to $150 \mu \mathrm{g} / \mathrm{L}$.

A study by Mount and others (1984) included diverse procedures whose results could be used to evaluate the validity of ambient toxicity testing. Effects of discharges from a municipal sewage treatment plant, a refinery, and a chemical company on the ottawa River, Ohio, were investigated. In addition to ambient toxicity tests of waters from various sites downstream from the discharge points, the study included effluent toxicity tests, dye studies to describe dilution characteristics of the effluents, and in-situ toxicity tests with fish in cages. It also included surveys of periphyton, phytoplankton, zooplankton, benthos, and fish. Positive toxicity-test results were obtained with some of the ambient samples collected from sites likely to be affected by the effluents. The authors reported that these results correlated reasonably well with aquatic community measurements, as determined by regression 
analyses. However, they also acknowledged that various complexities, such as year-to-year variations and toxicities upstream of effluent inputs, made interpretation difficult. They also pointed out the need for collection of extensive and diverse biological data. At least two test species from different trophic levels should be used, and biological surveys should include monitoring of many segments of the aquatic community.

A similar study by the same group (Mount and Norberg-King, 1985) of an Ohio stream included additional comparison of ambient toxicity-test results with community measurements. However, no verification of the test results was possible because no toxicity was shown by the tests. The stream receives discharge from a chemical resins plant, but even the undiluted effluent was not appreciably toxic to the test organisms.

Recent studies of sediments from embayments of Puget Sound, Washington (Long and Chapman, 1985; Chapman, 1986) included three phases: (1) sediment chemical analysis to determine concentrations of three metals, polychlorinated biphenyls, and polynuclear aromatic hydrocarbons, (2) sediment toxicity tests, using bulk sediments and an amphipod test species, and (3) surveys of the infaunal communities at the sample sites. This "sediment quality triad" approach showed good correlation among results from all three phases of the study. However, the correspondence was not nearly as consistent on a stationby-station basis. The authors recognized weaknesses in the data sets, and complexities such as contaminant interactions, that contributed to inconsistencies. The general implication was that if there is good correspondence among toxicity, chemistry, and community measurements, conclusions about the toxicity problem can be drawn, but if the correspondence does not occur it does not lead to converse conclusions. The deviation from "expected" results may be attributable to single or combined effects of innumerable environmental factors that are not accounted for in the triad analysis.

Various authors (Leeuwangh, 1978; Lee and Jones, 1983; Sadler, 1983; Kimball and Levin, 1985; Livingston and Meeter, 1985; Thorp and Gloss, 1986) have pointed out that reliability of laboratory tests is significantly influenced by differences between laboratory and natural systems in their physical, chemical, and ecological conditions. This might be termed a "secondary variable" effect, a biological response caused by unnatural conditions in the laboratory environment that is not related to additions of the tested contaminant. One of the most important secondary variables is $\mathrm{pH}$. Numerous studies have demonstrated effects of $\mathrm{pH}$ changes on toxicity of contaminants to test organism (Eloranta and Halttunen-Keyrilainen, 1984; Nasu and Kugimoto, 1981; Suloway and others, 1981; Giddings and others, 1983; Lee and Jones, 1983; Graney and others, 1984; Michnowicz and Weaks, 1984). In some cases, detrimental effects on the test organism caused by secondary variables may exceed toxic effects of the contaminant (Leeuwangh, 1978). Secondary variables may affect laboratory results in either direction. For example, low metal methylation rates may lead to underestimates of toxicity in laboratory tests (Benson and Summons, 1981), but the inability of mobile organisms to escape in a test enclosure may lead to overestimates of toxicity (Kimball and Levin, 1985). 
Table 21 summarizes reports of field verification of laboratory testing procedures. No clear consensus appears about whether laboratory tests are good indicators of contaminant effects in a natural system. However, there does seem to be good agreement between microcosm tests and natural systems monitoring.

Test types in table 21 are defined as follows:

STATIC: $\quad$ static, acute, single-species test in laboratory

FLOW-THROUGH: continuous-flow, acute, single-species test in laboratory

MICROCOSM: enclosed, simulated community, either in lab or field

NATURAL: natural aquatic system.

Data obtained by field monitoring, such as ecosystem surveys, measurements of community metabolism, etc.

Table 21.--Comparisons of different types of toxicity tests

[Symbols indicate whether study reported that there is good agreement between the two types of measurement ("+"), poor agreement ("o"), or variable agreement (both symbols shown)]

$\begin{array}{lllll} & & & \\ \text { STATIC AND } & \text { STATIC AND } & \text { STATIC AND } & \text { MICROCOSM } & \\ \text { FLOW-THROUGH } & \text { MICROCOSM } & \text { NATURAL } & \text { AND NATURAL } & \text { REFERENCE }\end{array}$

\begin{tabular}{|c|c|c|c|c|}
\hline $\begin{array}{l}0 \\
0\end{array}$ & $\begin{array}{l}+ \\
+ \\
+ \\
+\end{array}$ & $\begin{array}{ll}+ & \\
& \\
& \\
& 0 \\
+ & \\
& 0 \\
& \\
+ & \\
+ & \\
+ & 0 \\
+ & \\
+ & \\
+ & 0 \\
+ & 0\end{array}$ & $\begin{array}{l}+ \\
+ \\
+ \\
+ \\
+\end{array}$ & $\begin{array}{l}\text { Adams and others, } 1983 \\
\text { Adams and others, } 1985 \\
\text { Cherry and others, } 1980 \\
\text { Biesinger and others, } 1982 \\
\text { Thorp and Gloss, } 1986 \\
\text { Kettle and others, } 1980 \\
\text { Marshall, 1978 } \\
\text { Hansen and Garton, } 1982 \\
\text { Kimball and Levin, } 1985 \\
\text { Davies and Woodling, } 1980 \\
\text { Portier, } 1985 \\
\text { Giddings and Franco, } 1985 \\
\text { Greene and others, } 1976 \\
\text { Harass and Taub, 1985 } \\
\text { Kay and others, 1984 } \\
\text { Larsen and others, } 1986 \\
\text { Levy and others, } 1985 \\
\text { Norberg-King and Mount, } 1986 \\
\text { Mount and others, } 1984 \\
\text { Maciorowski and Clarke, } 1980 \\
\text { Sadler, } 1983 \\
\text { Blanck, } 1985\end{array}$ \\
\hline
\end{tabular}


Interlaboratory or "round-robin" tests have been conducted on several occasions to evaluate the reliability and precision of particular toxicitytest procedures. Favorable results of such a test were reported by Davis and Hoos (1975), who compared data from seven laboratories on determination of pentachlorophenate (PCP) toxicity to salmonid fishes. The range of 96-hour LC50 values reported for rainbow trout was 48 to $100 \mu \mathrm{g} / \mathrm{L}$, calculated by the log-probit estimate, and 47 to $106 \mu \mathrm{g} / \mathrm{L}$, calculated by nomographic analysis. The results were considered by the authors to show good consistency or, where disparities occurred, they could be explained by variations in physical or chemical conditions of the test. An interlaboratory comparison of determinations of silver and endosulfan toxicity to a polychaete worm, was conducted by Pesch and Hoffman (1983). Mean 28-day LC50 values reported were $165 \pm 52 \mu \mathrm{g} / \mathrm{L}$ for silver and $106 \pm 24 \mu \mathrm{g} / \mathrm{L}$ for endosulfan. These results were considered to demonstrate low variability among laboratories. A sediment toxicity test was evaluated by Mearns and others (1986), based on participation by five laboratories. The laboratories all reported better than 90-percent survival in control sediments. There was also at least 80 -percent agreement among the laboratories on the rank order of toxicity for three endpoints (survival, emergence, and reburial), and on the mean survival in the test sediments. Because of the narrow range of toxicity of the tested samples, the interlaboratory results did not show close agreement as to whether or not the sediments should be classified as toxic or nontoxic.

Somewhat less optimistic results of interlaboratory comparisons were reported by Nebeker (1982). Six laboratories participated in a round-robin experiment, based on Daphnia magna renewal life-cycle test results for silver and endosulfan toxicity. Four of the laboratories reported 48-hour EC50 values for silver within a range of 0.6 to $2.9 \mu \mathrm{g} / \mathrm{L}$, but the other two laboratories reported much higher values $(8.4$ to $55 \mu \mathrm{g} / \mathrm{L}$ ). The explanation given by the author for this discrepancy was that the two laboratories reporting the higher EC50 results used harder water in their experiments. The range of reported EC5.5 values for endosulfan was 158 to $720 \mu \mathrm{g} / \mathrm{L}$. A number of difficulties interfered with consistent results in this test, and the author concluded that "the Daphnia magna renewal life-cycle test was not validated as a routine, easily conducted test method."

A protocol for interlaboratory testing of a microcosm toxicity-test procedure was described by Taub (1985). Precaution in standardizing variables that might cause inconsistencies among different laboratories was emphasized. Preliminary analysis was done by comparing replicate control groups in a single laboratory. As stated by the author, "the ability to obtain repeatable results within a single laboratory is a necessary prerequisite to testing for reproducible results in different laboratories." These data could be used not only to evaluate the precision of replicate experiments but also to determine if the biological activity in the microcosms is sufficient to assess toxicant stresses. The analysis indicated both good replication and adequate biological activity.

In general, interlaboratory comparisons have indicated that toxicity tests can produce better precision than might be expected, given the extreme natural variability that is characteristic of nearly all biological systems. However, reports of good precision do not necessarily imply high accuracy. 
For example, if a toxicant is present at concentrations below the sensitivity of the test organisms, the concurrence of all participating laboratories in a negative result for this toxicant would simply emphasize the detection limitations of the test. Interlaboratory comparison data cannot be used to evaluate sensitivity, representativeness, or relevance of the test method (items 1, 2, and 6 of table 2).

\section{ALTERNATIVES TO LABORATORY TOXICITY TESTING}

Toxicity tests conducted in static, flow-through, or microcosm systems represent just some of various types of biological study that could fill the need for biological data to assess water quality. These types of tests most directly address the question of effects of contaminants. However, certain alternative approaches may be implemented to provide somewhat different kinds of information about toxicity.

One alternative is to omit test enclosures altogether and conduct ecological surveys in the study basin. The sites for such surveys may be selected to represent a range of contaminant conditions in the basin. Chemical data may be used to make appropriate site selections. The survey data can provide information about community structure (species present and relative abundance of each), diversity (numbers of species relative to numbers of individuals), and biomass (total abundance of biota, regardless of taxa). This information provides a useful complement to chemical data collected at the same sites and times (Lafont, 1984; Long and Chapman, 1985).

Ecological surveys avoid some of the problems of prolonged incubation of enclosure organisms in artificial enclosures. They are not dependent on representation of an entire system by a limited number of species, and they are not subject to inaccuracy due to unnatural conditions in a controlled environment. More analytical work (for species identification and organism counts) is required but standard methods are generally available. Costs for this analytical work may be offset by savings in labor and equipment costs.

The principal disadvantage of ecological survey analysis is that the lack of control on environmental variables limits the ability of the researcher to infer cause-effect relations from the results. Even if trends are found (either temporal or spatial), they are not sufficient in themselves to show cause and effect. However, they do provide clues that may be used to identify areas that merit further toxicity testing and other biological investigation. Conversely, if no trend is found, the study makes a significant statement that would be totally lacking if only the chemical data were available.

A second alternative is to install artificial substrates in the natural environment. As in the ecological surveys, site locations are selected to represent a range of contaminant conditions. The colonization of the artificial substrates by natural biota is observed and measured after being left undisturbed in the system for a specified time period. Colonization rates and species composition of the established community may reflect contaminant effects. Several possible variations of this general procedure are possible, including the incubation of natural substrates from the stream 
system, or the measurement of loss of organisms from a substrate (such as loss due to drift of attached benthos). Like the ecological survey approach, this procedure has the advantages and disadvantages of being conducted in the natural environment. However, it is somewhat less natural and more controlled than the ecological survey because of the use of standardized colonization surfaces and a limited and rather arbitrary colonization time.

A third alternative is to introduce test organisms in the natural environment in enclosures, such as cages, that prevent their escape but allow exposure to all elements of the environment just as if they were free-living. After a specified incubation period, mortality and/or sublethal changes may be determined and compared with control organisms incubated in unaffected sites. This procedure is similar to a standard toxicity test because it uses test organisms selected primarily for their sensitivity and practicality for study, and it entails enclosure of the organisms for a limited incubation time. On the other hand, it is similar to ecological surveys or artificial substrate measurements because the organisms are exposed to natural conditions.

Toxicity-test procedures that use relatively large test organisms such as molluscs may be supplemented by tissue analysis to determine bioaccumulation rates. If contaminants are accumulated over time in the biological tissue, the organisms function as integrators of time-variable contaminant inputs and thus allow detection of substances that might be missed by analysis of constituents in water. However, bioaccumulation rates are highly dependent on the constituents as well as the biological species involved. They are also susceptible to changes in environmental conditions such as $\mathrm{pH}$, temperature, sediment characteristics, and organic carbon concentrations.

\section{SUMMARY}

Contaminants in the aquatic environment are of concern for biological reasons. They are potentially harmful to native aquatic organisms and to nonaquatic organisms, including humans, that use the water resource in some way. Organisms that are not directly affected by the contaminants may suffer indirectly through food-web transfers. Therefore, biological analyses add breadth and relevance to a water-quality monitoring program. As one of several types of biological analysis, toxicity testing produces information about direct impacts of contaminants on aquatic biota. Combined with chemical analyses, toxicity-testing procedures may provide an opportunity to correlate biological variables with contaminant concentrations and chemistry. However, there are important limitations to application of toxicity testing procedures to a large-scale assessment program. These include sensitivity limitations, difficulties in representing the natural environment, response variability among test organisms, and secondary variable effects.

To further summarize the information in this report, I refer back to the five questions raised in the Introduction. The questions are repeated below, along with my brief answers to them, based on the foregoing review. 
1. What are the characteristics and applications of different types of toxicity tests?

A wide variety of test types are documented by published reports. Procedures may be distinguished primarily on the basis of four criteria: (1) test species, (2) endpoints, (3) test enclosures, and (4) test substance or toxicant. Ambient tests may be done with water, sediments, or sediment extracts. The test organisms used may be limited to a single known species, or may include mixed species. Applications vary according to test type and study objectives. Applications such as the use of test results as a preliminary survey for planning further toxicological research or as a verification of other types of water quality monitoring involve relatively little risk of error. More risky applications are those that require extrapolation of test results to more complex systems.

2. What are the advantages and disadvantages of different types of test procedures, particularly with reference to application in national or regional water-quality assessments?

Acute tests, including bacterial tests, are straight-forward and rapid, but they often have poor sensitivity and are not representative of natural situations. Chronic tests commonly offer better sensitivity and are more realistic, but endpoints are usually more subtle and difficult to monitor. Chronic responses are highly susceptible to changes in environmental conditions. Multispecies tests, such as large microcosm experiments, might extend the general applicability and sensitivity range beyond those of a single-species test, but their use in large-scale studies is limited by their design complexities.

Compared with laboratory toxicity tests, field-oriented procedures more closely represent natural situations and they are not as subject to error due to artificial experimental conditions or species selection. There are other important sources of error, however, including natural biological variability, sampling inconsistencies, and lack of control over environmental conditions. Where possible, it is advantageous to employ both laboratory and field procedures, in addition to chemical analyses, to provide a diverse data base for thorough quality assessment.

3. Do the results of toxicity tests accurately reflect environmental conditions and the probable effects of contaminants on biota in natural systems?

It is rare that a microcosm situation, as used in most toxicity tests, can truly mimic the natural system it is intended to represent. Although many documented toxicity tests may be considered to be reliable measures of toxic effects under specified conditions, they cannot replicate the complexity or variability of the natural system. A positive result suggests the potential for a toxicant problem in the natural system, but does very little to predict the nature of the probable response. A negative result does not prove the absence of a problem or potential problem in the natural system. 
Notwithstanding the difficulty in representing natural situations and stress responses, toxicity tests can be useful to indicate the occurrence of a condition that may be of concern, and to point out possible directions of further research. They may be especially applicable when used in conjunction with other water-quality and hydrologic monitoring data. Hence, failure to closely mimic natural stress responses is not necessarily critical. The need to accurately represent a natural system depends on the intended use of the test results.

4. Will different toxicity tests result in different conclusions about the conditions of an ecosystem and its toxicant problems?

Yes. Because of widely varying sensitivities among different species and among different test conditions, two different types of tests are unlikely to give similar results. This is the principal argument for implementation of a battery of tests in a large-scale assessment program. Procedures included in the battery may be selected so that the test species represent different trophic levels, and the tests complement each other with respect to sensitivity to different toxic agents. More extensive and diverse data would be produced, and false negative results would be less likely (assuming that a positive response on just one test in the battery would constitute an overall positive result). However, there would be substantially greater labor and monetary expenditure than would be required for a single test.

5. Is there a particular type of test, with respect to selection of test species, test substance (ambient or artificial), and test medium (water or sediment), that is especially suitable for water-quality assessment and that can be applied in standardized format over a broad range of aquatic systems and environmental conditions?

No. The prospects for a single, universally applicable test, using live organisms in laboratory enclosures, are negligible due to the variety of toxicant situations and the diversity of biological communities and environmental conditions among different study sites.

Many criteria are important for selection of an appropriate toxicity test. Sensitivity and capability to represent species responses in the natural environment are the most critical. Other criteria that are especially important for selecting tests to use in large-scale studies are reproducibility, simplicity of procedures, availability of background information, documented methodology, and cost. Each test type has its advantages, but none meets all of the selection criteria adequately to be considered useful as a universal test.

The best prospects for future development of a universally applicable test are in the area of biochemical assays. There are many sensitive biochemical methods, most of which are simple and applicable with native organisms. Most important of their advantages is that the biochemical changes monitored are initial responses to environmental stimuli, and the responses are common to nearly all organisms. 


\section{REFERENCES CITED}

Abel, P.D., 1980, Toxicity of x-hexachlorocyclohexane (Lindane) to Gammarus pulex: mortality in relation to concentration and duration of exposure: Freshwater Biology, v. 10, p. 251-259.

Abel, P.D., and Garner, S.M., 1986, Comparisons of median survival lethal exposure times for Gammarus pulex exposed to cadmium, permethrin and cyanide: Water Research, v. 20, no. 5, p. 579-582.

Adams, N., Goulding, K.H., and Dobbs, A.J., 1985, Toxicity of eight watersoluble organic chemicals to Selenastrum capricornutum: a study of methods for calculating toxic values using different growth parameters: Archives of Environmental Contamination and Toxicology, v. 14, p. 333345 .

Adams, V.D., Werner, M.D., Parker, J.D., and Porcella, D.B., 1985, Use of a three-phase microcosm for analysis of contaminant stress on aquatic ecosystems, in Boyle, T.P., ed., Validation and predictability of laboratory methods for assessing the fate and effects of contaminants in aquatic ecosystems: Philadelphia, American Society for Testing and Materials, Special Technical Publication 865, p. 31-42.

Adams, W.J., and Heidolph, B.B., 1985, Short-cut chronic toxicity estimates using Daphnia magna, in Cardwell, R.D., Purdy, R., and Bahner, R. C., eds., Aquatic toxicology and hazard assessment: Philadelphia, Seventh Symposium, American Society for Testing and Materials, Special Technical Publication 854, p. 87-103.

Adams, W.J., Kimerle, R.A., Heidolph, B.B. and Michael, P.R., 1983, Field comparison of laboratory-derived acute and chronic toxicity data, in Bishop, W.E.., Cardwell, R.D., and Heidolph, B.B., eds., Aquatic toxicology and hazard assessment: Philadelphia, Sixth Symposium, American Society for Testing and Materials, Special Technical Publication 802 , p. 367-385.

Adelman, I.R., and Smith, L.L., Jr., 1976, Fathead minnows (Pimephales promelas) and goldfish (Carassins auratus) as standard fish in bioassays and their reaction to potential reference toxicants: Journal of the Fisheries Research Board of Canada, v. 33, no. 2, p. 209-214.

Adelman, I.R., Smith, L.L. Jr., and Siesennop, G.D., 1976, Effect of size or age of goldfish and fathead minnows on use of pentachlorophenol as a reference toxicant: Water Research, v. 10, p. 685-687.

Adema, D.M.M., 1978, Daphnia magna as a test animal in accute and chronic toxicity tests: Hydrobiologia, v. 59, no. 2, p. 125-134. 
Alexander, H.C., McCarty, W.M., and Bartlett, E.A., 1978, Toxicity of perchloroethylene, trichloroethylene, 1,1,1-trichloroethane, and methylene chloride to fathead minnows: Bulletin of Environmental Contamination and Toxicology, v. 20, p. 344-352.

Aly, O.A., Shehata, S.A. and Farag, Hoda, 1984, Uptake and accumulation of selected herbicides by the freshwater alga Scenedesmus: Archives of Environmental Contamination and Toxicology, v. 13, p. 701-705.

American Public Health Association, American Water Works Association, and Water Pollution Control Federation, 1985, Standard methods for the examination of water and wastewater (16th ed.): American Public Health Association, Washington, D.C., 1,268 p.

Anderson, R.L., 1980, Chironomidae toxicity tests---biological background and procedures, in Buikema, A.L., Jr. and Cairns, John, Jr., eds., Aquatic invertebrate bioassays: Philadelphia, American Society for Testing and Materials, Special Technical Publication 715, p. 70-80.

Arthur, J.W., 1980, Review of freshwater bioassay procedures for selected amphipods, in Buikema, A.L., Jr. and Cairns, John, Jr., eds., Aquatic invertebrate bioassays: Philadelphia, American Society for Testing and Materials, Special Technical Publication 715, p. 98-108.

Babich, H. and Stotzky, G., 1985, A microbial assay for determining the influence of physiochemical environmental factors on the toxicity of organics: phenol: Archives of Environmental Contamination and Toxicology, v. 14, p. 409-415.

Bailey, H.C., and Liu, D.H.W., 1980, Lumbriculus variegatus, a benthic oligochaete, as a bioassay organism, in Eaton, J.G., Parrish, P.R., and Hendricks, A.C., eds., Aquatic toxicology: Philadelphia, American Society for Testing and Materials, Special Technical Publication 707, p. 205-215.

Barera, Yvette, and Adams, W.J., 1983, Resolving some practical questions about Daphnia acute toxicity tests, in Bishop, W.E., Cardwell, R.D., and Heidolph, B.B., eds., Aquatic toxicology and hazard assessment: Philadelphia, Sixth Symposium, American Society for Testing and Materials, Special Technical Publication 802, p. 509-518.

Bartlett, Larry, Rabe, F.W., and Funk, W.H., 1974, Effects of copper, zinc, and cadmium, on Selenastrum capricornutum: Water Research, v. 8, p. 179185 .

Batac-Catalan, Z., and White, D. S., 1983, Effect of chromium on larval chironomidae as determined by the optical-fiber light-interruption biomonitoring system, in Bishop, W.E., Cardwell, R.D., and Heidolph, B.B., eds., Aquatic toxicology and hazard assessment: Philadelphia, Sixth Symposium, American Society for Testing and Materials, Special Technical Publication 802, p. 469-481. 
Beak, T.W., Griffing, T.C., and Appleby, A.G., 1973, Use of artificial substrate samplers to assess water pollution, in Cairns, John, Jr. and Dickson, K.L., eds., Biological methods for the assessment of water quality: Philadelphia, American Society for Testing and Materials, Special Technical Publication 528, p. 227-241.

Benfield, E.F., and Buikema, A.L., Jr., 1980, Synthesis of miscellaneous invertebrate toxicity tests, in Buikema, A.L., Jr., and Cairns, John, Jr., eds., Aquatic invertebrate bioassays: Philadelphia, American Society for Testing and Materials, Special Technical Publication 715, p. 174-187.

Benson, A.A., and Summons, R.E., 1981, Arsenic accumulations in Great Barrier Reef invertebrates: Science, v. 211, p. 482-483.

Berglind, Rune, and Dave, Goran, 1984, Acute toxicity of chromate, DDT, PCP, TPBS, and zinc to Daphnia magna cultured in hard and soft water: Bulletin of Environmental Contamination and Toxicology, v. 33, no. 1, p. 63-68.

Berkowitz, David, 1979, Potential uses of bacteria in toxicology: Veterinary and Human Toxicology, v. 21, no. 6, p. 422-426.

Besch, W.K., Kemball, A., Meyer-Waarden, K., and Scharf, B., 1977, A biological monitoring system employing rheotaxis of $\mathrm{fish}$, in Cairns, John, Jr., Dickson, K.L., and Westlake, G.F., eds., Biological monitoring of water and effluent quality: Philadelphia, American Society for Testing and Materials, Special Technical Publication 607, p. 56-74.

Biesinger, K.E., Anderson, L.E., and Eaton, J.G. 1982, Chronic effects of inorganic and organic mercury on Daphnia magna: toxicity, accumulation, and loss: Archives of Environmental Contamination and Toxicology, v. 11, p. 769-774.

Birge, W.J., Black, J.A., Hudson, J.E., and Bruser, D.M., 1979, Embryolarval toxicity tests with organic compounds, in Marking, L.L., and Kimerle, R.A., eds., Aquatic toxicology: Philadelphia, American Society for Testing and Materials, Special Technical Publication 667, p. 131-147.

Bishop, W.E., and Perry, R.L., 1981, Development and evaluation of a flowthrough growth inhibition test with duckweed (Lemna minor), in, Branson, D.R., and Dickson, K.L., eds., Aquatic toxicology and hazard assessment: Philadelphia, Fourth Conference, American Society for Testing and Materials, Special Technical Publication 737, p. 421-435.

Bitton, Gabriel, 1982, Bacterial and biochemical tests for assessing chemical toxicity in the aquatic environment: a review: Critical Reviews in Environmental Control, v. 13, no. 1, p. 51-67. 
Black, J.A., Roberts, R.F., Johnson, D.M., Minicucci, D.D., Mancy, K.H., and Allen, H.E., 1973, The significance of physicochemical variables in aquatic bioassays of heavy metals, in Glass, G.E., ed., Bioassay techniques and environmental chemistry: Ann Arbor, Michigan, Ann Arbor Science, p. 259-276.

Blanck, H., 1984, Species dependent variation among aquatic organisms in their sensitivity to chemicals: Ecological Bulletin, v. 36, p. 107-119.

Blanck, H., 1985, A simple, community level, ectoxicological test system using samples of periphyton: Hydrobiologia, v. 124, no. 3, p. 251-261.

Bobra, A.M., Shiu, W.Y., and Mackay, Donald, 1983, A predictive correlation for the acute toxicity of hydrocarbons and chlorinated hydrocarbons to the water flea (Daphnia magna): Chemosphere, v. 12, no. 9/10, p. 1,1211,129 .

Bone, Q. and Marshall, N.B., 1982, Biology of fishes: Glasgow, Blackie and Son, Ltd., $253 \mathrm{p}$.

Bowman, M.C., Oller, W.L., Cairns, T., Gosnell, A.B., and Oliver, K.H., 1981, Stressed bioassay systems for rapid screening of pesticide residues. Part I: evaluation of bioassay systems: Archives of Environmental Contamination and Toxicology, v. 10, no. 1, p. 9-24.

Bowmer, K.H., 1986, Rapid biological assay and limitations in macrophyte ecotoxicology: a review: Australian Journal of Marine and Freshwater Research, v. 37, p. 297-308.

Boyle, T.P., ed., 1985, Validation and predictability of laboratory methods for assessing the fate and effects of contaminants in aquatic systems: Philadelphia, American Society for Testing Materials, Special Technical Publication $865,233 \mathrm{p}$.

Boyle, T.P., Finger, S.F., Paulson, R.L., and Rabeni, C.F., 1985, Comparison of laboratory and field assessment of fluorene-part II: effects on the ecological structure and function of experimental pond ecosystems, in Boyle, T.P., ed., Validation and predictability of laboratory methods for assessing the fate and effects of contaminants in aquatic systems: Philadelphia, American Society for Testing Materials, Special Technical Publication 865, p. 134-151.

Brinkhurst, R.O. and Cook, D.G., 1974, Aquatic earthworms (Annelida: Oligochaeta), in Hart, C.W., Jr. and Fuller, S.L.H., eds., Pollution ecology of freshwater invertebrates: New York, Academic Press, p. 143156.

Brock, T.D., 1979, Biology of microorganisms (3rd ed.): Englewood Cliffs, New Jersey, Prentice-Hall, 802 p. 
Brown, V.M., 1973, Concepts and outlook in testing the toxicity of substances to fish, in Glass, G.E., ed., Bioassay techniques and environmental chemistry: Ann Arbor, Michigan, Ann Arbor Science Publishers, chap. 2, p. 73-95.

Brungs, W.A., 1973, Continuous flow boiassays with aquatic organisms: procedures and applications, in Cairns, John, Jr. and Dickson, K.L., eds., Biological methods for the assessment of water quality: Philadelphia, American Society for Testing and Materials, Special Technical Publication 528, p. 117-126.

Brungs, W.A., and D.I. Mount, 1978, Introduction to a discussion of the use of aquatic toxicity tests for evaluation of the effects of toxic substances, in Cairns, John, Jr., Dickson, K.L., and Maki, A.W., eds., Estimating the hazard of chemical substances to aquatic life: Philadelphia, American Society for Testing Materials, Special Technical Publication 657, p. 15-26.

Buikema, A.L., Jr., Geiger, J.G., and Lee, D.R., 1980, Daphnia toxicity tests, in Buikema, A.L., Jr., and Cairns, John, Jr., eds., Aquatic invertebrate bioassays: Philadelphia, American Society for Testing and Materials, Special Technical Publication 715, p. 48-69.

Bulich, A.A., 1979, Use of luminescent bacteria for determining toxicity in aquatic environments, in Marking, L.L., and Kimerle, R.A., eds., Aquatic toxicology: Philadelphia, American Society for Testing and Materials, Special Technical Publication 667, p. 98-106.

Bulich, A.A., Greene, M.W., and Isenberg, D.L., 1981, Reliability of the bacterial luminescence assay for determination of the toxicity of pure compounds and complex effluents, in Branson, D.R., and Dickson, K.L., eds., Aquatic toxicology and hazard assessment: Philadelphia, Fourth Conference, American Society for Testing and Materials, Special Technical Publication 737, p. 338-347.

Burton, G.A., Jr., and Lanza, G.R., 1985, Sediment microbial activity tests for the detection of toxicant impacts, in Cardwell, R.D., Purdy, R., and Bahner, R.C., eds., Aquatic toxicology and hazard assessment: Seventh Symposium, American Society for Testing and Materials, Special Technical Publication 854 , p. 214-228.

Cairns, John, Jr., 1983, The case for simultaneous toxicity testing at different levels of biological organization, in Bishop, W.E., Cardwell, R.D., and Heidolph, B.B., eds., Aquatic toxicology and hazard assessment: Philadelphia, Sixth Symposium, American Society for Testing and Materials, Special Technical Publication 802, p. 111-127.

Cairns, John, Jr., 1984, Multispecies toxicity testing: Environmental Toxicology and Chemistry, v. 3, no. 1, p. 1-3. 
Cairns, John, Jr., ed., 1985, Multi-species toxicity testing: New York, Pergamon Press, Society of Environmental Toxicology and Chemistry, Special Publication, 261 p.

Cairns, John, Jr., Dickson, K.L., and Maki, A.W., 1978, Summary and conclusions, in Cairns, John, Jr., Dickson, K.L., and Maki, A.W., eds., Estimating the hazard of chemical substances to aquatic life: Philadelphia, American Society for Testing and Materials, Special Technical Publication 657, p. 191-197.

Cairns, M.A., Nebeker, A.V., Gakstatter, J.H., and Griffis, W.L., 1984, Toxicity of copper-spiked sediments to freshwater invertebrates: Environmental Toxicology and Chemistry, v. 3, no. 3, p. 435-445. Canfield, D.E., Jr., Linda, S.B., and Hodgson, L.M., 1985, Chlorophyllbiomass-nutrient relationships for natural assemblages of Florida phytoplankton: Water Resources Bulletin, v. 21, no. 3, p. 381-391.

Casillas, Edmundo, Myers, Mark, and Ames, W.E., 1983, Relationship of serum chemistry values to liver and kidney histopathology in English sole (Parophrys vetulus) after acute exposure to carbon tetrachloride: Aquatic Toxicology, v. 3, no. 6, p. 1,393-1,397.

Chang, J.C., Taylor, P.B., and Leach, F.R., 1981, Use of the microtex assay system for environmental samples: Bulletin of Environmental Contamination and Toxicology, v. 26, no. 2, p. 150-156.

Chapman, Gary A., 1983, Do organisms in laboratory toxicity tests respond like organisms in nature?, in Bishop, W.E., Cardwell, R.D., and Heidolph, B.B., eds., Aquatic toxicology and hazard assessment: Philadelphia, Sixth Symposium, American Society for Testing and Materials, Special Technical Publication 802; p. 315-327.

Chapman, P.M., 1987, Marine sediment toxicity tests, in Lichtenberg, J.J., Winter, F.A., Weber, C.I., and Fradkin, L., eds., Proceedings of symposium on chemical and biological characterization of sludges, sediments, dredge spoils and drilling muds, May 20-22, 1986: Cincinnati American Society for Testing and Materials, Special Technical Publications 976, p. 391-402.

Chapman, P.M., 1986, Sediment bioassay tests provide toxicity data necessary for assessment and regulation, in Geen, G.H., and Woodward, K.L., Proceedings of the 11th Annual Aquatic Toxicity Workshop, November 13-15, 1984: Vancouver, BC, Canada, Technical Report of Fisheries and Agriculture Science, no. 1480, p. 178-197.

Chapman, P.M., and Brinkhurst, R.0., 1984, Lethal and sublethal tolerances of aquatic oligochaetes with reference to their use as a biotic index of pollution: Hydrobiologia, v. 115, p. 139-144. 
Chapman, P.M., Dexter, R.N., Kocan, R.M., and Long, E.R., 1985, An overview of biological effects testing in Puget Sound, Washington: methods, results, and implications, in Cardwell, R.D., Purdy, R., and Bahner, R.C., eds.: Aquatic toxicology and hazard assessment: Philadelphia, Seventh Symposium, American Society for Testing and Materials, Special Technical Publication 854, p. 344-363.

Chapman, P.M., Farrell, M.A., and Brinkhurst, R.O., 1982a, Effects of species interactions on the survival and respiration of Limnodrilus hoffmeisteri and Tubifex tubifex (Oligochaeta, Tubificidae) exposed to various pollutants and environmental factors: Water Research, v. 16, p. $1,405-1,408$.

Chapman, P.M., Farrell, M.A., and Brinkhurst, R.0., 1982b, Relative tolerances of selected aquatic oligochaetes to individual pollutants and environmental factors: Aquatic Toxicology, v. 2, p. 47-67.

Chapman, P.M., and Fink, Ronald, 1984, Effects of Puget Sound sediments and their elutriates on the life cycle of Capitella capitata: Bulletin of Environmental Contamination and Toxicology, v. 33, no. 4, p. 451-459.

Chapman, P.M., and Long, E.R., 1983, The use of bioassays as part of a comprehensive approach to marine pollution assessment: Marine Pollution Bulletin, v. 14, no. 3, p. 81-84. Chapman, P.M., and Mitchell, D.G., 1986, Acute tolerance tests with the oligochaetes Nais communis (Naididae) and Ilyodrilus frantzi (Tubificidae): Hydrobiologia, v. 137, p. 61-64.

Cherry, D.S., Rodgers, J.H., Jr., Graney, R.L., and Cairns, John, Jr., 1980, Dynamics and control of the Asiatic clam in the New River, Virginia: Blacksburg, Va., Virginia Polytechnic Institute and State University, Virginia Water Resources Research Center, Bulletin 123 (Project B-101VA), $72 \mathrm{p}$.

Chiou, C.T., 1985, Partition coefficients of organic compounds in lipid-water systems and correlations with fish bioconcentration factors: Environmental Science and Technology, v. 19, no. 1, p. 57-62.

Christensen, E.R., Scherfig, J., and Dixon, P.S., 1979, Effects of manganese, copper and lead on Selenastrum capricornutum and Chlorella stigmatophora: Water Research, v. 13, no. 1, p. 79-92.

Cleveland, Laverne, Mayer, F.L., Buckler, D.R., and Palawski, D.U., 1986, Toxicity of five alkyl-aryl phosphate ester chemicals to four species of freshwater fish: Environmental Toxicology and Chemistry, v. 5, no. 3, p. 273-282.

Coleman, R.N., Qureshi, A.A., 1985, Microtox and Spirillum voluntans tests for assessing toxicity of environmental samples: Bulletin of Environmental Contamination and Toxicology, v. 35, p.443-451 
Cowgill, U.M., Hopkins, D.L., Applegath, S.L., Takahashi, I.T., Brooks, S.D., and Milazzo, D.P., 1985, Brood size and neonate weight of Daphnia magna produced by nine diets, in Bahner, R.C., and Hansen, D.J., eds., Aquatic toxicology and hazard assessment: Philadelphia, Eighth Symposium, American Society for Testing and Materials, Special Technical Publication 891, p. 233-244.

Curtis, Carolanne, Lima, Ann, Lozano, S.J., and Veith, G.D., 1982, Evaluation of a bacterial bioluminescence bioassay as a method for predicting acute toxicity of organic chemicals to fish, in Pearson, J.G., Foster, R.B., and Bishop, W.E., eds., Aquatic toxicology and hazard assessment: Philadelphia, Fifth Conference, American Society for Testing and Materials, Special Technical Publication 766, p. 170-178.

Cushman, R.M., and McKamey, M.I., 1981, A Chironomus tentans bioassay for testing synthetic fuel products and effluents, with data on acridine and quinoline: Bulletin of Environmental Contamination and Toxicology, v. 26 , no. 5, p. 601-605.

Darville, R.G., and Wilhm, J.L., 1984, The effect of naphthalene on oxygen consumption and hemoglobin concentration in Chironomus attenuatus and on oxygen consumption and life cycle of Tanytarsus dissimilis:

Environmental Toxicology and Chemistry, v. 3, no. 1, p. 135-141.

Dauble, D.D., Daly, D.S., and Abernethy, C.S., 1985, Factors affecting growth and survival of the Asiatic clam, Corbicula sp., under controlled laboratory conditions, in Cardwell, R.D., Purdy, R., and Bahner, R.C., eds., Aquatic toxicology and hazard assessment: Philadelphia, Seventh Symposium, American Society for Testing and Materials, Special Technical Publication 854, p. 134-144.

Davies, P.A., and Woodling, J.D., 1980, Importance of laboratory-derived metal toxicity results in predicting in-stream response of resident salmonids, in Eaton, J.G., Parrish, P.R., and Hendricks, A.C., eds., Aquatic toxicology: Philadelphia, American Society for Testing and Materials, Special Technical Publication 707, p. 281-299.

Davis, J.C., and Hoos, R.A.W., 1975, Use of sodium pentachlorophenate and dehydroabietic acid as reference toxicants for salmonid bioassays: Journal of the Fisheries Research Board of Canada, v. 32, no. 3, p. 411416.

DeGraeve, G.M., Geiger, D.L., Meyer, J.S, and Bergman, H.L., 1980, Acute and embryo-larval toxicity of phenolic compounds to aquatic biota: Archives of Environmental Contamination and Toxicology, v. 9, p. 557-568.

deNoyelles, Frank, Jr., and Kettle, W.D., 1985, Experimental ponds for evaluating bioassay predictions, in Boyle, T.P., ed., Validation and predictability of laboratory methods for assessing the fate and effects of contaminants in aquatic ecosystems: Philadelphia, American Society for Testing and Materials, Special Technical Publication 865, p. 91-103. 
Devlin, E.W., Brammer, J.D., and Puyear, R.L., 1982, Acute toxicity of toluene to three age groups of fathead minnows (Pimephales promelas): Bulletin of Environmental Contamination and Toxicology, v. 29, p. 12-17.

Devlin, E.W., Brammer, J.D., and Puyear, R.L., 1985, Effect of tuluene on fathead minnow (Pimephales promelas Rafinesque) development: Archives of Environmental Contamination and Toxicology, v. 14, p. 595-603.

DeVries, P.J.R., and Hotting, E.J., 1985, Bioassays with Stigeoclonium tenue Kutz on waters receiving sewage effluent: Water Research, v. 19, no. 11. p. $1,405-1,410$.

DeZwart, D. and Sloof, W., 1983, The Microtox as an alternative assay in the acute toxicity assessment of water pollutants: Aquatic Toxicology, v. 4, p. 129-138.

Diks, D.M., and Allen, H.E., 1983, Correlation of copper distribution in a freshwater-sediment system to bioavailability: Bulletin of Environmental Contamination and Toxicology, v. 30, no. 1, p. 37-43.

Dill, D.C., Mayes, M.A., Mendoza, C.G., Boggs, G.U., and Emmitte, J.A., 1982, Comparison of the toxicities of biphenyl, monochlororobiphenyl, and 2,2',4,4'-tetrachlorobiphenal to fish and daphnids, in Pearson, J.G., Foster, R.B., and Bishop, W.E., eds., Aquatic toxicology and hazard assessment: Philadelphia, Fifth Conference, American Society for Testing and Materials, Special Techinical Publication 766, p. 245-256.

Dutka, B.J., and Kwan, K.K., 1981, Comparison of three microbial toxicity screening tests with the Microtox test: Bulletin of Environmental Contamination and Toxicology, v. 27, p. 753-757. Dutka, B.J., and Kwan, K.K., 1982, Application of four bacterial screening procedures to assess changes in the toxicity of chemicals in mixtures: Environmental Pollution (Series A), v. 29, p. 125-134.

Dutka, B.J., Nyholm, N., and Petersen, J., 1983, Comparison of several microbiological toxicity screening tests: Water Research, v. 17., no. 10 , p. $1,363-1,368$.

Dutka, B.J., Walsh, K., Kwan, K.K., El Shaarawi, A., Liu, D.L., and Thompson, K., 1986, Priority site selection for degraded areas based on microbial and toxicant screening tests: Water Pollution Research Journal of Canada, v. 21, no. 2, p. 267-282.

Eaton, J.G., 1973, Recent developments in the use of laboratory bioassays to determine "safe" levels of toxicants for fish, in Glass, G.E., ed., Bioassay techniques and environmental chemistry: Ann Arbor, Michigan, Ann Arbor Science Publishers, chap. 4, p. 107-115.

Elder, J.F., and Dresler, P.V., 1988, Accumulation and bioconcentration of polycyclic aromatic hydrocarbons in a nearshore estuarine environment near a Pensacola (Florida) creosote contamination site: Environmental Pollution, v. 49, no. 2, p. 117-132. 
Elnabarawy, M.T., Welter, A.N., and Robidean, R.R., 1986, Relative sensitivity of three daphnid species to selected organic and inorganic chemicals: Environmental Toxicology and Chemistry, v. 5, no. 4, p. 393-398.

Eloranta, V.A., and Halttunen-Keyrilainen, Liisa, 1984, A comparison of the Selenastrum bottle test and the natural phytoplankton assay in algal toxicity tests: Archiv fur Hydrobiologie, Supplement 67, p. 447-459.

Feder, P.E., and Collins, W.J., 1982, Considerations in the design and analysis of chronic aquatic tests of toxicity, in Pearson, J.G., Foster, R.B., and Bishop, W.E., eds., Aquatic toxicology and hazard assessment: Philadelphia, Fifth Conference, American Society for Testing and Materials, Special Technical Publication 766, p. 32-68.

Feltz, H.R., 1980, Significance of bottom material data in evaluating water quality, in Baker, R.A., ed., Contaminants and sediments, Volume 1, Fate and transport, case studies, modeling, toxicity: Ann Arbor, Michigan, Ann Arbor Science Publishers, chap. 11, p. 271-287.

Finger, S.E., Little, E.F., Henry, M.G., Fairchild, J.F., and Boyle, T.P., 1985. Comparison of laboratory and field assessment of flourene---part I: effects of flourene on the survival, growth, reproduction, and behavior of aquatic organisms in laboratory tests, in Boyle, T.P., ed., Validation and predictability of laboratory methods for assessing the fate and effects of contaminants in aquatic ecosystems: Philadelphia, American Society for Testing and Materials, Standard Technical Publication 865 , p. 120-133.

Fisher, J.W., Harrah, C.B., D'Allessandris, R., Collins, G. T., Muhic, L. A., Umina, J.F., Blanchard, R.E., and Klosterman, E.L., 1982, A monitoring technique for assessing effects of pollutants on fish activity, in Pearson, J.G., Foster, R.B., and Bishop, W.E., eds., Aquatic toxicology and hazard assessment: Philadelphia, Fifth Conference, American Society for Testing and Materials, Special Technical Publication 766, p. 196-205.

Foe, Christopher, and Knight, Allen, 1987, Assessment of the biological impact of point source discharges employing Asiatic clams: Archives of

Environmental Contamination and Toxicology, v. 16, no. 1, p. 39-51.

Foran, J.A., Germuska, P.J., and Delfine, J.J., 1985, Acute toxicity of aldicarb, aldicarb sulfoxide, and aldicarb sulfone to Daphnia laevis: Bulletin of Environmental Contamination and Toxicology, v. 35, no. 4 , p. 546-550.

Foureman, G.L., White, N.B., Jr., Bend, J.R., 1983, Biochemical evidence that winter flounder (Pseudopleuronectes americanus) have induced hepatic glochrome P-450-dependant monooxygenase activities: Canadian Journal of Fisheries and Aquatic Sciences, v. 40, no. 7, p. 854-865. 
Freeman, M.C., 1986, Aquatic toxicity tests: Comparative assessment of four acute tests and their potential application in New Zealand: Wellington, New Zealand, National Water and Soil Conservation Organization, Water and Soil Technical Publication no. 28, 36 p.

Fremling, C.R., and Mauck, W.L., 1980, Methods for using nymphs of burrowing mayflies (Ephemeroptera hexagenia) as toxicity test organisms, in Buikema, A.L., Jr., and Cairns, John, Jr., eds., Aquatic invertebrate bioassays: Philadelphia, American Society for Testing and Materials, Special Technical Publication 715, p. 81-97.

Fuller, S.L.H., 1974, Clams and mussels (Mollusca: Bivalvia), in Hart, C.W., and Fuller, S.L.H., eds., Pollution ecology of freshwater invertebrates: New York, Academic Press, p. 215-274.

Gaur, J.P. and Kumar, H.D., 1981, Growth response of four micro-algae to three crude oils and furnace oil: Environmental Pollution (Series A), v. 25, no. 1 , p. 77-85.

Gaur, J.P. and Kumar, H.D., 1986, Effects of oil refinery effluents on Selenastrum capricornutum Printz: Internationale Revue Gesamten Hydrobiologie, v. 71, no. 2, p. 271-281.

Geiger, J.G., and Buikema, A.L., Jr., 1981, Oxygen consumption and filtering rate of Daphnia pulex after exposure to water-soluble fractions of naphthalene, phenanthrene, No. 2 fuel oil, and coal-tar creosote: Bulletin of Environmental Contamination and Toxicology, v. 27, no. 6, p. 783-789.

Geiger, J.G., Buikema, A.I., Jr., and Cairns, John, Jr., 1980, A tentative seven-day test for predicting effects of stress on populations of Daphnia pulex, in Eaton,..J.G., Parrish, P.R., and Hendricks, A.C., eds., Aquatic toxicology: Philadelphia, American Society for Testing and Materials, Special Technical Publication 707, p. 13-26.

Gersich, F.M., and Mayes, M.A., 1986, Acute toxicity tests with Daphnia magna Straus and Pimephales promelas Rafinesque in support of national pollutant discharge elimination permit requirements: Water Research, v. 20 , no. 7 , p. 939-941.

Giddings, J.M., 1986, A microcosm procedure for determining safe levels of chemical exposure in shallow-water communities, in Cairns, John, Jr., ed., Community toxicity testing: Philadelphia, American Society for Testing and Materials, Special Technical Publication 920, p. 121-134.

Giddings, J.M., and Franco, P.J., 1985, Calibration of laboratory bioassays with results from microcosms and ponds, in Boyle, T.P., ed., Validation and predictability of laboratory methods for assessing the fate and effects of contaminants in aquatic ecosystems: Philadelphia, American Society for Testing and Materials, Special Technical Publication 865, p. 104-119. 
Giddings, J.M., Stewart, A.J., O'Neill, R.V., and Gardner, R.H., 1983, An efficient algal bioassay based on short-term photosynthetic response, in Bishop, W.E., Cardwell, R.D., and Heidolph, B.B., eds., Aquatic toxicology and hazard assessment: Philadelphia, Sixth Symposium, American Society for Testing and Materials, Special Technical Publication 802 , p. $445-459$.

Goldman, C.R., and Horne, A.J., 1983, LimnologY: New York, McGraw-Hill, 464 p.

Goodman, L.R., Hansen, D.J., Manning, C.S., and Faas, L.F., 1982, Effects of kepone on the sheepshead minnow in an entire life-cycle toxicity test: Archives of Environmental Contamination and Toxicology, v. 11, p. 335342 .

Goulden, C.E., Comotto, R.M., Hendrickson, J.A., Jr., Hornig, L.L., and Johnson, K.L., 1982, Procedures and recomendations for the culture and use of daphnia in bioassay studies, in Pearson, J.G., Foster, R.B., and Bishop, W.E., eds., Aquatic toxicology and hazard assessment: Philadelphia, Fifth Conference, American Society for Testing and Materials, Special Techinical Publication 766, p. 139-160.

Graney, R.L., Jr., Cherry, D.S., and Cairns, John, Jr., 1984, The influence of substrate, $\mathrm{pH}$, diet and temperature upon cadmium accumulation in the Asiatic clam (Corbicula fluminea) in laboratory artificial streams: Water Research, v. 18, no. 7, p. 833-842.

Graney, R.L., and Giesy, J.P., Jr., 1987, The effect of short-term exposure to pentachlorophenol and osmotic stress on the free amino acid pool of the freshwater amphipod Gammarus Pseudolimnaeus Bousfield: Environmental Contamination and Toxicology, v. 16, p. 167-176.

Greene, J.C., Miller..W.E., Debacon, M.K., Long, M.A., and Bartels, C.L., 1985, A comparison of three microbial assay procedures for measuring toxicity of chemical residues: Archives of Environmental Contamination and Toxicology, v. 14, p. 659-667.

Greene, J.C., Soltero, R.A., Miller, W.E., Gasperino, A.F., and Shirogama, T., 1976. The relationship of laboratory algal assays to measurements of indigenous phytoplankton in Long Lake, Washington, in Middlebrooks, E.J., Falkenborg, D.H., and Maloney, T.E., eds., Biostimulation and nutrient assessment: Ann Arbor, Michigan, Ann Arbor Science, p. 93-126.

Gruber, D., Dickson, K.L., Hendricks, A.C., and Miller, W.R. III, 1980, An automated biological monitoring facility for rapidly and continuously assessing industrial effluents, in Eaton, J.G., Parrish, P.R., and Hendricks, A.C., eds., Aquatic toxicology: Philadelphia, American Society for Testing and Materials, Special Technical Publication 707, p. 164-176.

Gruber, D., and Cairns, John, Jr., 1981, Industrial effluent monitoring incorporating a recent automated fish biomonitoring system: Water, Air, and Soil Pollution, v. 15, p. 471-481. 
Haight, M., Mudry, T., and Pasternak, J., 1982, Toxicity of seven heavy metals on Panagrellus silusiae: The efficacy of the free-living nematode as an in vivo toxicological bioassay: Nematologica, v. 28, no. 1, p. 1-11.

Hamala, J.A., and Kollig, H.P., 1985, The effects of atrazine on periphyton communities in controlled laboratory ecosystems: Chemosphere, v. 14, no. 9, p. 1,391-1,408.

Hansen, D.J., and Tagatz, M.E., 1980, A laboratory test for assessing impacts of substances on developing communities of benthic estuarine organisms, in Eaton, J.G., Parrish, P.R., and Hendricks, A.C., eds., Aquatic toxicology: Philadelphia, American Society for Testing and Materials, Special Technical Publication 707, p. 40-57.

Hansen, S.R., and Garton, R.R., 1982, Ability of standard toxicity tests to predict effects of the insecticide diflubenzuron on laboratory stream communities: Canadian Journal of Fisheries and Aquatic Sciences, v. 39, p. $1,273-1,288$.

Harrass, M.C., and Taub, F.B., 1985, Comparison of laboratory microcosms and field responses to copper, in Boyle, T.P., ed., Validation and predictability of laboratory methods for assessing the fate and effects of contaminants in aquatic ecosystems: Philadelphia, American Society for Testing and Materials, Special Technical Publication 865, p. 57-74.

Harrison, F.L., Knezovich, J.P., and Rice, D.W. Jr., 1984, The toxicity of copper to the adult and early life stages of the freshwater clam, Corbicula manilensis: Archives of Environmental Contamination and Toxicology, v. 13, p. 85-92.

Hartman, W.A., and Martin, D.B., 1985, Effects of four agricultural pesticides on Daphnia pulex, Lemna minor, and potamogeton pectinatus: Bulletin of Environmental Contamination and Toxicology, v. 35, p. 646-651.

Hattula, M.L., Wasenius, V.M., Reunanen, H., and Arstila, A.U., 1981, Acute toxicity of some chlorinated phenols, catechols, and cresols to trout: Bulletin of Environmental Contamination and Toxicology, v. 26, no. 3, p. 295-298.

Hedtke, S.F., 1984, Structure and function of copper-stressed aquatic microcosms: Aquatic Toxicology, v. 5, p. 227-244.

Hedtke, S.F., and Arthur, J.W., 1985, Evaluation of site-specific water quality criterion for pentachlorophenol using outdoor experimental streams, in Cardwell, R.D., Purdy, R., and Bahner, R.C., eds., Aquatic toxicology and hazard assessment: Philadelphia, Seventh Symposium, American Society for Testing and Materials, Special Technical Publication 854 , p. 551-564. 
Hemelraad, J., Kleinveld, H.A., deRoos, A.M., Holwerda, D.A., and Zandee, D.I., 1987, Cadmium kinetics in freshwater clams. III. Effects of zinc on uptake and distribution of cadmium in Anodonta cygnea: Archives of Environmental Contamination and Toxicology, v. 16, no. 1, p. 95-101.

Herman, David, Kaushik, N.K., and Solomon, K.R., 1986, Impact of atrazine on periphyton in freshwater enclosures and some ecological consequences: Canadian Journal of Fisheries and Aquatic Sciences, v. 43, no. 10 , p. $1,917-1,925$.

Hermens, Joop, Canton, Hans, Steyger, Niek, and Wegman, Ronald, 1984, Joint effects of a mixture of 14 chemicals on mortality and inhibition of reproduction of Daphnia magna: Aquatic Toxicology, v. 5, p. 315-322.

Hinton, D.E., Kendall, M.W., and Silver, B.B., 1973, Use of histologic and histochemical assessments in the prognosis of the effects of aquatic pollutants, in Cairns, John Jr., and Dickson, K.L., eds., Biological methods for the assessment of water quality: Philadelphia, American Society for Testing and Materials, Special Technical Publication 528, p. 194-208.

Hinton, D.E., Klaunig, J.E., Jack, R.M., Lipsky, M.M., and Trump, B.F., 1981, In vitro evaluation of the channel catfish Ictalurus punctatus (Rafinesque) as a test species in chemical carcinogenesis studies, in Branson, D.R., and Dickson, K.L., eds., Aquatic toxicology and hazard assessment: Philadelphia, Fourth Conference, American Society for Testing and Materials, Special Technical Publication 737, p. 226-238.

Hobbs, H.H., Jr., and Hall, E.T., Jr., 1974, Crayfishes (Decapoda: Astacidae), in Hart, C.W., and Fuller, S.L.H., eds., Pollution ecology of freshwater invertebrates: New York, Academic Press, p. 195-214.

Hodson, P.V., Blunt, B.R., Spry, D.J., and Austen, Keith, 1977, Evaluation of erythrocyte 5-amino leulinic acid dehydratase activity as a short-term indicator in $f$ ish of a harmful exposure to lead: Journal of the Fisheries Research Board of Canada, v. 34, no. 4, p. 501-508.

Hodson, P.V., Blunt, B.R., and Spry, D.J., 1978, pH-induced changes in blood lead of lead-exposed rainbow trout: Journal of the Fisheries Research Board of Canada, v. 35, no. 4, p. 437-445.

Honig, R.A., and Buikema, A.L., Jr., 1980, Evaluating promulgated refinery effluent standards using artificial streams: Archives of Environmental Contamination and Toxicology, v. 9, p. 607-618.

Honig, R.A., McGinniss, M.J., Buikema, A.L., Jr., and Cairns, John, Jr., 1980, Toxicity tests of aquatic pollutants using Chilomonas paramecium Ehrenberg (flagellata) populations: Bulletin of Environmental Contamination and Toxicology, v. 25, p. 169-175.

Horne, R.A., 1978, The chemistry of our environment: New York, WileyInterscience, 869 p. 
Horning, W.B., II, and Weber, C.I., eds., 1985, Short-term methods for estimating the chronic toxicity of effluents and receiving waters to freshwater organisms: U.S. Environmental Protection Agency 600/4-85/014.

Hutchinson, G.E., 1953, The concept of pattern in ecology: Proceedings of the Academy of National Sciences, v. 105, p. 1-12.

Iwan, G.R., and Cella, G.E., 1981, On-site critical life-stage bioassay with the fathead minnow, Pimephales promelas, on effluent from the wastewater treatment facilities of Austin, Minn., in Branson, D.R., and Dickson, K.L., eds., Aquatic toxicology and hazard assessment: Philadelphia, Fourth Conference, American Society for Testing and Materials, Special Technical Publication 737, p. 312-323.

Jenkins, K.D., and Sanders, B.M., 1986, Assessing the biological effects of anthropogenic contaminants in situ, in Urbonas, Ben, and Roesner, L. A., eds., Urban runoff quality: impact and quality enhancement technology, proceedings of an Engineering Foundation Conference, New England College, Henniker, New Hampshire, June 23-27, 1986, American Society of Civil Engineering, New York, New York.

Jop, K.M., Rodgers, J.H., Jr., Price, E.E., and Dickson, K.L., 1986, Renewal device for test solutions in daphnia toxicity tests: Bulletin of Environmental Contamination and Toxicology, v. 36, p. 95-100.

Joubert, Gerald, 1983, Detailed method for quantitative toxicity measurements using the green algae Selenastrum capricornutum, in Nriagu, J.0., ed., Aquatic toxicology: New York, John Wiley and Sons, ch. 17, p. 467-486.

Judy, R.D., Jr., and Davies, P.H., 1979, Effects of calcium addition as $\mathrm{Ca}(\mathrm{NO} 3) 2$ on zinc toxicity to fathead minnows, Pimephales promelas, Rafinesque: Bulletin of Environmental Contamination and Toxicology, v. 22, p. $88-94$.

Kallqvist, T., 1984, The application of an algal assay to assess toxicity and eutrophication in polluted streams, in Cardiff, U.K., Pasco, E.D., and Edwards, R.W., eds., Freshwater biological monitoring: Proceedings of Symposium, September 12-14, 1984, International Association on Water Pollution Research and Control, Pergamon, New York, p. 121-129.

Katz, Bernice, 1979, Relationship of the physiology of aquatic organisms to the lethality of toxicants: A broad overview with emphasis on membrane permeability, in Marking, L.L., and Kimerle, R.A., eds., Aquatic toxicology: philadelphia, American Society for Testing and Materials, Special Technical Publication 667, p. 62-76.

Kaushik, N.K., Stephenson, G.L., Solomon, K.R., and Day, K.E., 1985, Impact of permethrin on zooplankton communities in limnocorrals: Canadian Journal of Fisheries and Aquatic Sciences, v. 42, p. 77-85. 
Kaushik, N.K., Solomon, K.R., Stephenson, G.L., and Day, K.E., 1986, Use of limnocorrals in evaluating the effects of pesticides on zooplankton communities, in Cairns, John, Jr., ed., Community toxicity testing: Philadelphia, American Society for Testing and Materials, Special Technical Publication 920, p. 269-290.

Kay, S.H., Haller, W.T., and Garrard, L.A., 1984, Effects of heavy metals on water hyacinths (Eichhornia crassipes (Mart.) Solms): Aquatic toxicology, v. 5, p. 117-128.

Keating, K.I., 1985, A system of defined (Sensu stricto) media for daphnid (Cladocera) culture: Water Research, v. 19, no. 1, p. 73-78.

Keefe, D.F., Nimmo, D.R., Baldridge, Duaina, and Iley, Gene, Jr., 1983, Field investigations and on-site toxicity testing: an assessment of habitat suitability---Arkansas River, Pueblo, Colorado, in Bishop, W.E., Cardwell, R.D., and Heidolph, B.B., eds., Aquatic toxicology and hazard assessment: Philadelphia, Sixth Symposium, American Society for Testing and Materials, Special Technical Publication 802, p. 216-238.

Keen, Robert, and Baillod, C.R., 1985, Toxicity to Daphnia of the end products of wet oxidation of phenol and substituted phenols: Water Research, v. 19 , no. 6, p. 767-772.

Kenaga, E.E., 1978, Test organisms and methods useful for early assessment of acute toxicity of chemicals: Environmental Science and Technology, v. 12 , no. 12 , p. $1,322-1,329$.

Kettle, W.D., deNoyelles, F., Jr., and Lei, C-H., 1980, Oxygen consumption of zooplankton as affected by laboratory and field cadmium exposures: Bulletin of Environmental Contamination and Toxicology, v. 25, p. 547553.

Kimball, K.D., and Levin, S.A., 1985, Limitations of laboratory bioassays, and the need for ecosystem-level testing: BioScience, v. 35, no. 3., p. 165-171.

Kindig, A.C., Conquest, L.L., and Taub, F.B., 1983, Differential sensitivity of new versus mature synthetic microcosms to streptomycin sulfate treatment, in Bishop, W.E., Cardwell, R.D., and Heidolph, B.B., eds., Aquatic toxicology and hazard assessment: Philadelphia, Sixth Symposium: American Society for Testing and Materials, Special Technical Publication 802 , p. $192-203$.

King, J.M., and Coley, K.S., 1985, Toxicity of aqueous extracts of natural and synthetic oils to three species of Lemna, in Bahner, R.C., and Hansen, D.J., eds., Aquatic toxicology and hazard assessment: Philadelphia, Eighth Symposium, American Society for Testing and Materials, Special Technical Publication 891, p. 302-309. 
Kleerekoper, Herman, 1977, Some monitoring and analytical techniques for the study of locomotor responses of fish to environmental variables, in Cairns, John, Jr., Dickson, K.L., and Westlake, G.F., eds., Biological monitoring of water and effluent quality: Philadelphia, American Society for Testing and Materials, Special Technical Publication 607, p. 110-120.

Kline, E.R., Mattson, V.R., Pickering, Q.H., Spehar, D.L., and Stephan, C.E., 1987, Effects of pollution on freshwater organisms: Journal of the Water Pollution Control Federation, v. 59, no. 6, p. 539-572.

Kuivasniemi, Kaija, Eloranta, Varpu, and Knuutinen, Juha, 1985, Acute toxicity of some chlorinated phenolic compounds to Selenastrum capricornutum and phytoplankton: Archives of Environmental Contamination and Toxicology, v. 14, p. 43-49.

Kurelec, B., Britvic, S., Muller, W.E.G., and Zahn, B.K., 1977, Benzo(a)pyrene monooxygenase induction in marine fish---molecular response to oil pollution: Marine Biology, v. 44, p. 211-216.

Lafont, Michel, 1984, Oligochaete communities as biological descriptors of pollution in the fine sediments of rivers: Hydrobiologia, v. 115, p. 127-129.

Larsen, D.P., DeNoyelles, Frank, Jr., Stay, Frank, and Shiroyama, Tamotsu, 1986, Comparisons of single-species, microcosm and experimental pond responses to atrazine exposure: Environmental Toxicology and Chemistry, v. 5 , no. 2 , p. 179-190.

Laskowski-Hoke, R.A., and Prater, B.L., 1981, Relationship of mortality of aquatic biota from 96-hour sediment bioassays and the change in chemical composition of the test water: Bulletin of Environmental Contamination and Toxicology, v. 26, p. 323-327.

LeBlanc, G.A., 1980, Acute toxicity of priority pollutants to water flea (Daphnia magna): Bulletin of Environmental Contamination and Toxicology, v. 24 , no. 5, p. 684-691.

LeBlanc, G.A., 1984, Interspecies relationships in acute toxicity of chemicals to aquatic organisms: Environmental Toxicology and Chemistry, v. 3, no. 1, p. 47-60.

LeBlanc, G.A., Schoenfeld, D.A., and Surprenant, D.C., 1983, Effects of food concentration, animal interactions, and water on survival, growth, and reproduction of Daphnia magna under flow-through conditions, in Bishop, W.E., Cardwell, R.D., and Heidolph, B.B., eds., Aquatic toxicology and hazard assessment: Philadelphia, Sixth Symposium, American Society for Testing and Materials, Special Technical Publication 802, p. 494-508. 
LeBlanc, G.A., and Suprenant, D.C., 1985, A method of assessing the toxicity of contaminated freshwater sediments, in Cardwell, R.D., Purdy, R., and Bahner, R.C., eds., Aquatic toxicology and hazard assessment: Philadelphia, Seventh Symposium, American Society for Testing and Materials, Special Technical Publication 854, p. 269-283.

Lebsack, M.E., Anderson, A.D., DeGraeve, G.M., and Bergman, H.L., 1981, Comparison of bacterial luminescence and $f$ ish bioassay results for fossil-fuel process waters and phenolic constituents, in Branson, D.R., and Dickson, K.L., eds., Aquatic toxicology and hazard assessment: Phildelphia, Fourth Conference, American Society for Testing and Materials, Special Technical Publication 737, p. 348-356.

Lech, J.J., Vodicnik, M.J., and Elcombe, C.R., 1982, Aquatic toxicology: New York, Raven Press, p. 107-148.

Lee, D.R., and Buikema, A.L., Jr., 1979, Molt-related sensitivity of Daphnia pulex in toxicity testing: Journal of the Fisheries Research Board of Canada, v. 36, no. 9, p. 1,129-1,133.

Lee, G.F., and Jones, R.A., 1983, Translation of laboratory results to field conditions: the role of aquatic chemistry in assessing toxicity, in Bishop, W.E., Cardwell, R.D., and Heidolph, B.B., eds., Aquatic toxicology and hazard assessment: Philadelphia, Sixth Symposium, American Society for Testing and Materials, Special Technical Publication 802 , p. 328-349.

Leeuwangh, P., 1978, Toxicity tests with daphnids: its application in the management of water quality: Hydrobiologia, v. 59, no. 2, p. 145-148.

Leland, H.V., and Carter, J.L., 1985, Effects of copper on production of periphyton, nitrogen fixation and processing of leaf litter in a sierra Nevada, California, stream: Freshwater Biology, v. 15, no. 2, p. 155173 .

Levy, Don, Lockett, Gregg, Oldfather, Joan, Rees, John, Saegebarth, Ellen, Schneider, Richard, and Harte, John, 1985, Realism and replicability of lentic freshwater microcosms, in Boyle, T.P., ed., Validation and predictability of laboratory methods for assessing the fate and effects of contaminants in aquatic ecosystems: Philadelphia, American Society for Testing and Materials, Standard Technical Publication 865, p. 43-56.

Lewis, P.A., and Weber, C.I., 1985, A study of the reliability of Daphnia acute toxicity tests, in Cardwell, R.D., Purdy, R., and Bahner, R.C., eds., Aquatic toxicology and hazard assessment: Philadelphia, Seventh Symposium, American Society for Testing and Materials, Special Technical Publication 854 , p. 73-86.

Livingston, R.J., and Meeter, D.A., 1985, Correspondence of laboratory and field results: what are the criteria for verification?, in Cairns, John, Jr., ed., Multispecies toxicity testing: New York, Pergamon Press, Society for Environmental Toxicology and Chemistry, p. 76-88. 
Lockhart, W.L., Billeck, B.N., de March, B.G.E., and Muir, D.C.G., 1983, Uptake and toxicity of organic compounds: studies with an aquatic macrophyte (Lemna minor), in Bishop, W.E., Cardwell, R.D., and Heidolph, B.B., eds., Aquatic toxicology and hazard assessment: Philadelphia, Sixth Symposium, American Society for Testing and Materials, Special Technical Publication 802, p. 460-468.

Long, E.R., and Chapman, P.M., 1985, A sediment quality triad: measures of sediment contamination, toxicity, and infaunal community composition in Puget Sound: Marine Pollution Bulletin, v. 16, no. 10, p. 405-415.

Luoma, S.N., 1977, Detection of trace contaminant effects in aquatic ecosystems: Journal of the Fisheries Research Board of Canada, v. 34, no. 3 , p. 436-439.

Macek, K.J., 1975, Acute toxicity of pesticide mixtures to bluegills: Bulletin of Environmental Contamination and Toxicology, v. 14, no. 6, p. 648-652.

Macek, Kenneth, Birge, Wesley, Mayer, F.L., Buikema, A.L. Jr., and Maki, A.W., 1978, Discussion session synopsis, in Cairns, John, Jr., Dickson, K.L., and Maki, A.W., eds., Estimating the hazard of chemical substances to aquatic life: Philadelphia, American Society for Testing and Materials, Special Technical Publication 657, p. 27-32.

Maciorowski, H.D., and Clarke, R.M., 1980, Advantages and disadvantages of using invertebrates in toxicity testing, in Buikema, A.L., Jr., and Cairns, John, Jr. eds., Aquatic invertebrate bioassays: Philadelphia, American Society for Testing and Materials, Special Technical Publication 715 , p. 36-47.

Maki, A.W., 1979, Respiratory activity of fish as a predictor of chronic fish toxicity values for surfactants, in Marking, L.L., and Kimerle, R.A., eds., Aquatic toxicology: Philadelphia, American Society for Testing and Materials, Special Technical Publication 667, p. 77-95.

Malueg, K.W., Schuytema, G.S., Krawczyk, D.F., and Gakstatter, J.H., 1984a, Laboratory sediment toxicity tests, sediment chemistry and distribution of benthic macroinvertebrates in sediments from the Keweehaw Waterway, Michigan: Environmental Toxicology and Chemistry, v. 3, p. 233-242.

Malueg, K.W., Schuytema, G.S., Krawczyk, D.F., and Gakstatter, J.H., 1984b, Toxicity of sediments from three metal-contaminated areas: Environmental Toxicology and Chemistry, v. 3, p. 279-291.

Marshall, J.S., 1978, , Field verification of cadmium toxicity to laboratory daphnia populations: Bulletin of Environmental Contamination and Toxicology, v. 20, p. 387-393.' 
Marshall, J.S., and Mellinger, D.L., 1980, An in situ experimental method for toxicological studies on natural plankton communities, in Eaton, J.G., Parrish, P.R., and Hendricks, A.C., eds. Aquatic toxicology:

Philadelphia, American Society for Testing and Materials, Special Technical Publication 707, p. 27-39.

Martin, T.R., and Holdich, D.M., 1986, The acute lethal toxicity of heavy metals to peracarid crustaceans (with particular reference to fresh-water Asellids and Gammarids): Water Research, v. 20, no. 9, p. 1,137-1,147.

Mason, C.F., 1981, Biology of freshwater pollution, Techniques for intrusive micro-organisms and bioassays, Longman Group Ltd., Essex, England, Chapter 7, p. 166-183.

Mayes, M.A., Blanchard, F.A., Hopkins, D.L., and Takahashi, I.T., 1985, Static acute toxicity of dibromonitrilopropionamide and selected degradation products to the fathead minnow (Pimephales promelas Rafinesque): Environmental Toxicology and Chemistry, v. 4, no. 6, p. 823-830.

McFeters, G.A., Bond, P.J., Olson, S.B., and Tchan, Y.T., 1983, A comparison of microbial bioassays for the detection of aquatic toxicants: Water Research, v. 17, no. 12, p. 1,757-1,762.

McKim, J.M., 1977, Evaluation of tests with early life stages of fish for predicting long-term toxicity: Journal of the Fisheries Research Board of Canada, v. 34 , no. 8, p. 1,148-1,154.

McKim, J.M., Schmieder, P.K., Carlson, R.W., Hunt, E.P., and Niemi, G.J., 1987(a), Use of respiratory-cardiovascular responses of rainbow trout (Salmo gairdneri) in identifying acute toxicity syndromes in fish: Part I, pentachlorphenol, 2,4-dinitrophenol, tricaine methansulfonate and 1octanol: Environmental Toxicology and Chemistry, v. 6, no. 4, p. 295312 .

McKnight, D.M., 1980, Copper complexation by siderophores from filamentous blue-green algae: Limnology and Oceanography, v. 25, no. 1, p. 62-71.

McNaught, D.C., and Mount, D.E., 1985, Appropriate durations and measures for Ceriodaphnia toxicity tests, in Bahner, R.C., and Hansen, D.J., eds., Aquatic toxicology and hazard assessment: Philadelphia, Eighth Symposium, American Society for Testing and Materials, Special Technical Publication 891, p. 375-381.

Meador, J.P., U'ren, S.C., and Salazar, M.H., 1984, A flow-through bioassay system for the evaluation of organotin antifouling compounds: Water Research, v. 18 , no. 5, p. 647-650.

Mearns, A.J., Swartz, R.C., Cummins, J.M., Dinnel, P.A., Plesha, P., and Chapman, P.M., 1986, Inter-laboratory comparison of a sediment toxicity test using the marine amphipod, Rhepoxynius abronius: Marine

Environmental Research, v. 19, p. 13-37. 
Meglitsch, P.A., 1967, Invertebrate zoology: London, Oxford University Press, 961 p.

Meyerhoff, R.D., Grothe, D.W., Sauter, S., and Dorulla, G.K., 1985, Chronic toxicity of tebuthiuron to an alga (Selenastrum capricornutum), a cladoceran (Daphnia magna), and the fathead minnow (Pimephales promelas): Environmental Toxicology and Chemistry, v. 4, no. 5, p. 695-701.

Michnowicz, C.J., and Weaks, T.E., 1984, Effects of $\mathrm{pH}$ on toxicity of As, Cr, $\mathrm{Cu}, \mathrm{Ni}$, and $\mathrm{Zn}$ to Selenastrum capricornutum Printz: Hydrobiologia, v. 118 , p. 299-305.

Miller, W.E., Greene, J.C., and Shiroyama, Tamotsu, 1978, The Selenastrum capricornutum Printz algal assay bottle test: U.S. Environmental Protection Agency Report, EPA-600/9-78-018, Corvallis, Oregon, 125 p.

Mitchell, Ralph, 1974, Introduction to environmental microbiology: Englewood Cliffs, New Jersey, Prentice-Hall, 355 p.

Morgan, W.S.G., 1977, An electronic system to monitor the effects of changes in water quality on fish opercular rhythms, in Cairns, John, Jr., Dickson, K.L., and Westlake, G.F. eds., Biological monitoring of water and effluent quality, American Society for Testing and Materials, Special Technical Publication 607, p. 38-55.

Mount, D.I., 1985, Scientific problems in using multispecies toxicity tests for regulatory purposes, in Cairns, John, Jr., ed., Multispecies toxicity testing: New York, Pergamon Press, Society for Environmental Toxicology and Chemistry, p. 13-18.

Mount, D. E., and Brungs, W. A., 1967, A simplified dosing apparatus for fish toxicity studies: Water Research, v. 1, p. 21-29.

Mount, D.I., and Norberg, T.J., 1984, A seven-day life-cycle cladoceran toxicity test: Environmental Toxicology and Chemistry, v. 3, p. 425-434.

Mount, D.I., and Norberg-King, T.J., eds., 1985, Validity of effluent and ambient toxicity tests for predicting biological impact, Scippo Creek, Circleville, Ohio: U.S. Environmental Protection Agency, Washington, D.C. , EPA/600/3-85/044.

Mount, D.I., Thomas, N.A., Norberg, T.J., Barbour, M.T., Roush, T.H., and Brandes, W.F., 1984, Effluent and ambient toxicity testing and instream community response on the Ottawa River, Lima, Ohio: United States Environmental Protection Agency, Washington, D.C., EPA- 600/3-84-080.

Murty, A.S., 1986, Toxicity of pesticides to fish: Boca Raton, Florida, CRC Press, v. 1, 235 p. 
Nasu, Yukata, and Kugimoto, Mamoru, 1981, Lemna (duckweed) as an indicator of water pollution. I. the sensitivity of Lemna paucicostata to heavy metals: Archives of Environmental Contamination and Toxicology, v. 10, p. 159-169.

Nebeker, A.V., Savonen, Carol, and Stevens, D.G., 1985, Sensitivity of rainbow trout early life stages to nickel chloride: Environmental Toxicology and Chemistry, v. 4, p. 233-239.

Nebeker, A.V., 1982, Evaluation of a Daphnia magna renewal life-cycle test method with silver and endosulfan: Water Research, v. 16, p. 739-744.

Nebeker, A.V., Cairns, M.A., Gakstatter, J.H., Malueg, K.W., Schuytema, G.S., and Krawczyk, D.F., 1984, Biological methods for determining toxicity of contaminated freshwater sediments to invertebrates: Environmental Toxicology and Chemistry, v. 3, no. 4, p. 617-630.

Nebeker, A.V., Cairns, M.A., and Wise, C.M., 1984, Relative sensitivity of Chironomus tentans life stages to copper: Environmental Toxicology and Chemistry, v. 3, no. 1, p. 151-158.

Nebeker, A.V., McAuliffe C.K., Mshar, Roger, and Stevens, D.G., 1983, Toxicity of silver to steelhead and rainbow trout, fathead minnows, and Daphnia magna: Environmental Toxicology and Chemistry, v. 2, p. 95-104.

Nebeker, A.V., Savonen, Carol, and Stevens, D.G., 1985, Sensitivity of rainbow trout early life stages to nickel chloride: Environmental Toxicology and Chemistry, v. 4, p. 233-239.

Neff, J.M., 1985, Use of biochemical measurements to detect pollutant-mediated damage to fish, in Cardwell, R.D., Purdy, R., and Bahner, R.C., eds., Aquatic toxicology and hazard assessment: Philadelphia, Seventh Symposium, American Society for Testing and Materials, Special Technical Publication 854 , p. 155-183.

Nehring, R.B., and Goettl, J.P., 1974, Acute toxicity of a zinc-polluted stream to four species of salmonids: Bulletin of Environmental Contamination and Toxicology, v. 12, no. 4, p. 464-469.

Niimi, A.J., 1983, Biological and toxicological effects of environmental contaminants in fish and their eggs: Canadian Journal of Fisheries and Aquatic Sciences, v. 40, no. 3, p. 306-312.

Norberg, T.J., and Mount, D.I., 1985a, A new fathead minnow (Pimephales promelas) subchronic toxicity test: Environmental Toxicology and Chemistry, v. 4, p. 711-718.

Norberg, T.J., and Mount, D.E., 1985b, Diets for Ceriodaphnia reticulata life-cycle tests, in Cardwell, R.D., Purdy, R., and Bahner, R.C. eds., Aquatic toxicology and hazard assessment: Philadelphia, Seventh Symposium, American Society for Testing and Materials, Special Technical Publication 854, p. 42-52. 
Norberg-King, T.J., and Mount, D.I., eds., 1986, Validity of effluent and ambient toxicity tests for predicting biological impact, Skeleton Creek, Enid, Oklahoma: U.S. Environmental Protection Agency, Washington, D.C., EPA/600-8-86/002.

Odum, E.P., 1969, The strategy of ecosystem development: Science, v. 164, no. 3877 , p. 262-270.

Odum, E.P., 1971, Fundamentals of Ecology (3rd ed.): W.B. Saunders Co., Philadelphia, 574 p.

Ordog, Vince, 1982, Apparatus for laboratory algal bioassay: Internationale Revue Gesamten Hydrobiologie, v. 67, no. 1, p. 127-136.

Organization for Economic Co-operation and Development, 1985, The state of our environment, 1985: OECD Publications, Paris, 271 p.

Palmer, C.M., 1969, A composite rating of algae tolerating organic pollution: Journal of Phycology, v. 5, no. 1, p. 78-82.

Paparo, A.A., and Sparks, R.E., 1977, Rapid assessment of water quality using the fingernail clam, Musculium transversum, in Cairns, John, Jr., Dickson, K.L., and Westlake, G.F., eds., Biological monitoring of water and effluent quality: Philadelphia, American Society for Testing and Materials, Special Technical Publication 607, p. 96-109.

Payne, A.G., 1976, Application of the algal assay procedure in biostimulation and toxicity testing, in Middlebrooks, E.J., Falkenborg, D.H., and Maloney, T.E., eds., Biostimulation and nutrient assessment, Ann Arbor, Michigan, Ann Arbor Science, p. 3-27.

Payne, A.G., and Hall, R.H., 1979, A method for measuring algal toxicity and its application to safety assessment of new chemicals, in Marking, L.L., and Kimerle, R.A., eds., Aquatic Toxicology: Philadelphia, American Society for Testing and Materials, Special Technical Publication 667, p. 171-180.

Peltier, W.H., and Weber, C.I., eds., 1985, Methods for measuring the acute toxicity of effluents to freshwater and marine organisms (3rd ed.), U.S. Environmental Protection Agency 600/4-85/013.

Pennak, R.W., 1978, 2d ed., Fresh-water invertebrates of the United States: New York, John Wiley and Sons, 803 p.

Perez, K.T., and Morrison, G.E., 1985, Environmental assessments from simple test systems and a microcosm: comparisons of monetary costs, in Cairns, John, Jr., ed., Multispecies toxicity testing: New York, Pergamon Press, Society for Environmental Toxicology and Chemistry, Special Publication, p. 89-95. 
Perkins, J.L., 1983, Bioassay evaluation of diversity and community comparison indexes: Journal of the Water Pollution Control Federation, v. 55, no. 5, p. 522-530.

Pesch, C.E., and Hoffman, G.L., 1983, Interlaboratory comparison of a 28-day toxicity test with the polychaete Neanthes arenaceodentata, in Bishop, W.E., Cardwell, R.D., and Heidolph, B.B., eds., Aquatic toxicology and hazard assessment: Philadelphia, Sixth Symposium: American Society for Testing and Materials, Special Technical Publication 802, p. 482-493.

Pessah, Edward, and Cornwall, G.M., 1980, Use of toxicity tests in regulating the quality of industrial wastes in Canada, in Eaton, J.G., Parrish, P.R., and Hendricks, A.C., eds. Aquatic toxicology: Philadelphia, American Society for Testing and Materials, Special Technical Publication 707 , p. $130-141$.

Phillips, D.J.H., 1980, Quantitative Aquatic Biological Indicators; their use to monitor trace metal and organochlorine pollution: London, Applied Science Publishers, Ltd., 488 p.

Phipps, G.L., and Holcombe, G.W., 1985, A method for aquatic multiple species toxicant testing: acute toxicity of 10 chemicals to 5 vertebrates and 2 invertebrates: Environmental Pollution (Series A), v. 38, no. 2, p. 141157.

Plotkin, S., and Ram, N.M., 1984, Multiple bioassays to assess the toxicity of a sanitary landfill leachate: Archives of Environmental Contamination and Toxicology, v. 13, p. 197-206.

Poels, C.L.M., 1977, An automatic system for rapid detection of acute high concentrations of toxic substances in surface water using trout, in Cairns, John, Jr., Dickson, K.L., and Westlake, G.F., eds., Biological monitoring of water and effluent quality: Philadelphia, American Society for Testing and Materials, Special Technical Publication 607, p. 85-95.

Portier, R.J., 1985, Comparison of environmental effect and transformation of toxicants on laboratory microcosm and field microbial communities, in, Boyle, T.P., ed., Validation and predictability of laboratory methods for assessing the fate and effects of contaminants in aquatic ecosystems: Philadelphia, American Society for Testing and Materials, Special Technical Publication 865, p. 14-30.

Prater, B.L., and Anderson, M.A., 1977, A 96-hour bioassay of Otter Creek, Ohio: Journal of the Water Pollution Control Federation, v. 49, no. 11, p. 2,099-2,106.

Prescott, G.W., 1970, How to know the freshwater algae, (2d ed.): Dubuque, Iowa, Wm. C. Brown Co., 348 p. 
Qureshi, A.A., Flood, K.W., Thompson, S.R., Janhurst, S.M., Inniss, C.S., and Rokosh, D.A., 1982, Comparison of a luminescent bacterial test with other bioassays for determining toxicity of pure compounds and complex effluents, in Pearson, J.G., Foster, R.B., and Bishop, W.E., eds., Aquatic toxicology and hazard assessment: Philadelphia, Fifth Conference, American Society for Testing and Materials, Special Technical Publication 766, Philadelphia, p. 179-195.

Rawson, D.S., 1956, Algal indicators of trophic lake types: Limnology and Oceanography, v. 1 , no. 1 , p. 18-25.

Rheinheimer, G., 1974, Aquatic microbiology: London, John Wiley \& Sons, $184 \mathrm{p}$.

Ribo, J.M., and Kaiser, K.L.E., 1983, Effects of selected chemicals to photoluminescent bacteria and their correlations with acute and sublethal effects on other organisms: Chemoshpere, v. 12, no. 11/12, p. 1,4211,442 .

Rice, C.P., and White, D.S., 1987, PCB availability assessment of river dredging using caged clams and fish: Environmental Toxicology and Chemistry, v. 6, no. 4, p. 259-274.

Richey, J.E., 1979, Patterns of phosphorus supply and utilization in Lake Washington and Findlay Lake: Limnology and Oceanography, v. 24, no. 5, p. 906-916.

Roback, S.S., 1974, Insects (Arthropoda: Insecta), in Hart, C.W., and Fuller, S.L.H., eds., Pollution ecology of freshwater invertebrates: New York, Academic Press, p. 314-376

Robinson-Wilson, E.F., Boyle, T.B., and Petty, J.D., 1983, Effects of increasing levels of primary production on pentachlorophenol residues in experimental pond ecosystems, in Bishop, W.E., Cardwell, R.D., and Heidolph, B.B., eds., Aquatic toxicology and hazard assessment: Philadelphia, Sixth Symposium, American Society for Testing and Materials, Special Technical Publication 802, p. 239-251.

Roch, M., McCarter, J.A., Matheson, A.T., Clark, M.J.R., and Olafson, R.W., 1982, Hepatic metallothionein in rainbow trout (Salmo gairdneri) as an indicator of metal pollution in the Campbell River System: Canadian Journal of Fisheries and Aquatic Sciences, v. 39, no. 12, p. 1,596-1,601.

Rodgers, J.H., Jr., Cherry, D.S., Graney, R.L., Dickson, K.L., and Cairns, John, Jr., 1980, Comparison of heavy metal interactions in acute and artificial stream bioassay techniques for the Asiatic clam (Corbicula fluminea), in Eaton, J.G., Parrish, P.R., and Hendricks, A.C., eds., Aquatic toxicology: Philadelphia, American Society for Testing and Materials, Special Technical Publication 707, Philadelphia, p. 266-280. 
Sadler, K., 1983, A model relating the results of low pH bioassay experiments to the fishery status of Norwegian lakes: Freshwater Biology, v. 13, p. 453-463.

Salomons, Wim, and Forstner, Ulrich, 1984, Metals in the hydrocycle: Berlin, Springer-Verlag, 349 p.

Samoiloff, M.R., Schulz, S., Jordan, Y., senich, K., and Arnott, E., 1980, A rapid simple long-term toxicity assav for aquatic contaminants using the nematode Panagrellus redivivus: Canadian Journal of Fisheries and Aquatic Sciences, v. 37, no. 7, p. 1,167-1,174.

Sanders, B.M., and Jenkins, K.D., 1984, Relationships between free cupric ion concentrations in sea water and copper metabolism and growth in crab larvae: Biology Bulletin, v. 167, p. 704-712.

Sanders, B.M., Jenkins, K.D., Sunda, W.G., and Costlow, J.D., 1983, Free cupric ion acitivity in sea water: effects on metallothionein and growth in crab larvae: Science, v. 222, p. 53-55.

Schiewe, M.H., Hawk, E.G., Actor, D.I., and Krahn, M.M., 1985, Use of bacterial bioluminescence assay to assess toxicity of contaminated marine sediments: Canadian Journal of Fisheries and Áquatic Sciences, v. 42, p. $1,244-1,248$.

Schindler, D.W., 1985, The coupling of elemental cycles by organisms: evidence from whole-lake chemical perturbations, in Stumm, Werner, ed., Chemical processes in lakes: New York, Wiley-Intersci, p. 225-250, chap. 11.

Schuytema, G.S., Nelson, P.O., Malueg, K.W., Nebeker, A.V., Krawczyk, D.F., Ratcliff, A.K., and Gakstatter, J.H., 1984, Toxicity of cadmium in water and sediment slurries to Daphnia magna: Environmental Toxicology and Chemistry, v. 3, p. 293-308.

Selby, D.A., Ihnat, J.M., and Messer, J.J., 1985, Effects of subacute cadmium exposure on a hardwater mountain stream microcosm: Water Research, v. 19 , no. 5, p. 645-655.

Seyfried, P.L., and Horgan, C.B.L., 1985, Comparison of techniques for evaluating the effect of cadmium on Pseudomonas fluorescens, in Bahner, R.C., and Hansen, D.J., eds., Aquatic toxicology and hazard assessment: Philadelphia, Eighth Symposium, American Society for Testing and Materials, Special Technical Publication 891, p. 310-320.

Shriner, Carole, and Gregory, Tricia, 1984, Use of artificial streams for toxicological research: Critical Reviews in Toxicology, v. 13, no. 3, p. 253-281.

Slabbert, J.L., 1986, Improved bacterial growth test for rapid water toxicity screening: Bulletin of Environmental Contamination and Toxicology, v. 37, p. 565-569. 
Slabbert, J.L., and Grabow, W.O.K., 1986, A rapid water toxicity screening test based on oxygen uptake of Pseudomonas putida: Toxicity Assessment, v. 1 , no. 1 , p. 13-26.

Slooff, W., 1985, The role of multispecies testing in aquatic toxicology, in Cairns, John, Jr., ed., Multispecies toxicity testing: New York, Pergamon Press, Society for Environmental Toxicology and Chemistry, p. $45-60$.

Smith, V.H., 1982, The nitrogen and phosphorus dependence of algal biomass in lakes: an empirical and theoretical analysis: Limnology and Oceanography, v. 27 , no. 6 , p. 1,101-1,112.

Snarski, V.M., and Olson, G.F., 1982, Chronic toxicity and bioaccumulation of mercuric chloride in the fathead minnow (Pimephales promelas): Aquatic Toxicology, v. 2, p. 143-156.

Spehar, R.L., Tanner, D.K., Gibson, J.H., 1982, Effects of kelthane and pydrin on early life stages of fathead minnows (Pimephales promelas) and amphipods (Hyalella azteca), in Pearson, J.G., Foster, R.B., and Bishop, W.E., eds., Aquatic toxicology and hazard assessment: Philadelphia, Fifth Conference, American Society for Testing and Materials, Special Techinical Publication 766, p. 234-244.

Sprague, J.B., 1973, The $A B C^{\prime}$ s of pollutant bioassay using fish, in Cairns, John, Jr., and Dickson, K. L., eds., Biological methods for the assessment of water quality, American Society for Testing and Materials, Special Technical Publication 528, p. 6-30.

Sprague, J.B., 1976, Current status of sublethal tests of pollutants on aquatic organisms: Journal of the Fisheries Research Board of Canada, v. 33 , no. 9 , p. $1,988-1,992$.

Stay, F.S., Larsen, D.P., Katko, A., and Rohm, C.M., 1985, Effects of atrazine on community level responses in Taub microcosms, in Boyle, T. P., ed., Validation and predictability of laboratory methods for assessing the fate and effects of contaminants in aquatic ecosystems: Philadelphia, American Society for Testing and Materials, Special Technical Publication 865, p. 75-90.

Stegeman, J.J., Jr., 1978, Influence of environmental contamination on cytochrome P-450 mixed-function oxygenases in $\mathrm{fish}$ : implications for recovery in the Wild Harbor Marsh: Journal of the Fisheries Research Board of Canada, v. 35, no. 5, p. 668-674.

Stumm, Werner, Schwarzenbach, Rene, and Sigg, Laura, 1983, From environmental analytical chemistry to ecotoxicology--a plea for more concepts and less monitoring and testing: Angenandte Chemie, International Edition in English, v. 22, p. 380-389. 
Suloway, J.J., Schuller, R.M., and Griffin, R.A., 1981, Acute toxicity of leachates from coal gasification and liquefaction solid wastes to the fathead minnow, Pimephales promelas: Journal of Environmental Science and Health, v. A16, no. 4, p. 419-445.

Suter, G.W., II, 1983, Multispecies tests for environmental toxicology: Environment International, v. 9, p. 157-160.

Swartz, R.C., DeBen, W.A., Jones, J.K.P., Lamberson, J.O., and Cole, F.A., 1985, Phoxocephalid amphipod bioassay for marine sediment toxicity, in Cardwell, R.D., Purdy, R., and Bahner, R.C., eds., Aquatic toxicology and hazard assessment: Philadelphia, Seventh Symposium, American Society for Testing and Materials, Special Technical Publication 854, p. 284-307.

Swartz, R.C., Schults, D.W., Ditsworth, G.R., DeBen, W.A., and Cole, F.A., 1980, Sediment toxicity, contamination, and macrobenthic communities near a large sewage outfall, in Boyle, T.P., ed., Validation and predictability of laboratory methods for assessing the fate and effects of contaminants in aquatic ecosystems: Philadelphia, American Society for Testing and Materials, Standard Technical Publication 865, p. 152175 .

Tan, Barrie, Kilgore, M.V., Elam, D.L., Jr., Melius, Paul, and Schoor, W.P., 1981, Metabolites of benzo[a]pyrene in aroclor 1254-treated mullet, in Branson, D.R., and Dickson, K.I., eds., Aquatic toxicology and hazard assessment: Philadelphia, Fourth Conference, American Society for Testing and Materials, Special Technical Publication 737, p. 239-246.

Taub, F.B., 1985, Toward interlaboratory (round robin) testing of a standardized aquatic microcosm, in Cairns, John, Jr., ed., Multispecies toxicity testing: New York, Pergamon Press, Society for Environmental Toxicology and Chemistry, p. 165-186.

Taub, F.B., and Crow, M.E., 1978, Synthesizing aquatic microcosms, in Giesy, J.P., Jr., ed., Microcosms in ecological research: Washington, D.C., U.S. Department of Energy, Technical Information Center, Department of Energy Symposium Series 52, Conference 781101, p. 69-104.

Taub, F.B., Read, P.L., Kindig, A.C., Harrass, M.C., Hartmann, H.J., Conquest, L.L., Hardy, F.J., and Munro, P.T., 1983, Demonstration of the ecological effects of streptomycin and malathion on synthetic aquatic microcosms, in Bishop, W.E., Cardwell, R.D., and Heidolph, B.B., eds., Aquatic toxicology and hazard assessment: Philadelphia, Sixth Symposium, American Society for Testing and Materials, Special Technical Publication 802 , p. 5-25.

Taylor, M.J., 1985, Effect of diet on the sensitivity of Daphnia magna to linear alkylbenzene sulfonate, in Cardwell, R.D., Purdy, R., and Bahner, R.C. eds., Aquatic toxicology and hazard assessment: Philadelphia, Seventh Symposium, American Society for Testing and Materials, Special Technical Publication 854, p. 53-72. 
Ten Berge, W.F., 1978, Breeding Daphnia magma: Hydrobiologia, v. 59, no. 2 , p. $121-123$.

Thompson, K.A., Brown, D.A., Chapman, P.M., and Brinkhurst, R.O., 1982, Histopathological effects and cadmium-binding protein synthesis in the marine oligochaete Monopylephorus cuticulatus following cadmium exposure: Transactions of the American Microscopic Society, v. 101, no. 1, p. 1026.

Thompson, K.W., Hendricks, A.C., and Cairns, John, Jr., 1980, Acute toxicity of zinc and copper singly and in combination to the bluegill (Lepomis macrochirus): Bulletin of Environmental Contamination and Toxicology, v. 25, p. 122-129.

Thorp, J.H., and Gloss, S.P., 1986, Field and laboratory tests on acute toxicity of cadmium to freshwater crayfish: Bulletin of Environmental Contamination and Toxicology, v. 37, p. 355-361.

Thurston, R.V., Gilfoil, T.A., Meyn, E.L., Zajdel, R.K., Aoki, T.I., and Veith, G.D., 1985, Comparative toxicity of ten organic chemicals to ten common aquatic species: Water Research, v. 19, no. 9, p. 1,145-1,155.

Tietjen, J.M., and Lee, J.J., 1984, The use of free-living nematodes as a bioassay for estuarine sediments: Marine Environmental Research, v. 11, p. 233-252.

Trevors, J.T., Mayfield, C.I., and Inniss, W.E., 1982, Effect of sequence of exposure to chlorophenols in short-term bacterial bioassays: Archives of Environmental Contamination and Toxicology, v. 11, p. 203-207.

Trotter, D.M., and Hendricks, A.C., 1976, The use of stigeoclonium subsecundum (Chlorophyceae) as a bioassay organism II. The use of Stigeometers in a continuous flow system: Water Research, v. 10, p. 913-917.

Tsai, D.F., Welch, J, Chang, K.W., Shaeffer, J., and Cronin, L.E., 1979, Bioassay of Baltimore Harbor sediments: Estuaries, v. 2, p. 141-153.

Turbak, S.C., Olson, S.B., and McFeters, G.A., 1986, Comparison of algal assay systems for detecting waterborne herbicides and metals, Water Research, v. 20 , no. 1 , p. 91-96.

U.S. Environmental Protection Agency, 1986, Quality criteria for water 1986: EPA 440/5-86-001.

Van Coillie, R., Couture, P., and Visser, S. A., 1983, Use of algae in aquatic ecotoxicology, in Nriagu, Jerome O., ed., Aquatic toxicology: New York, John Wiley and Sons, chap. 18, p. 487-502. 
Van der Schalie, W.H., 1980, A new technique for automatic monitoring of fish ventilatory patterns and its possible uses in screening tests for chronic toxicity, in Eaton, J.G., Parrish, P.R., and Hendricks, A.C., eds., Aquatic toxicology: Philadelphia, American Society for Testing and Materials, Special Technical Publication 707, p. 233-242.

Vasseur, P., Ferad, J.F., Rast, C., and Larbaigt, G., 1984, Luminescent marine bacteria in acute toxicity testing, in Persoone, G., Jaspers, E., and Claus, C., eds., Ectoxicological testing for the marine environment: Belgium, State University of Ghent, v. 2, p. 381-398.

Voyer, R.A., and Heltshe, J.F., 1984, Factor interactions and aquatic toxicity testing: Water Research, v. 18, no. 4, p. 441-447.

Wallen, D.G. , and Botek, C.: 1984, Heterogeneous patterns of primary productivity in western Lake Erie: Verhandlungen Internationale Vereinigung Limnologie, v. 22, p. 495-503.

Wang, Wuncheng, 1986, Toxicity tests of aquatic pollutants by using common duckweed, Environmental Pollution (Series B), v. 11, p. 1-14.

Ward, H.B., and Whipple, G. C., 1959, Fresh-water biology: New York, John Wiley \& Sons, 1,248 p.

Westlake, G.F., and van der Schalie, W. H., 1977, Evaluation of an automated biological monitoring system at an industrial site, in Cairns, John, Jr., Dickson, K.L., and Westlake, G.F., eds., Biological monitoring of water and effluent quality: Philadelphia, American Society for Testing and Materials, Special Technical Publication 607, p. 30-37.

White, H.H., and Champ, M.A., 1984, The great bioassay hoax and alternatives, in Cairns, John, Jr., Dickson, K.L., and Maki, A.W., eds., Hazardous and industrial solid waste testing: Philadelphia, Second Symposium, American Society for Testing and Materials, Special Technical Publication 805, p. 299-312.

Wiesner, W., and Hinterleitner, S., 1980, Bulletin of Environmental Contamination and Toxicology, v. 25, p. 188-193.

Wilde, E.W., and Parrott, A.B., 1984, A simple inexpensive in situ method for assessing acute toxicity of effluents to fish: Water Research, v. 18, no. 6 , p. 783-785.

Williams, L.G., Chapman, P.M., and Ginn, T.C., 1986, A comparative evaluation of marine sediment toxicity using bacterial luminescence, oyster embryo and amphipod sediment bioassays: Marine Environmental Research, v. 19 [in press].

Winner, R.W., 1981, A comparison of body length, brood size and longevity as indices of chromic copper and zinc stresses in Daphnia magna:

Environmental Pollution (Series A), v. 26, no. 1, p. 33-37. 
Winner, R.W., and Farrell, M.P., 1976, Acute and chronic toxicity of copper to four species of Daphnia: Journal of the Fisheries Research Board of Canada, v. 33, no. 8, p. 1,685-1,691.

Woltering, D.M., 1983, Environmental influence on the response of aquatic laboratory ecosystems to a toxicant, in Bishop, W.E., Cardwell, R.D., and Heidolph, B.B., eds., Aquatic toxicology and hazard assessment: Philadelphia, Sixth Symposium, American Society for Testing and Materials, Special Technical Publication 802, p. 153-170.

Woltering, D.M., 1984, The growth response in fish chronic and early life stage toxicity tests: a critical review: Aquatic Toxicology, v. 5, p. $1-21$.

Wong, P.T.S., Chau, Y.K., and Patel, D., 1982, Physiological and biochemical responses of several freshwater algae to a mixture of metals, Chemosphere v. 11, no. 4 , p. 367-376.

Wong, S.L., 1984, Toxicity and water quality: a bioassay interpretation: Journal of Environmental Science and Health, v. A19, no. 3, p. 377-386.

Wright, D.A. and Frain, J.W., 1981, The effect of calcium on cadmium toxicity in the freshwater amphipod, Gammarus pulex (L.): Archives of Environmental Contamination and Toxicology, v. 10, p. 321-328.

Wuerthele, Mark, Zillich, John, Newton, Mike, and Fetterolf, Carlos, 1973, Descriptions of a continuous-flow bioassay laboratory trailer and the Michigan diluter, in Glass, G.E., ed., Bioassay techniques and environmental chemistry: Ann Arbor, Michigan, Ann Arbor Science Publishers, p. 345-354.

Yasuno, M., Sugaya, Y., and Iwakuma, T., 1985, Effects of insecticides on the benthic community in a model stream: Environmental Pollution (Series A), v. 38 , no. 1 , p. 31-43. 


\section{APPENDIX 1}

\section{TOXICITY-TEST PROCEDURES}

As indicated in this report, there are many biological species and different procedures used in toxicity testing. Detailed descriptions of the methods for each type of test are not given here, largely because they would only duplicate method descriptions that are readily available in the literature. Lists of specific publications that contain method descriptions for each of various test species and test types are given in Appendix tables 1 and 2 .

As an aid to readers who are unfamiliar with the toxicity testing approach in general, some concepts and common features of test procedures are discussed below.

Most toxicity-test procedures require enclosure of organisms, either in the laboratory or in the natural environment. Each enclosure functions as a simple microcosm to demonstrate an environmental effect. Functional, anatomical, and/or behavioral characteristics of test organisms are monitored simultaneously in each system. Changes of biological variables in experimental systems are compared with those of control systems. The experimental systems contain known concentrations of the test substance, varying from a concentration that is not expected to be bioeffective to a concentration that is equal to or greater than any concentrations that are likely to be found in nature. Such a test gradient is intended to bracket the minimum bioeffective concentration. The control systems contain no introduced toxicants, but all other conditions are identical (or as close as possible) to those of the experimental systems.

Ideally, any stress response by the test organisms will be attributable to the introduced toxicant rather than to other conditions of the experiment. Therefore, it is important to monitor properties such as temperature, dissolved oxygen, $\mathrm{pH}$, water hardness, and light, in the experimental and control media. To the extent possible, these conditions should be controlled to maximize: (1) their consistency among all enclosures, (2) their stability throughout the experiment, and (3) their representation of natural conditions.

Some species are amenable for use in virtually any tyre of toxicity test and their responses may be monitored by means of any of a variety of acute or chronic endpoints. For other species, the choices of test type and endpoints are more limited. Bacteria and phytoplankton, for example, cannot be used in acute lethality studies because of the impracticality of monitoring mortality in these microscopic organisms. Some population metabolic rates, such as bioluminescence or primary productivity, can be readily measured by standard methods, and are used as endpoints for species of microbiota.

Most applications of toxicity tests call for replication of experimental and control systems such that there are at least duplicate systems for each toxicant concentration tested, and for the controls. When macroscopic animals are used as test organisms, there are recommended limits to the number and biomass of organisms in each test chamber. These limits vary according to 
species and type of test, but for small invertebrates and early life stages of fish, they are on the order of $1-5 \mathrm{~g} / \mathrm{L}$ (live weight), and 10 organisms per chamber.

The duration of the test may vary from a few minutes for some bacterial tests, to several months for some chronic life cycle tests with invertebrates and $\mathrm{fish}$. Acute tests with invertebrates and $\mathrm{fish}$ commonly have specified durations of 48 or 96 hours. The length of the test, along with the requirements of the species, are important in determining whether or not to feed the test organisms during the test. The question of feeding presents somewhat of a dilemma. Lack of feeding may be stressful to the organisms and increase their susceptibility to toxicant effects (Nebeker and others, 1983). But feeding introduces another potential variable that could affect test results. Some of the references in Appendix Table 1, in particular those marked with an "S", contain considerable discussion of feeding techniques and effects.

There are various possible field microcosm or mesocosm configurations, including limnocorrals (large enclosures set in a lake or other water body), and experimental ponds. The general approach for these microcosm studies is similar to that of laboratory studies in that the biological effects of an introduced toxicant in experimental systems are measured against comparable biological activity in control systems. Field microcosm units are usually very large and they contain a multispecies community that closely replicates the natural community they represent. Because they are set in the natural environment, their physical and chemical conditions are not under the control of the experimenter, but they are likely to mimic conditions in the larger system.

Other field toxicity studies involve biological monitoring of organisms exposed to existing conditions in the natural environment, rather than to a test substance introduced by the researcher. The test organisms may be naturally occurring biota in their natural habitats, biota that colonize some artificial habitat emplaced in the natural system, or introduced species held in any type of enclosure that allows environmental exposure while preventing escape of the organisms. Monitoring is usually done at selected sites that represent a known or suspected gradient of toxicant concentrations. For example, sampling sites might be located upstream and at various distances downstream from a point source. Chemical analyses of water and sediments from the same sites and times provide complementary data that are useful for interpretation of the biomonitoring results. 
Appendix Table 1.--Partial list of publications containing detailed method descriptions for species-specific toxicity tests. Both acute and chronic test methods are applicable to invertebrate and fish species, and are indicated by " $A$ " and "C", respectively. An "S" indicates description of special tools or auxiliary procedures that can facilitate or modify the method. Special feeding techniques or requirements are included in the special procedures.

BACTERIA

Photobacterium phosphoreum

Others

\section{Reference}

Bitton, 1983

Bulich, 1979

Burton \& Lanza, 1985

Coleman \& Qureshi, 1985

Dezwart \& Slooff, 1983

Dutka \& Kwan, 1981

Dutka \& Kwan, 1982

Dutka \& others, 1983

Freeman, 1986

McFeters \& others, 1983

Schiewe \& others, 1985

Seyfried \& Horgan

Slabbert \& Grabow, 1986

Vasseur \& others, 1984

PROTOZOANS

$\begin{array}{ccc}\mathrm{X} & & \mathrm{X} \\ \mathrm{X} & & \\ \mathrm{X} & \mathrm{X} & \\ \mathrm{X} & & \mathrm{X} \\ \mathrm{X} & & \mathrm{X} \\ \mathrm{X} & & \mathrm{X} \\ \mathrm{X} & & \mathrm{X} \\ \mathrm{X} & & \mathrm{X} \\ \mathrm{X} & & \mathrm{X} \\ \mathrm{X} & & \\ & & \mathrm{X} \\ & & \mathrm{X}\end{array}$

$\mathrm{X}$ $x$

$\mathrm{X}$

$x$

$\mathrm{X}$

$x$

$X$
$X$

$x$

\section{Chilomonas Tetrahymena} paramecium pyriformis

\section{Reference}

Honig \& others, 1980

Slabbert \& Morgan, 1982
C

C 
Appendix Table 1.--Partial list of publications containing detailed method descriptions for species-specific toxicity tests--Continued

GREEN ALGAE

Selenastrum Scenedesmus

capricornutum quadricauda others

\section{$\underline{\text { Reference }}$}

Aly \& others, 1984

$\mathrm{X}$

Bartlett \& others, 1974

Christensen \& others, 1979

Devries \& Hotting, 1985

Freeman, 1986

Gaur \& Kumar, 1986

Giddings \& others, 1983

Joubert, 1983

Kuivasniemi \& others, 1985

Miller \& others, 1978

Ordog, 1982

Payne \& Hall

Trotter \& Hendricks, 1976

van Coillie \& others, 1983

$\begin{array}{lll} & \mathrm{X} & \\ \mathrm{X} & & \\ \mathrm{X} & & \\ \mathrm{X} & & \\ \mathrm{X} & & \\ \mathrm{X} & & \mathrm{X} \\ \mathrm{X} & & \mathrm{X} \\ \mathrm{X} & \mathrm{X} & \mathrm{X} \\ \mathrm{X} & & \mathrm{X} \\ \mathrm{X} & & \mathrm{X} \\ \mathrm{X} & \mathrm{X} & \\ \mathrm{X} & & \end{array}$

MACROPHYTES

Reference $\quad \frac{\text { Lemna }}{\underline{\text { minor }}} \quad \underline{\text { Eichhornia }}$ others

Bishop \& Perry, 1981

Hartman \& Martin, 1985

Kay \& others, 1984

King \& Coley, 1985

Lockhart \& others, 1983

Wang, 1986

$\mathrm{X}$

$\mathrm{x} x$

$\mathrm{x}$

$\mathrm{X}$

$\mathrm{X}$

OLIGOCHAETES

Reference

Limnoldrilus Tubifex

hoffmeisteri tubifex others

American Public Health

Association \& others, 1985

Bailey \& Liu, 1980

Chapman \& Mitchell, 1986

Chapman \& Brinkhurst, 1984

Chapman \& others, 1982a

Chapman \& others, 1982b

$\begin{array}{lll}\text { AC } & \text { AC } & \\ & & \text { A } \\ & & \text { A } \\ \text { A } & \text { A } & \text { A } \\ \text { A } & \text { A } & \\ \text { A } & \text { A } & \end{array}$


Appendix Table 1.--Partial list of publications containing detailed method descriptions for species-specific toxicity tests--Continued

\section{CLADOCERANS}

Reference

\section{Daphnia Ceriodaphnia} nagna spp.
Other

Daphnia
Adams and Heidolph, 1985

APHA \& others, 1985

Barera \& Adams, 1983

Bowman \& others, 1981

Buikema \& others, 1980

Cowgill \& others, 1985

Geiger \& others, 1980

Gersich \& Mayes, 1986

Goulden \& others, 1982

Horning \& Weber, 1985

Jop \& others, 1986

Keating, 1985

LeBlanc \& others, 1983

McKnaught \& Mount, 1985

Mount \& Norberg, 1984

Nebeker, 1982

Norberg \& Mount, 1985

Peltier \& Weber, 1985

Taylor, 1985
C

AC

A

A

ACS

$\mathrm{S}$

A

ACS

C

C

C

AC

C

S

A

$\mathrm{S}$
$\mathrm{S}$

A

AC

S

c

$s$

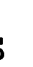

OTHER CRUSTACEANS

Reference Amphipods Decapods Others

American Public Health

Association \& others, 1985 AC

Abel, 1980

Abel \& Garner, 1986

Arthur, 1980

Bowman \& others, 1981

Buikema \& others, 1980

Martin \& Holdich, 1986

Prater \& Anderson, 1977

Swartz \& others, 1985

Thorp and Gloss, 1986

Graney \& Geisy, 1987

A

A

AC

A

A

AC

A 
Appendix Table 1.--Partial list of publications containing detailed method descriptions for species-specific toxicity tests--Continued

INSECTS
Reference $\quad \frac{\text { Chironomidae }}{\text { spp. Hexagenia }}$ others

Cushman \& McKamey, 1981

Anderson, 1980

A

Batac-Catalan \& White, 1983

Bowman \& others, 1981

Darville \& Wilhm, 1984

Fremling \& Mauck, 1980

Prater \& Anderson, 1977

Nebeker, Cairns, \& Wise, 1984 A

C

C

ACS

A

A

Corbicula Other

spp. Bivalves

Harrison \& others, 1984

A

Dauble \& others, 1985

Paparo \& Sparks, 1977

C

Rodgers \& others, 1980

A

A

NEMATODES

Reference

Tietjen \& Lee, 1984

Samoiloff \& others, 1980

Haight \& others, 1982 
Appendix Table 1.--Partial list of publications containing detailed method descriptions for species-specific toxicity tests--Continued

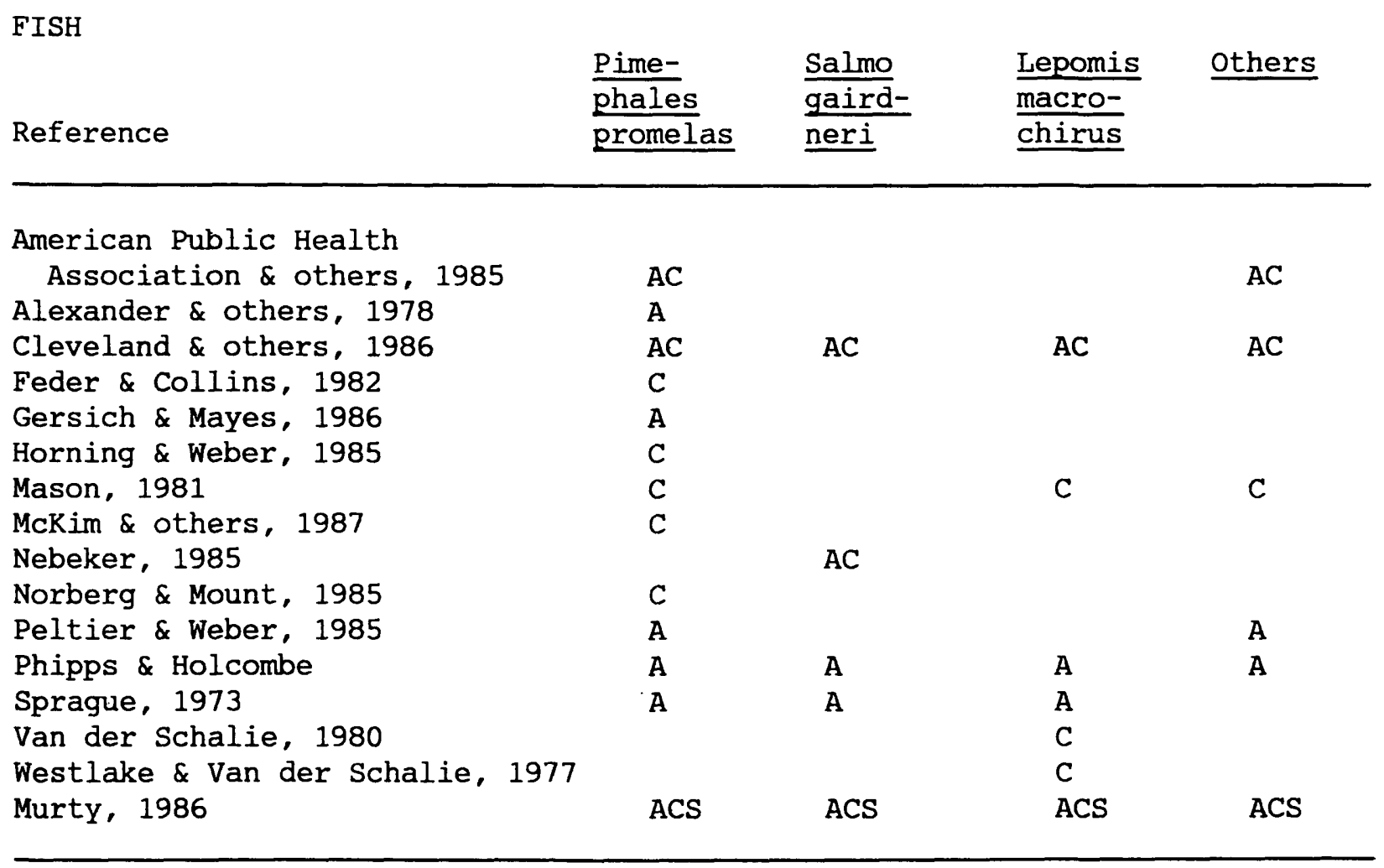


Appendix Table 2.--Partial list of references with detailed method descriptions for different toxicity test types

SMALL LABORATORY ENCLOSURES (Acute or Chronic)

Reference Static Flow-Through

Alexander \& others, 1978

$\mathrm{X}$

$\mathrm{x}$

American Public Health

Association \& others, 1985

Bishop \& Perry, 1981

Bowman \& others, 1981

Brungs, 1973

Buikema \& others, 1980

Geiger \& others, 1980

Gersich \& Mayes, 1986

Hansen \& Tagatz, 1980

Horning \& Weber, 1985

Mason, 1981

Meador \& others, 1984

Mount \& Brungs, 1967

Mount \& Norberg, 1984

Nebeker, 1982

Norberg \& Mount, 1985

Nebeker \& others, 1984

Peltier \& Weber, 1985

Phipps \& Holcombe, 1985

Sprague, 1973

Thurston \& others, 1985

Brungs, 1973

Birge \& others, 1979

Iwan \& Cella, 1981

Gruber \& others, 1980

Meadow \& others, 1984

Wuerthele \& others, 1973

$\mathrm{X}$

$\mathrm{X}$

$\mathrm{X}$

$\mathrm{X}$

$\mathrm{X}$

$\mathrm{X}$

X

$\mathrm{X}$

$\mathrm{x}$

$\mathrm{X}$

$\mathrm{x}$

$\mathrm{X}$

$\mathrm{X}$
$\mathrm{X}$

X

$\mathrm{x}$

$\mathrm{X}$

$\mathrm{X}$

$\mathrm{X}$

$\mathrm{x}$

$\mathrm{X}$

$x$

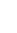

$\mathrm{X}$

$X$
$X$
$X$
$X$
$X$
$X$
$X$
$X$
$X$
$X$ 
Appendix Table 2.--Partial list of references with detailed method descriptions for different toxicity test types--Continued

LABORATORY MICROCOSMS

Reference

Aquaria

Artificial

streams

Adams, V. D. \& others, 1985

Black \& others, 1973

Giddings, 1986

Giddings \& Franco, 1985

Graney \& others, 1984

Hamela \& Kollig, 1985

Hansen \& Tagatz, 1980

Harass \& Taub, 1985

Hedtke, 1984

Honig \& Buikema, 1980

Levy \& others, 1985

Portier, 1985

Rodgers \& others, 1980

Shriner \& Gregory, ?

Stay \& others, 1985

Taub \& Crow, 1978

Taub \& others, 1983

Westlake \& Van der Schalie, 1977

Yasuno \& others, 1985

$\mathrm{X}$

$\mathrm{X}$

$\mathrm{X}$

$\mathrm{X}$

$\mathrm{x}$

$\mathrm{X}$

$\mathrm{X}$

$\mathrm{X}$

$\mathrm{X}$

$\mathrm{X}$

$\mathrm{X}$

$x$

$\mathrm{X}$

$\mathrm{X}$

$\mathrm{X}$

$\mathrm{X}$

$\mathrm{X}$

Experimental ponds and Limno-

streams corrals others
$\mathrm{X}$

$\mathrm{X}$
Reference

DeNoyelles \& Kettle, 1985

Giddings \& Franco, 1985

Hedtke \& Arthur, 1985

Herman \& others, 1986

Kaushik \& others, 1985

Kaushik \& others, 1986

Robinson-Wilson \& others, 1983

Marshall \& Mellinger, 1980

Wilde \& Parrott, 1984
$\mathrm{X}$

$\mathrm{X}$

$\mathrm{X}$

$\mathrm{x}$ 
Appendix Table 2.--Partial list of references with detailed method descriptions for different toxicity test types--Continued

FIELD INCUBATION PROCEDURES

Reference

Artificial Caged

subtrates Organisms

Beak \& others, 1973

Foe \& Knight, 1987

Rice \& White, 1987

Perkins, 1983

Leland \& Carter, 1985

$\mathrm{X}$

$\mathrm{x}$

$x$

$\mathrm{X}$

$\mathrm{X}$

SEDIMENT TESTS

Reference

LeBlanc \& Suprenant, 1985

Long \& Chapman, 1985

Malueg \& others, 1984

Prater \& Anderson, 1977

Schiewe \& others, 1985

BIOCHEMICAL AND PHYSIOLOGICAL TESTS

Reference

Bitton, 1983

Graney \& Geisy, 1987

Hinton \& others, 1973

Katz, 1979

Neff, 1985

Wong \& others, 1982 
Appendix Table 2.--Partial list of references with detailed method descriptions for different toxicity test types--Continued

ELECTRONIC AND COMPUTERIZED MONITORING

Reference

Besch \& others, 1977

Fisher \& others, 1982

Gruber \& Cairns, 1981

Gruber \& others, 1980

Kleerekoper, 1977

Maki, 1979

Morgan, 1977

Poels, 1977

Van der Schalie, 1980 